\title{
Paths of Development in Bolivia: Contradictions of the Proceso de Cambio
}

by

\author{
Kirsten Francescone
}

A thesis submitted to the Faculty of Graduate and Postdoctoral Affairs in partial fulfillment of the requirements for the degree of

Master of Arts

in

Political Economy

Carleton University

Ottawa, Ontario

(C) 2012, Kirsten Francescone 
Library and Archives

Canada

Published Heritage

Branch

395 Wellington Street

Ottawa ON K1A ON4

Canada
Bibliothèque et

Archives Canada

Direction du

Patrimoine de l'édition

395 , rue Wellington

Ottawa ON K1A ON4

Canada
Your file Votre référence

ISBN: $978-0-494-93627-6$

Our file Notre référence

ISBN: $978-0-494-93627-6$
NOTICE:

The author has granted a nonexclusive license allowing Library and Archives Canada to reproduce, publish, archive, preserve, conserve, communicate to the public by telecommunication or on the Internet, loan, distrbute and sell theses worldwide, for commercial or noncommercial purposes, in microform, paper, electronic and/or any other formats.

The author retains copyright ownership and moral rights in this thesis. Neither the thesis nor substantial extracts from it may be printed or otherwise reproduced without the author's permission.
AVIS:

L'auteur a accordé une licence non exclusive permettant à la Bibliothèque et Archives Canada de reproduire, publier, archiver, sauvegarder, conserver, transmettre au public par télécommunication ou par l'Internet, prêter, distribuer et vendre des thèses partout dans le monde, à des fins commerciales ou autres, sur support microforme, papier, électronique et/ou autres formats.

L'auteur conserve la propriété du droit d'auteur et des droits moraux qui protege cette thèse. $\mathrm{Ni}$ la thèse ni des extraits substantiels de celle-ci ne doivent être imprimés ou autrement reproduits sans son autorisation.
In compliance with the Canadian Privacy Act some supporting forms may have been removed from this thesis.

While these forms may be included in the document page count, their removal does not represent any loss of content from the thesis.
Conformément à la loi canadienne sur la protection de la vie privée, quelques formulaires secondaires ont été enlevés de cette thèse.

Bien que ces formulaires aient inclus dans la pagination, il n'y aura aucun contenu manquant. 


\section{Abstract}

This study seeks to explore and challenge Bolivia's Movimiento al Socialismo's (MAS) proceso de cambio by accessing the possibilities and limitations in their strategy for agricultural development. As a product of seven months of engaged fieldwork methods, I examine the MAS' most recent agricultural policy (Ley de la Revolución Productiva Comunitaria Agropecuaria (LRPCA)) and follow two interconnected political mobilizations, the mobilizations against the LRPCA and the infamous "TIPNIS" highway-project. I argue that the MAS' agricultural strategy reflects the larger political economic tendencies of the government across industries. The LPRCA serves to benefit and promote the expansion of the agro-industry further solidifying its position as a primary-resource producing nation. This failure to radically re-organize production has contributed to the increasing conflict and tension within and between Bolivia's popular sectors. I conclude by examining the limitations and possibilities for cross-sectorial political alliances that are looking to reclaim their vision of the proceso de cambio and alter the political-economic landscape of Bolivia. 


\section{Resumen}

Esta investigación trata entender y cuestionar el llamado "proceso de cambio" conducido por el gobierno del Movimiento al Socialismo en Bolivia, evaluando las posibilidades así como limitaciones de su estrategia para el desarrollo agrícola. Como producto de siete meses de trabajo de campo, examino la actual legislación agrícola (Ley de la Revolución Productiva Comunitaria Agropecuaria (LRPCA)) y hago seguimiento a dos movilizaciones interconectadas: la movilización contra los transgénicos y el famoso conflicto del TIPNIS. Arguyo que la estrategia agrícola del MAS refleja las tendencias estructurales del actual gobierno para la industria. La (LRPCA) sirve para beneficiar y promover la expansión de la agro-industria y resulta solidificando la posición neo-colonial que mantenga a Bolivia como nación productora de materias primas. La decisión política por el MAS de no re-organizar radicalmente la producción agrícola ha contribuido al crecimiento de los conflictos y tensiones dentro de los sectores populares. En la conclusión examino las limitaciones y posibilidades para las alianzas entre sectores que, en alguna medida, están re-posicionándose frente a llamado "proceso de cambio". 


\section{Acknowledgements}

I would like to acknowledge the guidance and support I have received from my supervisor for this project, Justin Paulson, whose intellectual and emotional support cannot be understated and will continue to shape my understanding of the world. I would also like to thank the following people: Susan Spronk, Cristina Rojas and Peter Gose for their insightful and much appreciated comments and criticisms of this work. I would also like to extend particular recognition to Donna Coghill, the administrator of the department of Political Economy at Carleton University for her comments, criticisms, encouragement, and labour that made the completion of this thesis possible.

The Centro de Documentacion e Informacion de Bolivia (CEDIB) was an invaluable wealth of resources, documents and literature over the course of my fieldwork and became my home base for debate and discussion regarding this project. I learned a lot from their investigators and resource aids and their library has an incredible collection of works that cannot be found elsewhere. In particular Georgina Jimenez, Pablo Villegas, Vladimir Diaz, Rosemary Amils, and Jorge Campanini were extremely beneficial to my intellectual development and growth, and insightful for my understanding of the Bolivia's past and present history.

I would also like to acknowledge the invaluable contribution of all of the people with whom I had conversations about this study, especially the women leaders of CONAMAQ who allowed me to stay with them in the Vigilia San Francisco over the course of their struggle. Their time and labour was greatly appreciated, and significantly 
contributed to the ways in which I framed and understood the issue, and Bolivia more generally. I learned more about the politics of struggle and mobilization from listening and debating with those involved in the moments I describe than I could have hoped for.
Also this work could not have been completed without the funding support of the Social Science and Humanities Research Council (SSHRC) and Ontario Graduate Scholarship (OGS) funding opportunities that enabled me to travel to Bolivia and return there the following year for follow-ups. 


\section{Table of Contents}

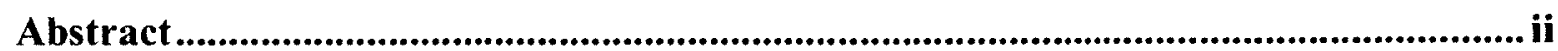

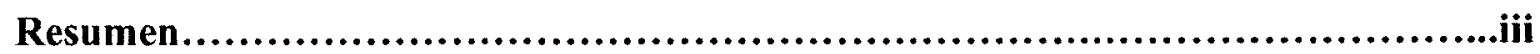

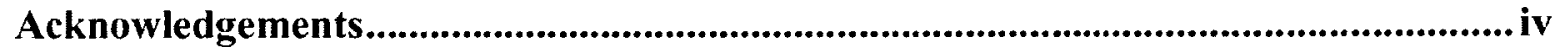

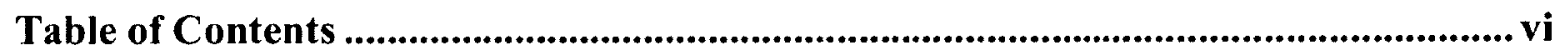

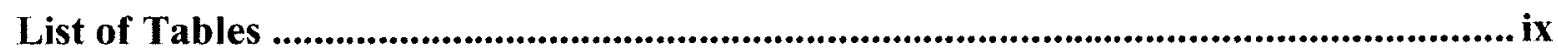

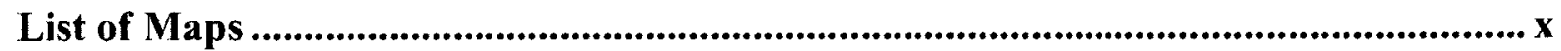

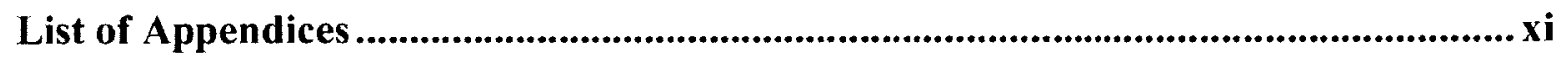

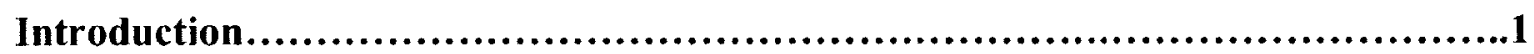

\section{Chapter 1: Community Production and the Development of Capitalist Agricultural}

Production.................................................................11

1.1 Spanish colonialism, liberation and the colonial destruction of community ................13

1.2 The Agrarian Reform and the 'Rolling-Out' of capitalism .......................... 20

1.3 Land and the years following the Agrarian Reform .............................. 28

$1.4 \mathrm{Re}$-construction of the community and the possibilities for agricultural production...........32

\section{Chapter 2: The Ley de La Revolucion Productiva and the Contradictions of}

Capital.......................................................................36

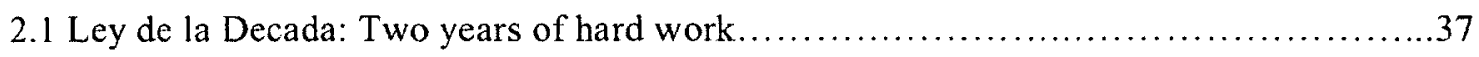

2.2 The Ley de la Revolucion Productiva Communitaria Agropecuaria: Consultation,

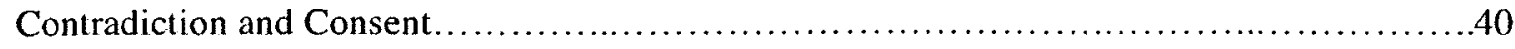

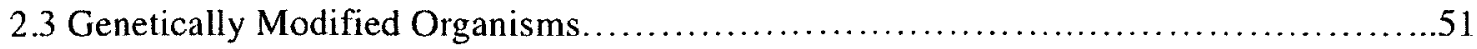

2.4 Genetically modified Organisms in Bolivia: Past and Present......................52 
3.1 The Campesino - Indigena Question: pequeños productores, economía plural, and the

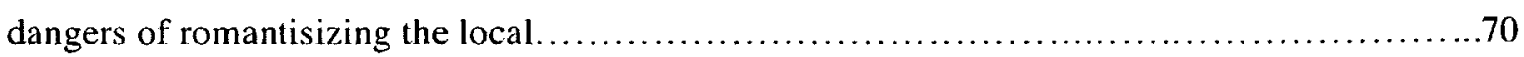

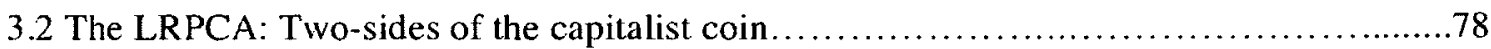

Chapter 4: The Complexities between "the State" and "Civil Society" ..............82

4.1 Popular (?) political participation and the Asamblea Constituyente ......................82

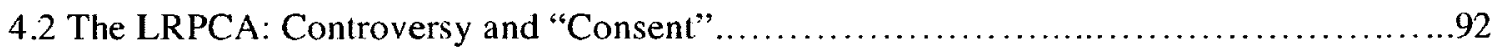

4.3 ;Esto es el pueblo, el pueblo no es pagado! .....................................96

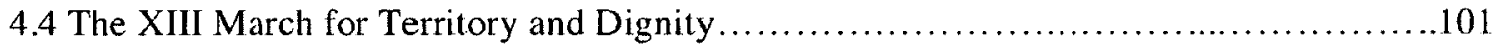

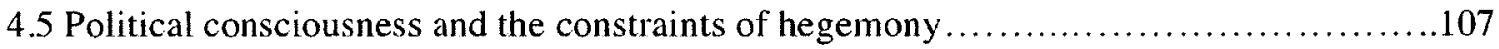

Chapter 5: Strategic Alliances and a Politics of Possibility.......................111

5.1 Organic intellectuals and the production of practical knowledge $\ldots \ldots \ldots \ldots \ldots \ldots \ldots \ldots \ldots$

5.2 Criticism, debate and the Intellectual and Urban Class ............................119

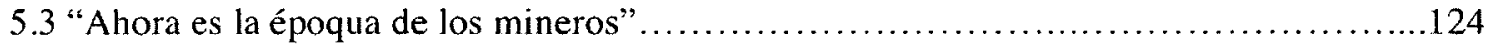

5.4 Popular sector alliances and the re-ignition of the national popular and indigenous sectors

$5.5 \mathrm{El}$ "como" y la recuperacion del proceso de Cambio." Herein lies the politics of possibility

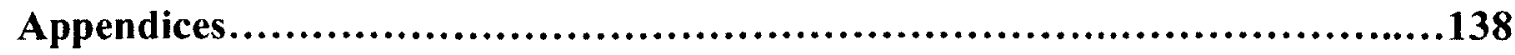

Appendix A: Abbreviations......................................................... 138

Appendix B: Methodology ................................................ 140 
References.....................................................................143 


\section{List of Tables}

Table I: Agricultural Production in Bolivia.....................................46

Table II: Top Five Agricultural Exports/Imports in Bolivia......................47

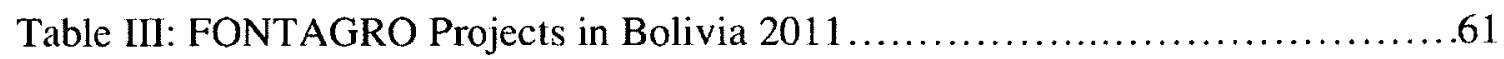




\section{List of Maps:}

Map I: Physical Map of Bolivia ..............................................

Map II: Forest Coverage in 1986 and 2005, Santa Cruz .........................63

Map III: TIPNIS Territory and Projected Highway Project.......................... 98 


\section{List of Appendices}

Appendix A: Abbreviations .................................................. 138

Appendix B. Methodology .................................................. 140 


\section{Introduction}

Bolivia is a landlocked country situated in central South America (See Map I). Given its geographic positioning and geological composition, it has three distinct climate zones which are roughly divided as the highland (red-brown), valley (yellow), and lowland (green) region making its agricultural production both varied and diversified and the modes of production equally so. Its geological variation has also contributed to intense and highly concentrated zones of mineralization, which, since the arrival of the Spanish, contributed to maintaining imperialist and neo-imperialist economic and political dependency for the extraction and exportation of raw materials. Agriculture in Bolivia has consistently been tied to the boom and bust cycles of the mining industry, due to its necessity for maintaining subsistence for the miners. ${ }^{1}$

\section{Map I: Physical Map of Bolivia}

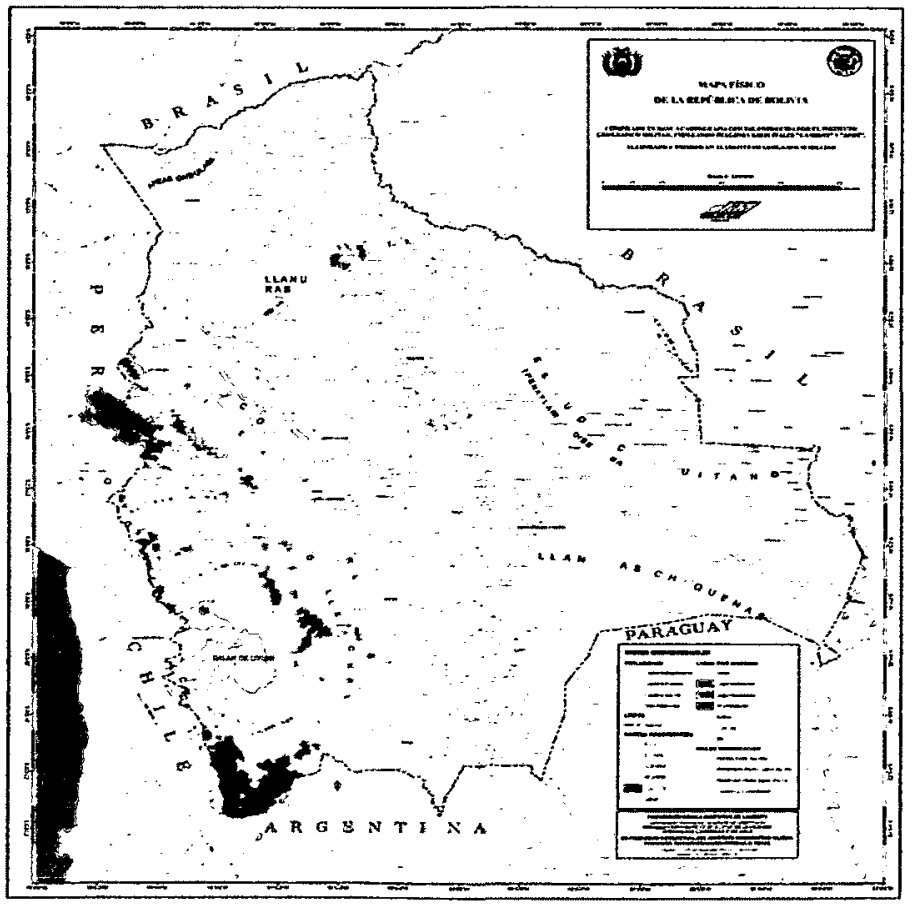

As a result of hundreds of years of colonial and neo-colonial oppression, Bolivians are also known for their unrelenting resistance. From indigenous uprisings against land liberalization

\footnotetext{
${ }^{1}$ Herbert Klein, Historia de Bolivia (La Paz: Libreria Editorial G.U.M, 2000).
} 
resistance. From indigenous uprisings against land liberalization policies, campesino insurgency leading up to the popular revolution in ' 52 , clandestine mining resistance during the dictators and the large popular and middle-class uprisings against neoliberalization in the $90 \mathrm{~s}$ and 2000 s, Bolivians provide not only an example but also a case of hope for struggle internationally.

In fact as many have argued, the national-popular and indigenous uprising that began to re-surface in the 90's with the lowland indigenous uprisings and the resurgence of the national-popular movements in the 2000s led to the development of the popular assemblies, the creation of the Pacto de Unidad, ${ }^{2}$ and the propulsion of the election of the Movimiento al Socialismo (MAS) and Evo Morales in 2005. ${ }^{3}$ The generalized movements that lead up to the expulsion of Gonzalez Sanchez de Lozado were nationwide, with key indigenous uprisings emerging from the Junta Vecinales in the political capital of La Paz.

Following their election, the MAS under the leadership of Morales has been touted as one of the emerging "Pink Tide" or $21^{\text {st }}$ Century Socialist governments of Latin America, and

\footnotetext{
${ }^{2}$ The Pacto de Unidad is a collection of indigenous and campesino organizations that, posterior to its creation, has served to participate both in the production of legislation, but also in organizing mass mobilizations prior to, and continuing with the election of the MAS. It originally was composed of the Consejo Nacional de Ayllus Markas Qullasuyu (CONAMAQ), the Confederación Sindical Única de Trabajadores (CSUTCB), Bartolina Sisa (CNMCIOB-BS), Confederación Indigena de Bolivia (CIDOB), Interculturales y el Movimiento Sin Tierra (MST). See Pablo Regalsky, "Las paradojas del proceso constituyente boliviano," Accessed August 12, 2011: www.constituyentesoberana.org; Chavez and Mokrani, Los Movimientos Sociales en la Asemblea Constituyente: Hacia la reconfiguracion de la politica (Buenos Aires: CLASCO, 2009).

${ }^{3}$ See Jim Shultz and Melissa Draper, Dignity and Defiance: Stories from Bolivia's Challenge to Globalization (Los Angeles: University of California Press, 2008); Nancy Postero, Now we are Citizens: Indigenous Politics in Postmulticultural Bolivia (California: Stanford University, 2008); and Mark Goodale, "Reclaiming Modernity: Indigenous cosmopolitanism and the coming of the second revolution of Bolivia," American Ethnologist, 33(2006): 634-649.
} 
has been labeled as a symbol of hope and change for the global revolutionary Left. ${ }^{4}$ With the approval of the New Political Constitution of the State by the MAS government, and the MAS' relentless and somewhat radical denunciations of capitalism and imperialism, the Morales government has most certainly emerged in the international arena as an anticapitalist force to be reckoned with.

Simultaneously and somewhat paradoxically, however, neo-colonial financial institutions like the World Bank and the International Monetary Fund have also appraised Bolivia under Morales. ${ }^{5}$ The MAS has also repeatedly announced investing energy into strengthening their relationship with the United States and despite claims from the MAS administration of the nationalization of the hydrocarbon and mining industries, Bolivian and foreign researchers have argued things have not happened as neatly as the MAS is claiming. Further tensions continue to emerge within the popular classes that once united, overthrew the neoliberal governments in the early 2000 s, and whose "October agenda" in 2003 demanded the expulsion of private enterprise's ransacking of the country's natural resources.

\footnotetext{
${ }^{4}$ Heinz Dieterich, "The Advance of 21 st Century Socialism in Latin America and Europe," The 4th Forum of the World Association for Political Economy, (2010): 143-147.

${ }^{5}$ Jeff Webber, "Revolution against "progress": the TIPNIS struggle and class contradictions in Bolivia." International Socialism 133(2012).
} 
On August $6^{\text {th }}, 2012$ in front of the Bolivian parliament, Evo Morales announced his economic plan for the country for 2025 . In the country's anniversary speech he claimed that:

...llegar al Bicentenario y que todo nuestro pueblo esté con servicios básicos (...) yo digo el 2025, de rincón a rincón, agua potable, luz y telefonía para el pueblo boliviano. El 2025: autosuficiencia alimentaria con soberanía y aquí hago un llamado a todos los hermanos del campo. ${ }^{6}$

In fact, food sovereignty has been on the recent Morales discursive agenda since the release of the Ley de la Revolucion Productiva Comunitaria Agropecuaria (LRPCA) in 2011. This years meeting of the OAS even took place in Cochabamba, with the main focus of the meeting being "food security with sovereignty." His emphasis on the "hermanos del campo" is also significant for our purposes, in that, discursively, Morales argues that small-scale community production is the key to obtaining food sovereignty.

The Via Campesina claims food sovereignty must necessarily include the following conditions: local food production, protection from food importations, sustainable agricultural production and biodiversity, just labour conditions and access to healthy food. ${ }^{7}$ However, as we will see later on, while discursively encouraging "food sovereignty", and "local" production, the Morales administration is simultaneously promoting the expansion of agro-industry, particularly in the production of cash crops. This contradiction is leading to popular unrest, and increased inter-sectorial conflicts.

\footnotetext{
${ }^{6}$ Baldwin Montero, "Evo fija 3 metas para el 2025." La Razon, August 7, 2012.

7 Paul Nicholson and Nicole Delforge, "Via Campesina: Responding to global systemic food crisis," Development 51(2008): 457.
} 
Josue de Castro, Brazilian doctor and economist, in 1959 reveals a question that still maintains central relevance, some 50 years later. In his book entitled Geopolitica del Hambre he argues that hunger is not in fact caused by lack of production of food, if not caused by the politics of distribution of food, a politic that is both capitalist and imperialist. ${ }^{8}$ Despite the fact that food production has risen significantly over the past century, hunger has maintained its presence in the global landscape. Yet, according to the ways in which hunger was framed at this years OAS in Cochabamba, and the continued insistence of the MAS administration on industrialization, increased food production via industrialization is Bolivia's only chance for eliminating hunger.

Considering the increased international focus on the MAS administration in recent years, and the ways in which it has served as a symbol of hope for progressive scholars and activists globally, it is important to delve into what appear to be contradicting tendencies surrounding a theme that is central to any progressive re-organization of political and economic policies: agricultural production.

This investigation seeks then, to engage in a historical materialist's analysis of the political economy of agricultural production in Bolivia under the Morales government. Under such a broad topic of exploration this project addresses questions surrounding communitarian socialism, as well as the relationship between the state and social movements. Finally, the challenges, if any, that the MAS presents to capitalist and

\footnotetext{
${ }^{8}$ Josue de Castro, Geopolítica del Hambre: Ensayo sobre los problemas alimentarios y demográficos del mundo (Buenos Aires: Solar Hachette, 1963).
} 
imperialist powers of today as they materialize in agricultural production in light of a growing food crisis nationally and globally.

For Marx, historical materialism provides us with the tools that prevent the dangers of generalization, determinism and linear knowledge production to analyze the ways in which in "moments", times of "political conjuncture", or "crisis" can (and must) be analyzed alongside and within the relations of production, in our present case, capital. ${ }^{9}$ The core of the dialectic then, for studies in social movements, cannot be the significance of that particular moment of crisis and its' necessary movement towards revolution, but rather the spaces that moment produces for dialectical processes to be battled out, to be contested and negotiated, and then to continue producing. This is what allows for the uncertainty but also the possibilities of political mobilizations.

Gramsci adds that moments of crisis reveal the ways in which the political and economic terrain of struggle is organized; and then how civil society, elite groups, members of the proletariat and working classes and intellectuals work out or battle their way through conflicting moments in time. Finally, moments of crisis reveal how social relations become re-organized as a result:

...the crisis [of hegemony] creates situations that are dangerous in the short run since the various strata of the population are not all capable of orienting themselves equally swiftly, or of reorganizing with the same rhythm. The traditional ruling class, which has numerous trained cadres, changes men and programmes and, with greater speed than is achieved by the subordinate classes, reabsorbs the control that was slipping from its grasp. ${ }^{10}$

\footnotetext{
${ }^{9}$ Karl Marx, The Grundrisse Notebooks (New York: Penguin Classics, 2005).

${ }^{10}$ Antonio Gramsci, Selections from the Prison Notebooks, ed. Smith and Hoare (New York: International Publishers, 1971), 210.
} 
Moments provide us with windows through which we can observe the capitalist dialectic. Their importance not only lies in their centrality of moments of revolution, but also as moments that need to be documented and noted for the battles to come which produces knowledge that is as much historically relevant, as it is politically practical.

In attempts to revive old discussions about agricultural production in light of decades of failed agricultural reforms within the industrial capital paradigm, ${ }^{11}$ this study attempts to reveal the dangers and possibilities of the MAS' current agricultural agenda. Bolivia has a recent historical experience with the ways in which agricultural industrialization failed to eliminate hunger, while increasing economic dependency at the behest of foreign capital interests (something we will see in Chapter 1). With recent global technological changes like GMO seeds and patented technology, the risks are even greater for the Bolivia of today, a risk that will continue to be born by the popular classes, those most vulnerable to rising food prices, volatile markets and displacement.

This investigation explores two interconnected political moments that occurred over seven months of engaged anthropological fieldwork in Bolivia. The first is the MAS government's release of the agricultural plan: the Ley de la Revolucion Productiva Communitaria Agropecuaria (LRPCA) and the second is the infamous and possibly most important political conflict to emerge in Bolivia since the gasolinazo: the TIPNIS conflict. Both moments can be viewed as reflecting the larger political and economic

\footnotetext{
11 Tony Weis, The Global Food Economy: The Battle for the future of farming (London: Zed Books, 2007),
} 89-120. 
tendencies that are present in Bolivia revolving around land and agriculture. Further, both demonstrate the unparalleled and unrelenting way in which Bolivians continuously construct, negotiate, and challenge the Bolivian political process.

Chapter one explores the historical development of agricultural production in Bolivia focusing particularly on the relationship between community production and industrial agricultural production. In this chapter I argue that notions of communal property ownership and production must be situated within the colonial conquest, and later within and alongside the development of capital. As such, any real attempts by the MAS to propagate communal agricultural production and land tenure must be seen as a project that requires re-construction and necessarily requires the dismantling and destruction of colonial and capitalist forms of land tenancy, which continue to persist and thrive in Bolivia.

Chapter two introduces the Ley de la Revolucion Productiva Comunitaria Agropecuaria (LRPCA), the MAS' most recent legislative document for agricultural production in Bolivia and the source for the mobilizations against genetically modified seeds that emerged in June. In this chapter I trace the production of the law, identify the political and economic contradictions and tensions that emerged during its production and ensuing implementation.

Chapter three outlines the present political-economic context of agricultural production in Bolivia, attempting to identify and outline the possibilities for revolutionary 
communitarian production within capitalist, particularly large-scale industrialized agricultural production. In this chapter I argue that the present political and economic tendencies of the Morales administration are those that are reducing the possibilities for revolutionizing agricultural production and focus on genetically-modified seeds as one of the examples of the ways in which the LRPCA represents a danger to sovereignty and sustainability.

Chapter four looks at some of the political tensions and contradictions that emerged in light of the LRPCA and their relationship to land, property and production. Specifically, in this chapter I examine the relationship between social movements and the state, and how the MAS' government's re-imagining of politics in the context of their inability to revolutionize land tenancy has resulted in an increased political upheaval and the construction of new alliances demanding a more revolutionary political front. The Pacto de Unidad, ${ }^{12}$ a collection of indigenous and campesino communities that works directly with the government will be the primary site of analysis for this chapter. The Pacto de Unidad is particularly important for understanding these two movements given its composition (campesino and indigenous organizations), its relationship with the MAS, and the role it has held in political mobilizations of past and present.

Finally, chapter five looks at the ways in which these new alliances, particularly between working and indigenous communities emerged and were challenged and negotiated

\footnotetext{
12 The Pacto de Unidad during the time of this investigation was comprised of two indigenous organizations CONAMAQ and CIDOB, and three campesino organizations CSUTCB, Federacion Bartolina Sisa, and the Interculturales.
} 
during the TIPNIS conflict. This final chapter offers a critical analysis of the strengths and limitations of the possibilities for revolutionary change from below within the Bolivian popular and indigenous classes. 


\section{Chapter 1: Community Production and the Development of Capitalist}

Agricultural Production.

With the emergence of the LRPCA and the government's emphasis on the importance of small-scale, community-based agriculture for the future of Bolivian agriculture, discussions of the possibilities for communal small-scale indigenous production need to be examined. The central argument of this section is that any analysis of the possibilities for the MAS' vision for communal production cannot be discussed without a look at the ways in which previous forms of communal production were destroyed by colonial and capitalist conquest.

The first section of this chapter will explore the ways in which the "community" or socially organized land holdings as they existed outside of capitalism were destroyed. The second section will explore the Agrarian Reform and the state-supported roll-out of capitalist development of campesino and agro-industrial agriculture following the popular revolution of 1952. The final section will introduce some questions and commentary in order to foreground the following chapter's exploration of the MAS' most recent agricultural legislation.

While there is a recent dearth of economic studies that focus on the material production realities of agricultural communities in Bolivia (since approximately the 90 s), some past studies like Maria Lagos' study on agricultural production in the Cochabamba Valley region, Allison Spedding's comparative analysis of coca production in the Chapare and 
Yungas regions, and a compilation of studies that compare agricultural production regionally perfomed by CIPCA, suggest that community indigenous production is complex and integrally intertwined with capital. ${ }^{13}$ Despite a recent academic trend to identify indigenous communities that produce communally and then expand that case to generalizable insights about indigeneity and values as necessarily communal, ${ }^{14}$ this first chapter attempts to historically situate those claims. It also is a call out for a revival of studies which are both anthropological and economic, studies that attempt to reveal the ways in which production is tied to internal value systems and meaning, but that also is intertwined with the contextual economics of production.

Much like during colonial conquest, the rise of capital worked towards dismantling indigenous communities as a way of ensuring a labour force. And today we continue to see the ways in which industrial agricultural production has been able to expand significantly, at the expense of land available to indigenous and campesino communities. For Spedding, the anthropological tendency has been to treat agricultural communities as bounded entities void of their historical and present context. ${ }^{15}$ She does not argue that collective or communal production do not exist, but rather that the essentialism that these values are indigenous or that these values do not coincide with other ways of producing,

\footnotetext{
${ }^{13}$ See Maria Lagos, Autonomy ad Power: The Dynamics of Class and Power in Rural Bolivia (Philadelphia: University of Pennsylvania Press, 1990); Alison Spedding. Kawasachun Coca: Economia Campesina Cocalera en los Y'ungas y el Chapare (La Paz: PIEB, 2005) and Lorenzo Soliz and Silvia Aguilar, Produccion y Economia Campesino-Indigena: Experiencias en seis ecoregiones de Bolivia 2001-2003 (La Paz: CIPCA cuadernos de investigacion, 2005)

${ }^{14}$ See Susan Healey, "Ethno-Ecological Identity and the Restructuring of Political Power in Bolivia," Latin American Perspectives 36(2009): 83-100; Michael Schulte, Llameros y Caseros: La economia regional kallawaya (La Paz: PIEB Investigacion, 1999); and Isabella Margerita, El Poder de la Tierra (La Paz: Plural, 2008)

${ }^{15}$ Spedding, Kawasachun Coca
} 
needs to be complicated. Much as the development of capitalism has taken on its unique form in its appearance and development in Bolivia, so too have the concepts of indigenous values developed within and alongside capitalism. Communal property ownership and non-capitalist forms of production existed in Bolivia prior to the arrival of the Spanish, but with more than 500 years of interaction with colonial, tributary and capitalist intervention the "community" is anything but a bounded untouched entity completely preserved.

\subsection{Spanish colonialism, liberation and the colonial destruction of community}

Prior to the arrival of the Spanish, networks of agricultural production and trade were integral for the survival and expansion of the Incan Empire. Strong agricultural production and extended networks of distribution permitted not only the alimentation of Incan troops, but also permitted high levels of subsistence within and between communities through the non-mercantilist inter-communal exchange of a diversity of products. The majority of these exchanges were managed through the existing ayllu, ${ }^{16}$ networks which were based on reciprocity and exchange outside of market values, with agricultural production and land tenancy organized communally. ${ }^{17}$ These networks were

\footnotetext{
${ }^{16}$ This was the base of Andean agricultural production (which means we cannot then generalize it to represent all agricultural production in Bolivia. However, Morales' recent agricultural reforms concentrate in the highland region (predominant ayllus), and Crucena region, which is organized, as we will see in Chapter 1, primarily through agro-industrial production. Each ayllu had a chief (kuraka) who distributed and determined the use of the land for families, organized collective labour forces, and managed conflicts. Land was divided into family lots. It was also a system based in help through the exchange of work between families during the harvest, and in obligation for the redistribution of goods of the kuraka in times of famine, for example.

${ }^{17}$ Ciro F.S Cardoso and Hector Perez Brignoli, Historia Economica de America Latina: Sistemas agrarios e historia colonial (Barcelona: Editorial Critica, 1979).
} 
important for maintaining food security in times of alimentary crisis. But beyond securing food, they were also successful for obtaining a variety of goods that, given Bolivia's ecological and geographical diversity, were being produced in the Altiplano and valley regions. ${ }^{18}$ It is important to note, however, that despite their communal land organization, the ayllu system contained within it, internal elite hierarchies who oversaw the management and distribution of land and resources. ${ }^{19}$

With the arrival of the Spanish and the increased necessity for expanded agricultural production to supplement labour in the mines, the mit'a was developed which implemented mandatory labour in the mines or in public infrastructure for a set time every year. ${ }^{20}$ The mit'a was successful by appropriating the pre-existing communal organization of labour as a tool to secure the indigenous workforce to extract resources for the Spanish empire. The increased production in the mines required increased agricultural production to maintain the workforce and from the pre-existing exchange networks and passages that existed prior to Spanish conquest, the Spanish managed to facilitate this expansion quite timely. What resulted was a tributary organization of land with indigenous communities being forced to work the land to produce sustenance for the mines a set amount of time per week, and work in the mines extracting raw material for

\footnotetext{
${ }^{18}$ It is important to clarify that lowland agricultural production was excluded, as the orient region remained relatively isolated until much later on in Bolivian history. See Klein, Historia de Bolivia.

${ }^{19}$ Ximena Soruco, "De la Goma a la soya: El Proyecto Historica de la elite crucena." In, Los Barones del Oriente: El Poder en Santa Cruz y Hoy, eds: Ximena Soruco, Wifredo Plata \& Gustavo Medeiros (Santa Cruz: Fundacion Tierra, 2008).

${ }^{20}$ Klein. Historia de Bolivia
} 
direct exportation to the empire. ${ }^{21}$ The conditions of this very particular form of slavery cannot be understated, with Almaraz, in adding to Urquidi's claim "indio mitayo es indio muerto", saying "al que iba a partir a las minas se le hacia un funeral anticipado. ${ }^{22}$ Thus, a double extraction of primary resources, raw materials and labour, was required to fuel the development of the Spanish empire. What this also meant was that food production was tied to the boom-bust cycles of the mining industries, making agricultural production precarious, and contributing to a slowing down and complicating of the development from tributary to capitalist organization of land.

With the liberation of Bolivia from the Spanish in 1824, Bolivar formally abolished the mit' $a$ and embarked on a distribution of individual land plots. ${ }^{23}$ This movement did not, however, lead to the liberation of indigenous communities or reorganize the inequalities that had prevented indigenous communities from holding economic and political power. In Bolivia, a consolidation and mestization ${ }^{24}$ of power occurred, resulting in a strengthening of the latifundio and the further dismantling of "the community." And though, the "faces" of the latifundistas changed, their power and the perseverance of the system did not.

Following this revolution, what emerged was not really a class of capitalists but a class of property owners who were able to maintain the pre-existing tributary system by providing

\footnotetext{
${ }^{21}$ The structure of the mit'a in Potosi was structured as follows "... los indios debian trabajar una semana y descansar dos, de modo que el indio trabajaba por ano cuatro meses alternados...(Urquidi as cited in Sergio Almaraz, Obras Completas (La Paz: Plural, 1968), 600.

${ }^{22}$ Urquidi as cited in Sergio Almaraz, Obras Completas (La Paz: Plural, 1968), 600.

${ }^{23}$ The Bolivarian Decrees.

${ }^{24}$ The abolition of the mit'a in Bolivia resulted in the creation of an elite mestizo aristocracy.
} 
a small private plot of land to the indigenous families living on the latifundio. This property, too small for subsistence, required those indigenous communities living on the property to continue working for the owner without monetary compensation, thus maintaining the tributary system.

Upon the suspension of the "decretos bolivarianos" of 1824-25 in Sucre, in order to continue receiving rents with the decline of the mining industry latifundio continued to exist in order to benefit the national oligarchy. ${ }^{25}$ With the increasing devaluation of rents and the slow recuperation of the mining industry towards the end of the century, communal land tenancy fell under attack for the second time.

This led to the "Decreto de Confiscación" in 1866. General Malgarejo ${ }^{26}$ envisioned the abolition of communal ownership of land as part of his political catering to the national mining oligarchy. This plan outlined that indigenous communities would be given the opportunity to purchase titles to their land, and if they did not, the land would become property of the state and then sold off. This came as a result of the oligarchy's growing concerns with the fact that indigenous communities occupied three-quarters of potentially cultivable land. ${ }^{27}$ According to Almaraz, the decreto de confiscación and the resulting massacres of entire indigenous communities ${ }^{28}$ ended up unleashing violent indigenous

\footnotetext{
${ }^{25}$ Klein, Historia de Bolivia, 156.

${ }^{26}$ Elected as president in 1864 , military general Malgarejo is most famous for the initial political attempts to dismantle and destroy the communal property holdings of indigenous communities.

27 Almaraz, Obras Completas, 334.

${ }^{28}$ According to Almaraz, the events leading up to the fall of the Malgarejo government and simultaneous indigenous uprising must be understood within the context of the degree of unrelenting violence waged on indigenous communities when attempting to remove them from their territories: "La historia oficial, con explicable pudibundez, deja caer un discreto velo sobre hechos tan terribles, como la masacre de 600
} 
uprisings and fragmenting the landholder/latifundio class. ${ }^{29}$ In 1874, the "Ley de la ExVinculación" was approved by the Frias government resulting not only in the displacement but also violent massacres of thousands of indigenous communities. ${ }^{30}$ This emphasis towards individual property ownership occurred in the context of Liberal land reforms rolling out across Europe and the United States. In the case of Bolivia, this did not mean that what developed from this time on was a farmer form of capitalist production. What the "Ley de la Ex-Vinculación" actually ended up producing was a much more visual tributary land holding system further consolidating land into the hands of fewer at the expense of more of the indigenous subaltern. This in turn fueled the indigenous uprisings which ebb and flow until the armed expropriations of the revolution. And so, even with more liberalist land reforms and the institutionalization of private property ownership,

...no se presentaba de modo dominante una vía de desarrollo capitalista que pudiera identificarse con la transformación lenta de la economía empresarial capitalista, es decir, el camino de desarrollo que Lenin califica de prusiano o vía junker (algunas formas en Santa Cruz) el limitado desarrollo del mercado propio de una economía de 'enclave' minero y de débil desarrollo industrial, marco un limite a la transformación agraria de modo que no se constituyeron verdaderas empresas capitalistas agrarias sino hasta la revolución nacional. ${ }^{31}$

In Santa Cruz, prior to the Agrarian Reform, agricultural production developed distinctly from the Altiplano and valley regions of Bolivia. Prior to the twentieth century, Santa Cruz and the lowlands generally remained quite isolated from the spheres of political and

campesinos el 28 de Junio en 1869 en San Pedro, otra matanza, la de Guaicho, del 2 al 5 de enero de 1870 , donde se hizo cortar la lengua de un hombre y se torturo y asesino a la madre y parientes del heroico Villca el lider de las insurrecciones Aymara..." Ibid.

${ }_{29}^{29}$ Almaraz, Obras Completas, 336.

${ }^{30}$ Klein, Historia de Bolivia.

31 Danilo Paz, Estructura Agraria Boliviana (Plural: La Paz, 2009), 37. 
economic power. The traditional mining oligarchy controlled the economic and political terrains, with the Altiplano and valley regions (primarily departments of La Paz and Cochabamba) producing agriculture to maintain the labour in the mines. ${ }^{32}$ With the increase of industrialized sugar production for alcohol refining to export to the mines, and the Rubber Rush in the late $19^{\text {th }}$ and early $20^{\text {th }}$ century, an influx of migration to the departments of Beni and Pando heightened the need for emigration in order to extract rubber, and later, work in the agricultural fields. This resulted in an increased demand for food to maintain the workforce. With the increased presence of foreign investors but also labour, agricultural production previously marginalized from the rest of the country, began to develop. ${ }^{33}$

Given that Santa Cruz was isolated from the mining-agricultural latifundio system of agricultural production they were forced to develop other incentives to draw in migrants in order to develop the agricultural sector. One of the ways in which this was achieved was through substituting the $m$ 'ita (work-as-obligatory) system for wage labour, which liberated labour from slavery- and replaced it with a new kind of servitude, alienated labour. ${ }^{34}$ Due to the lack of labour however, production in the orient remained unable to meet demand up until the Agrarian Reform (which we will explore in the next section). Nonetheless, there was a large increase in emigration into the lowland region by Andean communities to colonize lands and begin producing for the local markets requiring food production. As Santa Cruz began to expand so did the opportunities for foreign

\footnotetext{
32 Soruco, De la Goma a la Soya.

${ }^{33}$ Roxana Ybarnegaray de Paz, El Espiritu del Capitalismo y la Agricultura Crucena (La Paz: Editorial Atenea, 1992), 28-9.

${ }^{34}$ Ibid, 65 .
} 
investment. The US was one of the first countries to capitalize on the new investment opportunities.

In 1942, the US government commissioned the "Bohan Report" ${ }^{135}$ which outlined the US' mission for development in Bolivia, ${ }^{36}$ complete with an offering of $88,000,000$ USD in foreign investment. The slightly below three hundred page policy document, among other things, outlined a very clear projection of the future of agricultural production in Bolivia, and "suggested" that Bolivia include the US Department of Agriculture in all of its agricultural proceedings. This study identified the Bolivian lowlands, Santa Cruz in particular, as 'behind' but showing great potential for agricultural development, provided that the Bolivian government (in conjunction with US aid strategies) follow their "suggestions". The report identified that "only $0.014 \%$ of the lowland region was being used for agricultural cultivation", and that there was a desperate and immediate need to produce in order to augment their production and thus export potential. The report outlined a few essential steps that the government had to take right away in order to benefit from the agricultural potential of Santa Cruz. The first of these projects was the construction of infrastructure that would facilitate transportation and integration between the Altiplano, valleys and lowlands. Out of six proposed highway projects, three were directly connected to Santa Cruz. ${ }^{37}$ The second was to provide incentives to increase the production of sugar, rice, wheat and other cereals among other crops in the lowlands.

\footnotetext{
${ }^{35}$ Merwin Bohan, "Informe de La Mission Economica de los Estados Unidos A Bolivia (Plan Bohan)," Commissioned by US Department of the State, 1942.

${ }^{36}$ This report examined two areas of economic and political intervention, oil and agriculture. The original report was written in English and then translated into Spanish a year later in order to be presented to the Bolivian government.

${ }^{37}$ Cochabamba- Santa Cruz, Santa Cruz- Camiri, Santa Cruz- Montero- Cuatro Rojos.
} 
According to the report, the ways in which Bolivia could succeed economically were through the development of national crediting schemes, the facilitation of employment of foreign investment, and adopting a comparative advantage model for agricultural development. ${ }^{38}$ According to a series of investigations assembled by CEDLA:

los postulados del plan Bohan han sido la guia básica para las políticas de desarrollo rural...esas políticas eran claramente opuestos a un desarrollo rural que privilegiara al campesinado. Al contrario, únicamente se le asignaba un importante rol como consumidor y proveedor de fuerza de trabajo a bajo costo, ante el supuesto de que el campesinado -y toda la influencia histórica-cultural y nacional indígena- no tenia capacidad creadora y productiva ${ }^{39}$

In the years following the MNR revolution, the major postulations and propositions for agriculture were implemented. This report is extremely important for understanding the emergence of the MNR Agrarian Reform that occurred in 1953, the development of agroindustry in Santa Cruz, the strategic positioning of the United States empire, and the expansion and the regional shifting of the oligarchic economic and political power.

\subsection{The Agrarian Reform and the 'Rolling-Out' of capitalism}

With the revolution of 1952, armed campesino militias from the Altiplano and valley regions of the country began instigating the agrarian revolution, expropriating landholders and occupying their estates with the objective of constructing- "la gran propiedad social. ${ }^{940}$ In order to legitimate the armed uprisings, and to consolidate the support from the campesino bases, the MNR government under Victor Paz Estenssoro

\footnotetext{
38 Ibid, 15.

${ }^{39}$ Miguel Urioste, Segunda Reforma Agraria: Campesinos, Tierra y Educacion Popular (La Paz: Talleres CEDLA, 1987), 74.

${ }^{40}$ Amado Canelas, Mito y Realidad de la Reforma Agraria (La Paz: Los Amigos del Libro, 1966).
} 
developed and produced the Agrarian Reform in $19533^{4142}$ The Agrarian Reform ${ }^{43}$ became the third major political move of the MNR revolution of ' 52 , which also included the nationalization of the mining industry and the universal vote. These uprisings, according to political theorist Luis Tapia, became an important historical-political movement, which would foreground the re-emergence of national-popular imaginary and ensuing resurgent politics during the political uprisings of the 1990's and 2000's.

Following the revolution of ' 52 , there was an insurgence of campesino politics that were heavily influenced by organized syndicalism, and supported both from below (organizing campesino organizations) and from "above" (MNR). Varios dirigentes foften appointed directly by the MNR) went into the rural areas to organize campesinos following the revolution, and consolidated the hegemony of MNR with a corporate relationship between the dirigencia of campesinos and the MNR. The campesino militias became used

\footnotetext{
${ }^{41}$ Interestingly enough, the MNR was able to discuss and implement the Agrarian Reform in Bolivia without any foreign intervention from the United States. In the early $50 \mathrm{~s}$ and with the increasingly emerging cold war insecurities and the US attempts to maintain geopolitical pressure in light of the "red scare", Latin America became a key political pawn. In Guatemala, the US backed a coup in 1954 reacted to the redistributive Agrarian Reform policies that were emerging from the government. In Bolivia's case, if we look at both the emergence of the Agrarian Reform in the context of the drawing, and eventual implementation of the Bohan Report it seems more likely that they US did not in fact have to intervene at that moment militarily because they had already intervened politically and economically.

${ }^{42}$ Two agrarian reforms were actually produced and voted on. Even though it is often claimed that this document was unanimously approved, the assembly actually tied on the vote, with Victor Paz making the final decision. Alejandro Almaraz took part in the development of the other version of the Agrarian Reform and based in the socialist tendencies in his works, I assume that the reason that this version was not selected by $\mathrm{Paz}$, possibly because the MNR had a less-than-socialist projection for agricultural production in Bolivia.

${ }^{43}$ Two agrarian reforms were actually produced and voted on. Even though it is often claimed that this document was unanimously approved, the assembly actually tied on the vote, with Victor Paz making the final decision. Alejandro Almaraz took part in the development of the other version of the Agrarian Reform and based in the socialist tendencies in his works, I assume that the reason that this version was not selected by Paz, possibly because the MNR had a less-than-socialist projection for agricultural production in Bolivia.
} 
as a "fuerza de choque contra un movimiento obrero crecientemente radicalizado" $\$ 4$ and the augmenting corruption and officialism lead to the repressive "pacto militarycampesino" during the Barrientos government.

The Pacto military-campesino was eventually dismantled and overthrown by organized popular-based indigenous and campesino organizations as a reaction to the augmenting violence and destruction from the government's policies and alliances. ${ }^{45}$ The Confederación Sindical Única de Trabajadores de Bolivia (CSUTCB) was created in 1979 in the Congreso de Unidad Campesina, organized by the Central Obrero Boliviano (COB), its formation marked the important recognition and rejection of clientalism, and solidified the beginnings of indigenous-campesino and worker alliances, with the CSUTCB obligating the recognition of indigenous participation and demands by the $\mathrm{COB}^{46}$ This is important to bear in mind for the later sections of the thesis when we return to questions of clientalism and the role of the CSUTCB in supporting the MAS government.

The Agrarian Reform set out six principal areas of action to pursue in order to liberate the majority of Bolivians previously oppressed by the feudal organization of land that had prohibited their ability to develop as a nation for hundreds of years. The Agrarian Reform had three central objectives: 1 . That the land must have a social function, 2 . The land

\footnotetext{
${ }^{44}$ Silvia Rivera Cusicanqui, "Luchas Campesinas contemporaneas en Bolivia: El Movimiento "Katarista": 1970-1980, In: Bolivia Hoy, ed: Rene Zavaleta Mercado (Mexico: Siglo Veintiuno, 1983), 131.

${ }^{45}$ Esteban Ticona Alejo, "Organización, liderazgo y representación Aymara en la Confederación Sindical Unica de Trabajadores Campesinos de Bolivia - (CSUTCB)," Convocatoria FLASCO 93-95 (Quito: FLASCO, 1995).

${ }^{46}$ Rivera, "Luchas Campesinas Contemporaneas."
} 
should belong to those who work it, and 3 . The recognition and encouragement of private property ownership. ${ }^{47}$ Although collective property ownership was not made illegal, indigenous communities were encouraged to "de-indigenize" and forfeit communal property for individual land titles, which enabled them the benefits of property ownership.

The Agrarian Reform was essential to eradicating the previously tributary organization of land in the Altiplano and thus central to relieving the extremely colonial oppression of the majority of its population. However, the reforms' refusal to liberate capital while liberating land holdings contributed to the (uneven) rolling out of capitalism, as well as opening up the possibilities for agricultural industrialization, in that it recognized and failed to expropriate the agro-industrialists in the orient. ${ }^{48}$

For Sergio Almaraz, "la Reforma Agraria ha sido la única repuesta posible al pasado de opresión, pero es insuficiente. El reparto de tierras no impedirá la acentuación de la miseria en el campo." ${ }^{49}$ It becomes clear from a look at the economic plan produced by the MNR in 1955, two years after the revolution that the socialization of capital was not on the agenda. In fact, the influence of the US's role in agriculture development as previously discussed in the Bohan Plan is central to the ways in which agriculture would be set to develop. The MNR defined the simultaneous necessity for the development of

\footnotetext{
${ }^{47}$ Arturo Urquidi, El Feudalismo en America y la Reforma Agraria Boliviana (La Paz: Libreria y Editorial "Juventud", 1990), 175.

${ }^{48}$ Fausto Beltran \& Jose Fernandez, Por Donde va la Reforma Agraria Boliviana? (La Paz: Talleres Graficos Bolivianos, 1960), 23.

${ }^{49}$ Almaraz, Obras Completas, 602.
} 
small-scale private farmer capitalist agriculture and agro-industry. Paz clarified this in 1964 in his address to the nation about the Revolución boliviana, "quiero dejar establecido que no queremos la colectivización forzosa de los agricultores." 50 This continues to resonate with the Morales' administration's projection for industrial agricultural production, something the following chapters will explore more in depth.

According to the "Plan Inmediata de Politica Economica del Gobierno de la Revolucion Nacional (PEMNR)" which was presented by the MNR in January of 1955, the path to agricultural development centered on the following two themes. First, by enlarging Bolivia's agricultural productive capacity, and second, by increasing the country's integrative capacity (with the help of foreign investment) by connecting the lowland region with the valley and highland regions. The report cites the major exiting barriers to agricultural and thus development as a whole in Bolivia, first arguing that $72 \%$ of the population lived in $33 \%$ of the total territory, leaving the lowland region, primarily Santa Cruz, essentially unpopulated, and the highland and valley regions overpopulated and unable to produce "mas que su subsistencia." This fact was meant to stimulate the massive re-location of valley and Altiplano campesino communities to populate and produce in the lowlands. It is also important to note that aside from the relocation of who would become colonizadores, the MNR also called for foreign immigration, where

\footnotetext{
50 Walter Guevara, Plan Inmediata de Politica Economica del Gobierno de la Revolucion Nacional (La Paz : Departamento de Prensa Internacional y Publicaciones, 1955), 45.

${ }^{51}$ Guevara, Plan Immediata de Politica Economica del Gobierno de la Revolucion Nacional, 99-100.
} 
foreigners would be given land plots upon their arrival- further solidifying the international interest and presence in the Bolivian economy. ${ }^{52}$

The report provides a breakdown of the four main regions that will require attention, citing Santa Cruz as the first and most important of those four. ${ }^{53}$ Santa Cruz, due to its "backward" nature would require immediate investment and attention in both areas. Roads had to be built, ${ }^{54}$ agricultural research centers constructed, and farmers provided with the necessary start-up capital in order to produce. The purpose of this section is not to reveal a complete analysis of the economic plan of the MNR, rather to identify the emphases and tendencies that contributed to a full rolling-out of capitalist agricultural production. Such a process which Victor Paz Estenssoro would cite later as being key to ensuring that: "todos los habitantes del país tengan la posibilidad de desenvolver plenamente su individualidad, en el orden material...(y) que pueden lograr el desenvolvimiento pleno de su individualidad física y espiritual." ${ }^{\text {s5 }}$

The MNR strengthened, with the emigration policies from the Altiplano and valley regions to the lowland regions, the production and reproduction of the capitalist logic of individual prosperity and growth. Given the nature of the rapid expansion of the crucena economy from the rubber and sugar booms prior to the revolution of 1952 , such logic was already present for communities who had benefited from this rapid economic growth, and

\footnotetext{
52 Ibid.

53 1. Santa Cruz, 2.Villamontes, 3. Beni, 4. Altiplano-Valles.

${ }^{54}$ The essential Cochabamba-Santa Cruz as instructed by the Plan Bohan was in the process of being constructed at the time of the release of this document.

s5 Victor E Paz, La Revolucion Boliviana: discurso del Jefe Nacional del M.N.R a los delegados de la IX Convencion del Partido el 17 de Enero, 1964 (La Paz: Direccion Nacional de Informaciones, 1964), $12-13$.
} 
set up their communities. ${ }^{56}$ This then provided fertile ground for the relatively smooth (yet uneven ${ }^{57}$ ) movement to farmer production in the region by the colonizadores. For Urioste,

Hoy quienes encabezan la lucha agraria estan constituidos por las nuevas generaciones nacidas despues de 1952. Ellos han asimilado y asumen el hecho de que, a diferencia de sus padres, no nacieron como siervos de la gleba, sino como hombres libres. "Liberados" incluso de los medios de produccion necessarios y suficientes para generar excedentes que les permitan insertarse como productores de mercancias en el Mercado capitalista y posibilitar entonces un proceso de acumulacion de capital. Y aqui, en sintesis, esta el nudo del problema que abarca hoy la realidad agraria y campesina del pais. ${ }^{58}$

As "socialist" production-for-internal markets, equal distribution of land, and national development the Agrarian Reform was unsuccessful, failing to meet what the popular classes had envisioned for the emergence of the revolution. The MNR government failed to provide skills, which would have possibly enabled small-scale agriculture to develop in ways that would support the national economy, reducing hunger and poverty in 'el campo.' Foreign investment, from the US in particular re-enforced Bolivia's dependency, and further debilitated the state's ability to internally regulate due to credit conditions. For Beltran and Fernandez (Bolivian researchers during the implementation of the Reforma Agraria), the MNR became subordinate to institutions like the IMF who, in exchange for their credit, required the implementation of free markets, the necessity to attract foreign capital, and the lowering of salaries to name a few. The MNR still maintained a state-centered capitalist development towards agricultural production in that

\footnotetext{
${ }^{56}$ Ybarnegaray, El Espiritu del Capitalismo.

${ }^{57}$ Lagos, Autonomy ad Power: The Dynamics of Class and Poner in Rural Bolivia.

${ }^{58}$ Urioste, Segunda Reforma Agraria, 14.
} 
the growing and emerging Cruceña elite was able to grow so rapidly due to significant state inversion and the failure to truly expropriate their landholdings. ${ }^{59}$

In cases where there was state investment, a majority of the state crediting went to agricultural production in Santa Cruz. ${ }^{60}$ In $1958,41.7 \%$ of crediting for agriculture from the national bank was destined for Santa Cruz. ${ }^{61}$ It was estimated in terms of foreign investment from international development agencies that between the years 1966-1978, \$148 million dollars was made available to the Bolivian Agricultural Bank (BAB) and commercial banks for agricultural credit. ${ }^{62}$ Of the credit that was directed to agricultural production between $1973-1978,68 \%$ of all commercial bank credit went to Santa Cruz, with numbers reaching as high as $96 \%$ in $1973 .{ }^{63}$ That the majority of credit went to the crucena region does not come as a surprise given both the Bohan and PEMNR emphasized the sheer importance of developing extensive systems of large-scale agriculture with national and foreign investment.

A lack of true state inversions left many small-scale producers in the Altiplano and valleys forced to sell their land, which further consolidated land tenancy and added to the reserve army of labour. ${ }^{64}$ Although this shift to capitalist production created jobs, the

\footnotetext{
${ }^{59}$ See Sorruco, De la Goma a la Soya; Lesley Gill, Peasants, Entrepreneurs and social Change: Frontier Development in Lowland Bolivia: Westiew Special Studies on Latin America and the Caribbean (London: Westview Press, 1987).

${ }^{60}$ The capital that was invested into the development of the orient came primarily from the revenues procured by the state following the nationalization of the mining industry.

${ }^{6}$ Enrique Ormachea S, Revolucion Agraria o Consolidacion de la via terrateniente? El Gobierno del MAS y las politicas de tierras (La Paz: CEDLA, 2008).

${ }^{62}$ Gill, Peasants, Entrepreneturs and Social Change, 52.

${ }^{63}$ Ibid, 53.

${ }^{64}$ Beltran \& Fernandez, Por Donde va la Reforma Agraria Boliviana?
} 
kinds of labour required to work in the crucena region in the sugar, cotton and other industries was precarious and temporary. In 1980 it was estimated that of the 28,000 agricultural workers in crucena agricultural production: 26,500 were working for contracts and as temporary labourers. ${ }^{65}$ Not only did the community-based agricultural production suffer from lack of true state investment but also it emerged (and flourished for some) in the context of agro-industrial production. When successful, it developed into farmer units of production which on the one hand created emerging agricultural elite of colonizadores while exacerbating the poverty of smaller producers on the other, thus successfully adding to the widening reserve army of labour to supply the agro-industry.

\subsection{Land and the years following the Agrarian Reform}

The Agrarian Reform redistributed land to those who had been forcibly removed and forced to live without it, along with promoting individualized production. The reform also contributed to a re-concentration of wealth in the years following the agrarian reform, peaking with the military governments, and then re-consolidating foreign capital in the neoliberal years.

The Agrarian Reform unfolded in two very distinct ways across Bolivia with the underlying tendency being the ultimate rolling out of capitalist agricultural development. Bolivia experienced an expansion of the elite class from the massive influx of industrialized agricultural production. ${ }^{66}$ Foreign direct investment became increasingly dominant concentrating directly in mineral extraction projects primarily in $\mathrm{La} \mathrm{Paz}$, and in

\footnotetext{
${ }^{65}$ Urioste, Segunda Reforma Agraria, 74.

${ }^{66}$ Ormachea, Revolucion Agraria o Consolidacion de la via terrateniente?
} 
industrial agricultural production in Santa Cruz. Between the years 1972-1979, 45 million US dollars was directly invested in the form of US direct foreign investment into the Bolivian Economy, with $49 \%$ of that investment directed into mineral extraction and $19 \%$ into agricultural production. ${ }^{67}$ Not only did this contribute to a weakening of national sovereignty in general and the continued dependency of the Bolivian economy on foreign actors, but it also contributed to an unequal and increasingly polarized distribution of wealth and thus power between La Paz and Santa Cruz and the rest of the country. ${ }^{68}$

Illegal land gifting was a key factor in the expansion of financial land speculation, leading to a concentration of power and wealth centered on land holdings. ${ }^{69}$ From the years of 1971-1978 (the Banzer dictatorship) 17.8 million hectares of land were distributed, over $90 \%$ of which were in the department of Santa Cruz. ${ }^{70}$ This led to facilitating regional foreign investment, and land grabbing for the soy industry- initially from Brazil, and later, Argentina. ${ }^{71}$ During the 1960 's and 1970 's, Bolivia experienced increased agricultural vulnerability as a result of the import-substitution policies and the peaks and crashes of food prices. Beyond land gifting, the lowland elite continued to receive concessions and bail-outs from the state given their inability to return on their mounting public and private debt which was becoming increasingly easy to access. ${ }^{72}$

\footnotetext{
${ }^{67}$ Also the top investment overall. See Pablo Ramos, Siete Anos de economia Boliviana (La Paz: Puerta del Sol, 1980), 123-128.

$6858.2 \%$ of direct foreign investment (US) was invested in La Paz, and 24.1\% to Santa Cruz. Again, the top two departments receiving direct project funding.

${ }^{69}$ Urioste, Segunda Reforma Agraria, 12.

${ }^{70}$ Ormachea, Revolucion Agraria o Consolidacion de la via terrateniente? 37.

${ }^{71}$ Urioste, Segunda Reforma Agraria, 13.

${ }^{72}$ Ybarnegaray, De la goma a la sova, 84.
} 
With the neoliberalization of the economy after 1985 under the Paz Estenssoro government, foreign direct investment (in the form of structural adjustment shock treatment) hit the country targeting (although not exclusively) agricultural production. ${ }^{73}$ That the majority of this movement took place in the lowland media luna region is no mistake, in fact it originated from the US-backed vision for the future of Bolivia combined with the development of the middle-class and bourgeoisie elite in the lowlands, as a result of the expansion of gas and agricultural sectors.

The US in conjunction with the neoliberal governments between the years 1985-2005 played a significant role in influencing the rolling out of agricultural production, particularly industrialized agriculture sector. This defined the production priorities, fixing prices and promoting unsustainable production based on the Green Revolutionary model for agricultural development. Thus, the re-articulation of the emerging Right in Bolivia cannot be seen outside of the political and economic support it was provided from within and abroad. ${ }^{74}$ As such, it was as much a political as it was economic move on the part of the US government's foreign investment strategy, one that continues to have a presence today. With the wholesale of the mining industry and the displacement of massive numbers of miners to the lowlands for work, or the urban out sprawls of major cities, inequality flourished during the "democratic years." 75 There was also, to an extent, another shift that enabled the complete rolling out of campesino capitalist agricultural

\footnotetext{
${ }^{73}$ The New Economic Plan sought to completely dismantle the mining, gas and oil industries, essentially leading to a selling-off of the country, sector-by-sector. See, Gabriela Valdivia, "Agrarian Capitalism and Struggles over Hegemony in the Bolivian Lowlands," Latin American Perspectives 37:4(2010): 67-87.

${ }^{74}$ Soruco argues that in conjunction with the growing elite in the lowland region there was a simultaneous mestizacion of those with economic and political power. Sorruco, De la Goma a la Soya.

${ }^{75}$ Lesley Gill, Teetering on the Rim: Global Restructuring, Daily Life, and the Armed Retreat of the Bolivian State (New York: Colombia University Press, 2000).
} 
production, and the creation of a new petit-bourgeois capitalist class (particularly in the colonisadora communities). ${ }^{76}$ In addition, there was an even larger proletariat working the fields of production for cash crops to supplement their inability to produce to even subsistence levels.

This "democratic" shock therapy was not accepted passively. In fact, peasant and indigenous uprisings continued to maintain a severe presence in the Bolivian political landscape, intensifying during this period. In 1990, indigenous communities from the lowland region marched in the First March for Land and Dignity to the government office in La Paz. In 1996 they marched again for Territory, Dignity and Political Participation, and pressured the eventual "dialogo nacional" in 2000. These pressures from important political and economic sectors of Bolivia forced political reforms from the neoliberal governments like the 1994 Ley de Participacion Popular ${ }^{77}$ which enabled the participation of indigenous organizations in municipal politics, and the 1996 Ley INRA which was important for adding the FES (social and economic function of land) and starting a formal process of saneamiento of land to landless peasants and indigenous communities. ${ }^{78}$

\footnotetext{
${ }^{76}$ Colonisadora communities are peasants who migrated to targeted agricultural production regions to populate the territory and produce. Following the Agrarian Reform in '53, expropriated lands were given to "colonos" in order to augment agricultural production, some were those who were involved in the mit'a system, others were those who had been subjected to tributary organization. Often colonizadores emigrated from the highland Altiplano region to the low-land and valley regions. There have been waves of coloninization historically following the revolution of '52. One of the most "discussed" colonizadores regions today is the Chapare in the Cochabamba Valley where coca is produced. See: Ormachea, Revolucion Agraria o Consolidacion de la via terrateniente,

${ }^{77}$ Postero, Now we are Citizens.

${ }^{78}$ Ruth Duran, Acaso la Tierra Esta Enferma? La experiencia de saneamiento de las tierras comunitarias de origen con CONAMAQ (La Paz: Stratos Editorial, 2010).
} 
Despite the fact that it appeared as though legislative headway was being made for land redistribution and the participation of campesino and indigenous sectors in political decision-making, the political unwillingness of the capital interests in land and production prevented this legislation from making significant headway. That being said however, it has been argued, that the Ley de Participacion Popular and the continued persistent indigenous uprisings lead to the expulsion of Gonzales Sanchez de Lozada in $2003 .^{79}$

\subsection{The re-construction of the community and the possibilities for agricultural}

\section{production}

In this section I have demonstrated the ways in which communal property ownership, when not being completely targeted and dismantled, has existed, not in isolation from capital, but within it. ${ }^{80}$ With that in mind then, it is completely essential to recognize that the possibilities for advancement towards "community-production" must be situated within the historical context from which property relations have emerged. For Mariátegui, the Spanish nearly entirely successfully destroyed communal agricultural production. For Mariátegui, the socialist agrarian question is simultaneously an indigenous one, given that elements of communist production survived over centuries, despite repeated attempts to destroy it with the widespread destruction of indigenous communities. He argues, "la supervivencia de la comunidad y de elementos de socialismo

\footnotetext{
${ }^{79}$ Postero, Now we are Citizens.

${ }^{80}$ And as persistent as the movement has been to dismantle the community, so too have the reactions against the displacement, appropriation and privatization of the commons, been resisted by Bolivians.
} 
practica en la agricultura y la vida indigena." 81 They continue to exist to some extent in some agricultural regions as a reaction to capital, as a means of subsistence or survival. ${ }^{82}$

If the agrarian question is simultaneously an indigenous one, than we can perhaps turn to the way agricultural production is organized in indigenous communities in order to postulate ways in which agricultural production can be transformed in Bolivia. Silvia Rivera argues that, "the Andean peasantry has retained it's pre-capitalist rationality and differentiated ethnic identities in spite of, and in response to modernization models. ${ }^{983}$ It is important to recognize though, the ways in which collective or communal agricultural production is intertwined and embedded within capitalist modes of production. The Morales' administration's discursive romantisization of community-based production is one that necessarily needs to recognize this fact.

If the Morales government is truly going to make an effort to strengthen community small-scale indigenous production based on exchange and communal ownership, then they have to do so while simultaneously dismantling capitalist industrial agricultural production. This continues to form the political and economic landscape within which these forms would potentially exist, and have continued to exist over time and at the

\footnotetext{
${ }^{81}$ Jose Carlos Mariátegui, Los Siete Ensayos de la Realidad Permana (Lima: Biblioteca Amarta, 1928), 35.

${ }^{82}$ Spedding argues that in Cocalero producing communities in the Yungas production could not simply be classified as either collective or individualized. In fact, depending on the economic and political composition of her case studies, the lines between "collective" and "individual" were blurred, and shifted and negotiated based on the production conditions, environment, political organization, internal agreements or arrangements etc. See Spedding, Kawasachun Coca.

${ }^{83}$ Silvia Rivera Cusicanqui. "Liberal Democracy and Ayllu Democracy in Bolivia: The case of Northern Potosi," Journal of Development Studies 26:4 (1990).
} 
expense of impoverishment, marginalization and dependency of indigenous and campesino populations.

The following section will examine the current MAS administration economic and political positioning on land and agricultural production, the recently approved, Ley de la Revolucion Productiva Communitaria Agropecuaria (LRCPA). In the next chapter I will argue that the LRPCA and the 2006 economic and political policy document El Plan Nacional de Desarrollo "Bolivia Digna, Soberana, Productiva y Democrática para Vivir Bien" in fact provide many opportunities for capitalist development to continue developing in the way that we have seen it explode since the Agrarian Reform by continuing to encourage small-scale campesino capitalist production alongside largescale industrialized agriculture. The small and medium size production, and communal production, as propagated as the new future for agricultural production by the MAS I argue is in fact an "anti-capitalist" myth. As such in this section, I will explore the possibilities of what one government official, Lic. Gonzalo Vargas Rivas warned me in an interview we had regarding the law when he said,

Creo que la ley de la revolución productiva comunitaria, tiene una fuerte carga de la opinión y los intereses de esta capa dirigencia [campesino], que en este momento, mas esta en una estrategia de cooptar la institucionalidad estatal del mundo republicano liberal, antes que de su estrategia comunitario. Por tanto, la ley, creo en mi opinión, que tiene un cierto se riesgo, ¿no? Que a la larga, si no se corrige puede ir favoreciendo las estructuras de economía de intercambio hacia el mercado, antes que las lógicas de organización económica comunitaria, que podría restablecer mas esto que el presidente, esto que la constitución dice, ¿no? una adecuada relación de la sociedad humana con el medio ambiente. O sea en otras palabras, defensa de la madre, defensa de los derechos de la madre tierra, ¿no? ${ }^{84}$

\footnotetext{
${ }^{84}$ Interviewee Requested that this statement be clearly identified as his personal opinion and not that of the Department of Cochabamba. Interview in Cochabamba, August 8, 2011.
} 
In this statement there are several allusions that are made which the following chapters will seek to tease out. Some of the key questions that the next section will explore are "what model of agricultural development is the MAS government pursuing with the LRPC.A?" as well, "how does this model for agricultural development conflict, contradict or become negotiated with indigenous and campesino communities?" These questions are central to understand not only the present within which we can see the tendencies of the past, but also for assessing the possibilities for the future of agricultural development in Bolivia. 


\section{Chapter 2: The Ley de la Revolucion Productiva and the Contradictions of Capital}

In the summer of 2009 , the member organizations of the Pacto de Unidad worked with its authorities, advisors and bases to produce La Estrategia Plurinacional de la Década Productiva Comunitaria (la Decada ${ }^{85}$ ). This national agricultural strategy sought to address national food sovereignty. The Pacto de Unidad ${ }^{86}$ developed this strategy over a process that spanned 2 years of production, working and re-working, and debate. ${ }^{87}$ All of the member organizations of the Pacto de Unidad participated in this long production process, which was headed by the CSUTCB, but included participation at all levels of the CONAMAQ, CIDOB, Bartolina Sisas and Interculturales. La Decada would later become the LRPCA, simultaneously raising questions regarding its political-economic and social underpinnings.

The following chapter looks at both the historic development of the LRPCA, as well as the present political-economic context of agricultural production and land tenancy in Bolivia. Within this chapter I will look to the ways in which capitalist agricultural development in the context of national and international pressures has affected both

\footnotetext{
${ }^{85}$ Also commonly known as the "Ley de la Decada".

${ }^{86}$ The Pacto de Unidad is a national umbrella representational body that directly collaborates with the government. Up until January 2012 the Pacto de Unidad officially included membership of 5 campesino and indigenous organizations; CONAMAQ, CSUTCB, Interculturales, Federation Bartolina Sisa, and the CIDOB (See appendix for short description). As I will discuss in chapter four however, following the LRPCA and later TIPNIS conflict the CIDOB and CONAMAQ began to distance themselves from this body, with CONAMAQ ultimately announcing its withdrawal from the Pacto de Unidad in January 2012. As I will explore in chapter 4, the Pacto de Unidad presents us with as a site of tension and contradiction illuminating both the possibilities and limitations of institutionalizing participation between civil society organizations and the government.

${ }^{87}$ Interview with ex vice minister of land and advisor to CSUTCB.
} 
small-scale production and the possibilities for its expansion within a system of industrial agricultural production.

\subsection{Ley de la Decada: Two years of hard work}

The CSUTCB has a history of developing agricultural Public Policy ${ }^{88}$ - their participation, along with that of the Pacto de Unidad has also, since 2005 , increased with the MAS' encouragement of popular participation. As a result, the Pacto de Unidad (with the CSUTCB heading the initiative) between 2009 and 2011 compiled their latest vision for agricultural production in Bolivia, La Decada.

Specifically, this strategy mapped out a plan for national food sovereignty which would emphasize ecological production with the goal of the "reactivación económica de la actividad productiva de las comunidades sujetos de la economía comunitaria para el logro de la seguridad y la soberanía alimentaria respetando los derechos de la madre tierra para el vivir bien de las y los bolivianos." 89 The plan went on to outline the importance of producing in ways that would preserve and protect mother earth and the environment, stating "promoción de prácticas ecológicas...respeto por los derechos de la madre tierra para el bien común..."90

\footnotetext{
${ }^{88}$ The CSUTCB has historically produced counter-legislation to previous capitalist and neoliberal governments. Given that they have existed as a collection of union bodies and campesinos since the eighties, they have actively been pursuing legislation around agriculture and land as a way of deconcentrating power and wealth. In 1984, for example, they produced the Ley de Agraria Fundamental which sought to question and dismantle the growing concentration of elite landholders which prevented the ability for campesino production. See Urioste, Segunda Reforma Agraria.

${ }^{89}$ Article 4.

${ }^{90}$ Article 5.2.
} 
During the process of construction, a point of debate surrounded the question of genetically modified organisms (GMOs). Ultimately it was decided throughout the proceedings of the production of the law, that ecological production would be more beneficial for indigenous and campesino agricultural producers as well as the environment. In the next section we will return to this issue regarding the LRPCA where the issue of genetically modified seeds resurfaced and catalyzed popular organizing. What I wish to emphasize here is that the Pacto debated the issue, and ultimately decided not to allow them, opting to strengthen ecological "traditional" production.

One of the other significant propositions that La Decada outlined was the central importance of the state. In the law they argue for the importance to "priorizar la inversión publica del Estado...en la producción, transformación y comercialización de la actividad agrícola..."'1 According to Victor Comacho, ex-viceministro de Tierra and advișor to the CSUTCB during the creation of La Decada:

...[La Decada] decía, primero que la priorización de recursos de la instancia nacional, gobiernos departamentales, municipales, que mínimamente deberían destinarse en los presupuestos el 30\%. Esa era clave. El 30\% dentro los presupuestos para incentivo la producción indígena originaria campesina... La CIDOB decía no hay problema, CONAMAQ decía no hay problema. Por que eso, en el fondo la teoría es fácil, repetir bonito que... Pero en la práctica, que aquí $l o$ obligamos a este estado... ${ }^{2}$

And so, the MAS government was assigned a central role in encouraging production at the community level. In making the claim for $35 \%$ investment,${ }^{93}$ the organizations and their membership were arguing that in order to truly begin producing, there would have

\footnotetext{
91 Article 6.1.

${ }^{92}$ Interview: Cochabamba, $18^{\text {th }}$ of July, 2011

${ }^{93}$ Article 8, I.
} 
to be significant state investment. In emphasizing a plan centered on national food sovereignty, La Decada clearly defined the role of the state as obligating the municipalities to actively and economically fortalize agricultural production. This ensured that the state would have a significant role in strengthening small-scale production. ${ }^{94}$

As we saw in chapter one several authors cited one of the key problems with the Agrarian Reform of 1953 was a lack of state investment into small/community agriculture which lead to a concentration of inequality and poverty. ${ }^{95}$ The report, in defining a ten year plan for the development of agricultural production identified key areas for state investment including revitalizing soils, investments in research centers and in machinery, and the promotion of "producción tradicional, convencional y orgánica."

Therefore, over a two year period, La Decada developed into the written product of debate, contestation and negotiation between member organizations of the Pacto de Unidad, their leaders and their bases. This process was not only significant for developing agricultural policy, but it was also reflexive of a much larger gain, that being the direct participation of the popular classes in formal politics. What happened after its development, however, suggests something different.

\footnotetext{
${ }^{94}$ It also important to note the autonomous role assigned to the campesino and indigenous comunities with regards to management of funds. The law outlined the necessity not only for steep state investment, but also for its withdrawl of the role of the state with regards to managing and distribution of funds, eliminating the bureaucratic process which can slow-down or prevent the transfer and use of funds. Comacho argued that this was in fact one of the ways that the MAS could begin to decolonize the relationship between indigenous-campesino communities and the state.

${ }^{95}$ Beltran \& Fernandez, Por Donde va la Reforma Agraria; and Gill, Peasants, Entrepreneurs and Social Change.

${ }^{96}$ Article 9, II.4.
} 


\subsection{The Ley de la Revolucion Productiva Communitaria Agropecuaria: Consultation, Contradiction and Consent}

Once La Decada was finalized and signed by the Pacto de Unidad it entered the newest phase (and end) of its life. After the production process with the Pacto de Unidad, the law entered a process of state revision. It should be noted that it is completely normal for laws to enter into this revision process after they have been put forth by various organizations. The significance, however, for this case as well as others, is how and in what ways the law becomes changed, and what the public consultation process yielded in terms of propelling power upwards. Those who participate in the production of the law, and those who have the power to change, modify, and/or influence its final form must be recognized as actors from different political and economic influences. As such, those who are invited to counter or enhance the political documents often created by the popular classes tend to have more political and economic power.

Several scholars have noted the limitations on the Bolivian consultative process when communities are fronted with capitalist interests. Villegas ${ }^{97}$ and Vargas both argue that despite the protections of rights within the NPCE, when fronted with capitalist interests

\footnotetext{
${ }^{97}$ Pablo Villegas, “¿Puede haber Consulta Previa entre la escopeta y las palomas?” Petropress 22 (2011): 9; and Miguel Vargas, "Participación y consentimiento libre, previo e informado," Petropress 16 (2011): $18-21$.
} 
the state has demonstrated a tendency to act in favour of capital. This tendency was also highlighted during the TIPNIS conflict. ${ }^{98}$

Such a theme was also evident in the case of the LRPCA. A tri-commission of the ministries of Rural Development \& Land, Environment \& Water, and Autonomy \& Health, Productive Development \& Plural Economy, and Rural Development ${ }^{99}$ was assembled to "modify language and develop suggestions." 100 From these meetings emerged the Ley de la Revolucion Productiva Communitaria Agropecuaria (LRPCA) and an entirely different vision and plan for the development of agriculture in Bolivia. Thus, despite the fact that La Decada had undergone a rigorous two-year process, upon entry into the tri-counsel it changed significantly. According to Heber Araujo, a Bolivian agricultural researcher, the LRPCA, contrary to its pro-environment and pro-community production elements:

...no asume medidas contra el latifundio, la extranjerización de la tierra, más por el contrario... En resumen, se consolidará a las empresas mixtas que controlan las semillas y su paquete tecnológico, se abrirá nuevos nichos de mercado para las transnacionales de seguros y de la banca comercial y se beneficiará a los grandes agropecuarios facilitándoles la introducción de maquinaria y agro tóxicos en desmedro de la Madre Tierra. ${ }^{101}$

What was released by the government in June of 2010 barely resembled La Decada. In terms of a surface analysis the law itself grew from a short 15 articles in La Decada to an extensive 47 articles, without adding much concrete political or economic content. For

\footnotetext{
${ }^{98}$ See Francescone, Marching for Land, Dignity; and Webber, Revolution against "progress".

99 SOMOS SUR, Ley de la Revolución Productiva Agropecuaria y Comunitaria: Quien GANA y quien PIERDE (Cochabamba: SOMOS SUR, 2011).

${ }^{100}$ Ibid.

${ }^{101}$ Heber Araujo, Ley de Revolución Productiva Agropecuaria para el Agronegocio y la Banca (Cochabamba: CENDA, 2011).
} 
Comacho, “... [en la LRPCA] hay palabras muy bonitas, pero el primer sentimiento que he sentido, he dicho, ¡no pucha! es mas discurso digamos, ¿no? Por que el otro era tres hojitas, pero te plantea las decisiones." The new law was in fact heavily loaded with general guidelines, and lacked clear political policies or strategies, resembling more closely the NCPE than a law. Upon closer analysis it appeared as though the LRPCA opened up too many opportunities for transnational capital on the one hand, ${ }^{102}$ and for the stimulation and expansion of OECOMS on the other. ${ }^{103}$ And this occurred without adequately addressing persisting problems of latifundios and alienated labour. What happened during the second phase of the process which contributed to such significant changes in the essence of the law?

When the tri-council was assembled to re-work the law the aforementioned ministries also met with the capitalist agro-industrial sector, representatives from ANAPO and C.AINCO ${ }^{104}$ of the cruceño lowland region. Despite the fact that the agro-industry, especially in Santa Cruz, presently represents nearly half of Bolivia's agricultural production, ${ }^{105}$ it cannot be forgotten that those interests represent a clearly elite capitalist class interest, which primarily produces cash crops, and agro-fuels. In fact, Eduardo Paz, the president of CAINCO in June of 2011, applauded the Morales' administration when referring to the new LPRCA saying, "el gobierno ha expresado su disposición a

\footnotetext{
102 Villegas, "Analisis de la LRPCA."

103 Araujo, Ley de Revolución Productiva Agropecuaria.

${ }^{104}$ The Camara de Industria, Comercio, Servicios y Turismo de Santa Cruz is an institution known for not only it's capitalist agro-industrial model of agricultural development which includes it's solicitation of transgenic seed development research projects.

${ }^{105}$ In 2009 , Cruceña production amounted to $42 \%$ of national agricultural production (majorly cash crops like Soya and Sugar). See: Centro Boliviano de Economia (CEBEC), Estudios Economicos "El aporte de Santa Cruz a Bolivia: Aspectos Socioeconomicos" (CAINCO: Santa Cruz, 2008).
} 
considerar y analizar el tema de la biotecnología para su aplicación al proceso productivo boliviano. Es un avance importante." ${ }^{106}$ Despite the Morales Administration's attempts to defend the LRPCA and genetically modified organisms (in light of popular protest), to date Bolivia continues to see increased collaboration with CAINCO and ANAPO, both organizations that collaborate with companies involved in genetic seed modification and innovation.

It was popularly argued that the government was actually making concessions to the agro-industrialists (cruceña, and transnational) with the LRPCA. This became a material reality when it was announced that the government would guarantee crediting not only small and medium agricultural businesses but that funding for agro-industrialist would benefit as well, to increase production. On September $1^{\text {st }}, 2011$, president Morales attended the Foro Económico Internacional Produciendo Alimentos para Bolivia y el Mundo organized by CAINCO. Here, he congratulated the Santa Cruz agro-industry for compiling a report that would "be beneficial for all Bolivians." Not only did he express verbal support, but also backed up the speech with the promise of national funding for large-scale productive enterprises, “...por primera vez en la historia hay créditos para los pequeños y medianos productores, pero también tenemos disponibles casi 200 millones de dólares para el gran empresario agroindustrial." ${ }^{\text {107 }}$

This is paradoxical. Within the LRPCA, state crediting appears under the heading of the Fondo Creditico Comunitario (FCC), which is created, in order to provide financing

\footnotetext{
${ }^{106}$ SOMOS SUR, La Ley de la Revolucion Productiva, 2011.

${ }^{107}$ Araujo, Ley de Revolución Productiva Agropecuaria.
} 
opportunities for state recognized OECOMs ${ }^{108}$ or small-producers. However, this does not prevent large producers from benefiting from the state subsidized "áreas estratégicas" which include infrastructure, machinery, genetic resources (which include seed research centers and banks ${ }^{109}$ ) and strategic crops which are defined as central to daily Bolivian consumption. ${ }^{110}$ Therefore, despite the fact that the LRPCA contains language that ensures that crediting and subsidies will prioritize small-scale producers, the agroindustrialists are receiving 200 million dollars. Beyond the simple presence of crediting, one also has to question the ways in which, in the event of failure to make payments on credits, those debts will be resolved? Will campesino-indigenous producers be made to forfeit their land to the government or to private crediting firms? Who will then have access to that land? As we saw in chapter one, this process lead to increased consolidation of land tenancy, plus a squeezing of the already scarce resources available to campesino and indigenous communities.

If what La Decada envisioned was to encourage small-scale community based production, why then were these actors invited to participate, when there are clear contradicting interests? ${ }^{111}$ Was it not similar initiatives emerging out of the Agrarian Reform of 1953, which increased state crediting for agro-industrialists making it more

\footnotetext{
${ }^{108}$ OECOMS have to be recognized through their registration with the state as a organizacion economico communitario, which is essentially small-scale productive businesses. See Article 51.

${ }^{109}$ In a commissioned CAINCO report on agricultural production in Santa Cruz completed in 2008, the CEBEC argues that the continued large-scale agro-industrial production "se ha visto acompañado por una serie de mejoras e innovaciones tecnológicas, como la siembra directa o el mejoramiento de semillas, que hace de Santa Cruz de la Sierra un centro de apoyo y servicios a las diferentes zonas productoras del Departamento." CEBEC, Estudios Economicos, 15.

110 Article 7.8 .

${ }^{111}$ Here I am implying that the contradicting interests are actually those between the vision for the La Decada and that of agro-industrial industrialists. I am not, however, trying to imply that these interests did not have commonalities, that is to say common capitalist interests.
} 
difficult for small producers to produce, obtain credit, and compete in markets? Did this not lead to a further unequal distribution of economic and political power, and strengthen the elite class in the lowland regions?

If the objective of the Bolivian state is in fact, to increase food sovereignty, work towards eliminating the food crisis, and strengthen small-scale agricultural production then we should see that reflected in the law itself which is the present exemplar of political movement. Further, we should also see it reflected in the forms of production that presently exist, given that the MAS has held the presidency since 2005. The LRCPA argues that the law will work towards ensuring that the Bolivian population has access to food ${ }^{112}$ emphasizing the importance of products that are consumed daily by Bolivians. ${ }^{113}$ According to the FAO's most recent databases, out of the top 20 agricultural products produced in Bolivia in 2009 soy production was the second highest product produced with 1,499,380 MT produced that year, second only to cattle meat. Comparatively, wheat production that year held the $13^{\text {th }}$ position with 239,367 MT produced (see Table 1). Furthermore, between the years 2005-2009 of the top twenty agro-exports, soy products (soybeans, soy cake, and soybean oil) make the top 5 in 4 out of the 5 years (See Table 2). The majority of soy produced in Bolivia is produced in Santa Cruz. Bolivians do not consume soy, nor can they consume many of the soy-by -products.

\footnotetext{
112 Article 12.12.

${ }^{113}$ Article 7.8 .
} 


\begin{tabular}{|l|l|l|l|l|l|l|l|l|l|l|l|}
\hline \multicolumn{10}{|c|}{ Table I: Agricultural Production In Bolivia } \\
(Millions of Metric Tons) \\
\hline & $\mathbf{1 9 9 9}$ & $\mathbf{2 0 0 0}$ & $\mathbf{2 0 0 1}$ & $\mathbf{2 0 0 2}$ & $\mathbf{2 0 0 3}$ & $\mathbf{2 0 0 4}$ & $\mathbf{2 0 0 5}$ & $\mathbf{2 0 0 6}$ & $\mathbf{2 0 0 7}$ & $\mathbf{2 0 0 8}$ & $\mathbf{2 0 0 9}$ \\
\hline Soy & .97 & 1.20 & 1.15 & 1.25 & 1.59 & 1.59 & 1.69 & 1.62 & 1.60 & 1.26 & 1.50 \\
\hline Wheat* & & & & & & & & & 0.17 & 0.20 & 0.24 \\
\hline & $*$ No data for wheat preceding 2007 because wheat was not in the top 20 products produced in Bolivia \\
\hline
\end{tabular}

Upon saying this however, in terms of economic capitalist export-oriented production, small-scale production is simply not profitable for foreign capital. And so, the question must be asked what is at stake? If $42 \%$ of Bolivia's agricultural and wood production comes from the department of Santa Cruz it is a large economic stakeholder in the ways in which agriculture continues to expand in Bolivia. Since agricultural production in Santa Cruz is now almost entirely industrialized (as we saw in Chapter One) we must then ask to what extent foreign and international stakeholders are also influencing this movement from imagined small-scale production and national food sovereignty to industrialized export-production. 


\begin{tabular}{|c|c|c|c|c|c|c|c|c|c|c|}
\hline \multicolumn{11}{|c|}{$\begin{array}{l}\text { Table II: Top } 5 \text { Agricultural Exports/Imports: Bolivia } \\
\text { (Millions US\$) }\end{array}$} \\
\hline & \multicolumn{2}{|l|}{2009} & \multicolumn{2}{|l|}{2008} & \multicolumn{2}{|l|}{2007} & \multicolumn{2}{|l|}{2006} & \multicolumn{2}{|l|}{2005} \\
\hline & Tons & Value & Tons & Value & Tons & Value & Tons & Value & Tons & Value \\
\hline \multicolumn{11}{|l|}{ EXPORTS } \\
\hline $\begin{array}{l}\text { Cake of } \\
\text { Soybeans }\end{array}$ & 0.96 & 332.3 & 0.81 & 270.4 & 1.02 & 227.7 & 1.11 & 211.4 & 1.04 & 204 \\
\hline Soybean Oil & 0.20 & 162.2 & 0.15 & 172.4 & 0.20 & 138.5 & 0.23 & 118.8 & 0.21 & 113.2 \\
\hline $\begin{array}{l}\text { Sugar } \\
\text { Refined }\end{array}$ & 0.17 & 64.7 & 0.13 & 44.8 & - & $\cdot$ & - & - & - & - \\
\hline $\begin{array}{l}\text { Sunflower } \\
\text { Cake }\end{array}$ & 0.13 & 27.4 & 0.09 & 23 & - & $\cdot$ & - & - & - & - \\
\hline Soybeans & 0.13 & 47.5 & 0.09 & 33.7 & - & - & 0.07 & 15.2 & 0.15 & 33.4 \\
\hline \multicolumn{11}{|l|}{ IMPORTS } \\
\hline $\begin{array}{l}\text { Flour of } \\
\text { Wheat }\end{array}$ & 0.30 & 104.4 & 0.23 & 115.9 & 0.22 & 67.8 & 0.16 & 33.2 & 0.13 & 26.1 \\
\hline Wheat & 0.06 & 17 & 0.09 & 27.9 & 0.10 & 20.4 & 0.13 & 21.1 & 0.21 & 32.6 \\
\hline Food Prep. & 0.01 & 50.2 & 0.02 & 50.5 & 0.01 & 39.9 & 0.01 & 30.1 & 0.01 & 27.8 \\
\hline Rice Milled & - & - & 0.04 & 22.3 & $\cdot$ & 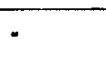 & - & $\cdot$ & - & - \\
\hline Soybeans & $\cdot$ & - & 0.06 & 24.8 & 0.24 & 59 & 0.21 & 42.8 & 0.14 & 42.8 \\
\hline
\end{tabular}

The Canadian government also has a role in the supporting industrial agricultural production in Bolivia. Specifically, it is interesting to note a recently funded project by the Canadian International Development Agency (CIDA), "Supporting Agro-Industrial 
Production and Exports"(\#A034923-001). The total funding from CIDA is $\$ 12,250,000$ and has been approved for 2010-18. According to CIDA's website ${ }^{114}$ the project is focused at "strengthening Bolivian entrepreneurial, technical and managerial capacity for the cultivation, processing and distribution", and despite the fact that this program will "involve poor rural families in the production process," $70 \%$ of the projected funding is directed directly to the Agro-Industries, with the other $30 \%$ spreading out over education, training, research and inputs. ${ }^{115}$

The existence of the Comunidad Andina de Naciones providing regional markets for soy ${ }^{116}$ and expanding foreign soy-import markets in Asia makes Bolivia a prime hotbed for capitalist agro-industrialists to set-up shop. This is especially relevant in the cruceña region where approximately $29 \%$ of the department is still forested, ${ }^{117}$ making it a prime location for financial speculation and foreign investment. As such, it has been noted that national and transnational companies, primarily but not exclusively Brazilian, are buying up land whenever they can. ${ }^{118}$

\footnotetext{
114 There is actually no project information available by the executing agency "SOCODEVI."

115 See more project information online at: http//www.acdi.cida.ge.ca/CIDAWEB/cpo.nsf/vWebCSAZEn/A94933828476C182852577F2003C9487

"16 Gustavo Medeiros, "Evolución y Características del Sector Soyero en Bolivia," in: Los Barones del Oriente: El Poder en Santa Cruz Ayer y Hoy (Santa Cruz : Fundación Tierra, 2008).

117 Ministerio de Desarollo Productivo, Atlas de Potencialidad Productiva : Santa Cruz (La Paz: Ministerio de Desarollo Productivo, 2009), 119.

${ }^{118}$ This is why the controversial bighway project San lgnacio de Moxos-Villa Tunari was such an important geopolitical and economic move for the Brazilian government and transnational IIRSA. In completing the highway they would have connected the major routes required to connect them directly to the pacific coast to ship Soya to China. See: Urioste, Concentración y extranjerizacion; and Villegas, "Analisis de la LRPCA."
} 
Beyond the presence of multinational and transnational interests, Bolivia still maintains an active relationship with large neo-colonial financial organizations of the past. Recent foreign capital investment projects by the World Bank, and the Inter American Development Bank clearly target agricultural production. The 2011 Agricultural Innovation and Services Project funded by the World Bank for example totals 39 million US dollars of credit to the Bolivian government over five years ${ }^{119}$ (project total cost is 52.90 million). This project outlines its objective of " ...the improvement of INIAF's research and INIAF's core research capacity, the improvement of INIAF's provision and coordination of technical assistance, the consolidation of the national seed system, and the management of national genetic resources." ${ }^{\prime 20}$ Bolivia has a very particular history with foreign investment, especially from its previous partnerships with the World Bank during the Structural Adjustment Reforms that resulted in the complete collapse of the mining industry. According to Ormachea the MAS' land politics really have not changed substantially from those imposed by the World Bank and IFIs in the 1990's. ${ }^{121}$

The LRPCA does not discourage or discount the possibilities for foreign investment; in fact it outlines the ways in which the Bolivian State will "celebrar convenios, acuerdos de cooperación técnica y operativa con las instancias institucionales publicas, privadas, nacionales o internacionales." 122 In the past increased foreign "collaboration" lead to economic dependency and collapse. It was also explicitly met with popularized

\footnotetext{
119 The Danish and Swiss governments are covering the remaining difference.

${ }^{120}$ In the official report summary, it is argued that goal of the project should be reinforcing the institutional INIAF "el énfasis durante el periodo del proyecto estará necesariamente en la consecución de beneficios institucionales más que en beneficios posibles en las condiciones de vida y la productividad para la población rural." Ibid, 12.

${ }^{121}$ Ormachea, Revolucion Agraria o Consolidacion de la via terrateniente, 106.

${ }^{122}$ Article 33.7.
} 
resistance, which, as we will explore later, has again emerged in response to this law, and the position of the MAS in regards to foreign capital at present.

Thus, it would appear as though the LRPCA would not in fact, serve to benefit smallscale ecological production with the end of obtaining food sovereignty for Bolivia. Or, in the event that foreign investment projects attempt to sell their investments by contributing to the "economic development" of a select few Bolivians, as I have argued earlier, the promotion of industrialized agricultural production has historically resulted in increased poverty, marginalization, and precarity.

As history has shown us, there are several ways that can exemplify the implementation of industrial-capitalist production. The following sections will explore one of the ways that the agro-industry's continued expansion will be facilitated, through the legalization of Genetically Modified Organisms (GMO). Here I demonstrate that not only is the GMO question an environmental one, but that it also reflects the dangers of economic and political dependency and contracts the claim that small-scale/campesino production will be the solution to the Bolivian food crisis. 


\subsection{Genetically Modified Organisms}

There is abundant literature that explores the negative effects of genetically modified organisms, including the ways in which they create increased inequality, exacerbate farmer's dependency, and are environmentally destructive. ${ }^{123}$ In Canada, the famous precedent-setting case regarding Percy Schmeizer was the first of still ongoing examples within the North American context where capitalist giants like Monsanto have sued farmers for millions of dollars for producing patented seeds. Genetically modifying organisms with the end of patenting-for-profit is another example of primitive accumulation whereby displacement occurs as capital unrelentingly seeks out new markets- during this process social relations of production become commodified for the purpose of the continued extraction of surplus- in this example, at the behest of socially owned and communally produced and shared seeds.

With regards to the Global South, there is also literature, which focuses on the ways in which the imposition (consensual or through the use of coercion) of genetically modified seeds has been a neo-colonial capitalist project. ${ }^{124} \mathrm{~A}$ project often imposed on countries of the 'global south', which, like we saw with cases like the Green Revolution and are seeing with Mexican maize. ${ }^{125}$ This model was envisioned to bring modern agricultural

\footnotetext{
${ }^{123}$ Raj Patel, Stuffed and Starved: Markets, Power and the Hidden Battle for the Global Food System (New York: Portobello Books, 2007); Tony Weis, The Global Food Economy: The Battle for the future of farming (London: Zed Books, 2007): 89-120.

${ }^{124}$ Annette Desmarais, La Via Campesina: Globalization and the power of peasants (Winnipeg: Fernwood Publishing, 2007), 40-74; and Weis, The Batle for the Future, 2007.

${ }^{125}$ Elizabeth Fitting, The Struggle for Maize: Campesinos, Workers, and Transgenic Corn in the Mexican Countryside (United States: Duke University Press, 2011).
} 
systems and thus development to the "third world."126 This process has had irreversible economic, political, socio-cultural and environmental impacts, and is incorrectly based on the assumption that the ways to solving hunger and poverty in the world are through increased production, a thesis which has been negated time and time again in practice. La Via Campesina, a global campesino movement seeking to link the experiences of campesinos in the Global South to those in the Global North has adamantly expressed the dangers of corporate GMO research and provision of inputs, seeds in particular, that result in a shift of the power away from farmers. ${ }^{127}$ This results in a loss of control over seed saving and a dependency on patented seeds to which they might not have access.

\subsection{Genetically modified Organisms in Bolivia: Past and Present}

Specifically in Bolivia, (in the years following the New Economic Plan of 1985 the imposition of extreme neoliberal restructuring) reform seed technology packets were introduced as part of the conditions placed on internationally funded development projects which included modified seeds, along with the required chemical inputs to ensure their growth. ${ }^{128}$ Because these seeds have been modified to grow under controlled conditions they always require chemically intensive inputs in fertilizers, pesticides, and herbicides. ${ }^{129}$ These inputs may increase production rapidly in the short-term but

\footnotetext{
${ }^{126}$ Norman Borlaug, The Green Revolution Revisited and the Road Ahead. Online Lecture PDF format. Accessed Online, October 12,2010 at htp:/inobelprize org/nobel prizes/peace/laureates/1970/borlaugarticle.html"print .

127 Desmarais, La Via Campesina.

${ }^{128}$ Heber Araujo, Etmodesarrollo, Tierra Y Vida: Una alternativa a la crisis alimentaria y energética (Cochabamba: CENDA, 2010).

${ }^{129}$ As such, several campesino producing communities both in the highland and valley regions in Bolivia still display the remnants of these impositions. Some communities still use fertilizers and pesticides, their
} 
contribute to such environmental destruction and economic dependency in the long-term that they destroy the possibilities for prolonged sustainable food production. Campesino dependency and vulnerability to fluctuations in international market prices for foodstuffs and oil, to unforeseen climate or environmental changes, and their inability to produce to reduce growing debt resulted in the sale of land. ${ }^{130}$ This in turn increased migration to the urban centers like El Alto, ${ }^{131}$ or to the diversification and expansion of work, often doubling with labour in formal and informal sectors. ${ }^{132}$ The West's ${ }^{133}$ philanthropic Green Revolutionary 'gift' which promised increased production for Bolivia in fact continued to produce more generalized and deepened inequality. ${ }^{13+4}$

The LRPCA has three articles that contain the possibility for the legalization and production of genetically modified seeds. ${ }^{135}$ For example, the LRPCA claims that it will establish "disposiciones para el control de la producción, importación y comercialización de productos genéticamente modificados," making the assumption that first, genetically

traditional or past means of production having been destroyed by the seed packets, or by their inability to compete with local food stuffs in a market that with the deregulation of internal markets, allowed for the flooding of national markets with cheap food imports from the Global North.

${ }^{130}$ Nicole Fabricant, "Ocupar, Resistir, Producir: Reterritorializing Soyscapes in Santa Cruz," in: Remapping Bolivia: Resources, Territory and Indigeneity in a Plurinational State, eds: Nicole Fabricant \& Bret Gustafson (Santa Fe: SAR Press, 2011).

${ }^{131}$ Gill, Teetering on the Rim; and Carlos Revilla, "Understanding the Mobilizations of Octubre 2003: Dynamic Pressures and Shifting Leadership Practices in El Alto," in: Remapping Bolivia: Resources, Territony and Indigeneity in a Plurinational State, eds: Nicole Fabricant \& Bret Gustafson (Santa Fe: SAR Press: 2011).

${ }^{132}$ Gill, Teetering on the Rim; and Valdiva, Agrarian Capitalism and Struggles over Hegemony.

${ }^{133}$ World Bank, USAID, NGOs. See Araujo, Etnodesarrollo, Tierra Y Vida.

${ }^{134}$ As was common with the majority of global South countries that had the Green Revolution model of agricultural development imposed on them through structural adjustment policies. See Vandana Shiva. "Un ataque contra los recursos y el patrimonio de los paises". Rebellion (2007).

${ }^{135}$ Interestingly enough, while the MAS government was drafting up a law that would permit the legalization of genetically modified organisms, the Peruvian and Chilean governments were reviewing their legislation on the matter, with the Peruvian government placing a 10 year moratorium on GMOs in order to conduct thorough environmental analyses. 
modified organisms had entered the country, and second, assuming that in that event, the government must regulate and control them, post facto. ${ }^{136}$ This became a central point of contestation within organizations mobilizing around the law. As history has demonstrated however, the manipulation, not only of the seeds in particular, but of the ecological environment in general is not only difficult, but also impossible in practice ${ }^{137}$ Regulating genetically modified seeds in particular, without modifying the agro-industrial capitalist process in general is not a sustainable solution to structural inequalities. Instead of structurally altering the ways in which production occurs and is organized, it becomes the responsibility of individual consumers to choose to purchase genetically modified seeds, which will be required by state to be labeled ${ }^{138}$ when entering into markets for consumption. For Licarion Soto of the CSUTCB, ticketing provides a way of controlling GMOs upon their entry,

...entonces, los transgénicos los que están ya están en soya, trigo, y también girasol pero a partir de esta ley ya no entramos no se podrían introducir. Pero, si introducen algún producto transgénico tiene que llevar el sello que diga como el cigarro el cigarro mata entonces este es un producto transgénico entonces el consumidor dirá pues consume o no consumo."139

Instead of the government taking a stronger and less-subjective position on genetically modified seeds by banning them completely, they have allowed for the entrance of seeds into the country which opens up a whole new arena of politics and possibilities for capitalist intervention mechanisms.

\footnotetext{
136 Article 19.5.

${ }^{137}$ See Araujo, Etnodesarrollo, Tierra Y Vida; and Villegas, Analysis of the LRPCA.

${ }^{138}$ Article 15.3. NB: This would also practically prove completely impossible. Bolivians still majorly purchase food in outdoor markets, which are sporadically spread out though rural and urban areas- the practical implications of a labelling campaign would only be possible in the context of supermarkets or grocery stores, which, then limits accessibly to a purely middle-class exercise of individual choice.

139 Interviewee was the secretary of Culture of the CSUTCB, and was a part of the internal working of the LRPCA. Interview took place September 9, 2011: La Paz.
} 
The LRPCA similarly attempts to define the parameters of genetically modified organisms in a way that attempts to consolidate campesino and indigenous memory of the seed technology packets introduced post-1985:

No se introducirán en el país paquetés tecnológicos agrícolas que involucren semillas genéticamente modificadas de especies de las que Bolivia es centro de origen o diversidad, ni aquellos que atenten contra el patrimonio genético, la biodiversidad, la salud de los sistemas de vida y la salud humana. ${ }^{140}$

Despite the fact that consumerism is central to neoliberal ideology, the MAS government continued to use it as a solution to GMOs within a law that was being called "antineoliberal. ${ }^{141}$ The "choice/consumerism" solutions were managed in order to garner and maintain consent within the middle class, whereas the "anti-neoliberal" discursive practices of the MAS were used to maintain hegemony within MAS supporters, primarily campesinos. People's memories of struggle against genetically modified organisms were not easily distracted, however, and the LRPCA became a clear target for civil mobilizations in June of 2011. This resulted in the re-surfacing of genetically modified organisms in the public arena for political debate and contestation. Thus, despite the MAS' attempts to pass the law without popular contestation, civil society mobilizations emerged in opposition to the LRPCA.

\footnotetext{
${ }^{140}$ LRPCA, Article 15.2.

${ }^{141}$ The government often uses neoliberalism as the point from which to differentiate their policies discursively and politically. Materially however, this tool has actually been quite effective in reproducing consent within the popular classes and maintaining the "not-neoliberal" image of the government while continuing to implement or permit the existence of past neoliberal policies.
} 
The issue of genetically modified seeds became central to the popular rejection of the LRPCA. In fact, CONAMAQ initially rejected the law simply on the basis of the articles, which would allow for the introduction of genetically modified organisms. ${ }^{142}$ According to Andrés Saavedra Vargas, authority of CONAMAQ, the government in "las últimas horas, y a su gusto, hasta lo que quieren se han metido los artículos 19,15 el numeral 4 , 5, 19 el numeral 3, esos artículos nosotros no queríamos que se apruebe, queríamos que abrogue el presidente, que dijeron que ellos, están equivocados. ${ }^{.143}$ CONAMAQ was not alone in the outright rejection of the possibility of GMOs. The organization for organic producers in Bolivia (AEOPEB), along with the Movimiento Sin Tierra (MST) as well as other varios civil urban institutions and organizations from Cochabamba and $\mathrm{La} \mathrm{Paz}$ actively took a role in taking up the fight against the LRPCA and transgenic seeds. ${ }^{144}$

Beyond the official statements of two of the five Pacto de Unidad Organizations (CIDOB and CONAMAQ), individual members within the other three signing organizations (Bartolinas, CSUTCB and Interculturales) expressed their concerns to me regarding the insertion of transgenic seeds into the law. According to Dora Martinez Colque, A Bartolina Sisa and founding member of the Asamblea y Soberania para el Pueblo:

...en los transgénicos también quiero decir, lo que he vivido, el transgénico a nosotros nos han afectado a través del tratado de libre comercio, así de clarito...entonces eso ahora estamos queriendo frenar, de acuerdo a lo que ya nos han hecho mal nuestras tierras, con esos fertilizantes ya no producen como antes

\footnotetext{
142 They later rejected it in its entirety.

${ }^{143}$ Interview took place July $15^{\text {th }}, 2011$ : Cochabamba.

144 These groups were part of the initial organizations that took a stand against the law, over the next few weeks following its rejection, other organizations like the CIDOB, and a group of intellectuals and activists in Cochabamba also took on the issue of transgenic seeds.
} 
han producido, y tal comiendo esa producción nuestros abuelos han vivido mas de 100 años, ahora eso ya no vivimos, nuestros hijos posiblemente, peor ya no van a vivir a nuestras edades, por que ya dicen me duele cualquier cosa, pero nosotros aunque todavía no nos duele, pero estamos ya consumiendo eso a través de esos transgénicos transportados de otros países, pero la misma materia prima que nosotros producimos, eso ya esta mezclado, ya esta fertilizado, así ¿no?, entonces no están trayendo de allá, si no para que no mezclen, asi de clarito tiene que ser, eso no vamos a permitir, eso vamos a poner a la mesa y discutir, que comemos, que debemos comer... ${ }^{145}$

For Dora, as for the majority of people I spoke and worked with regarding the issue of transgenic seeds, it was not simply a health issue, but it represented a much larger structural problem, a "free-exchange" one. ${ }^{146}$ For more than ten years indigenous and campesino organizations had been actively fighting and blocking the full implementation of transgenic seeds in Bolivia. As early as 2002, the CSUTCB and Bartolina Sisas were actively opposing ${ }^{147}$ the potential legalization of transgenic seeds in Bolivia. In a newspaper article published by them in 2005, Román Loyaza, the then head of the CSUTCB was quoted saying:

...no estamos de acuerdo con estos cultivos porque dañan la salud de los bolivianos, tampoco aceptamos el Tratado de Libre Cambio (TLC) con los Estados Unidos ${ }^{148}$ porque eso significa dar vía libre para que los productos transgénicos se produzcan en el país y también ingresen al mercado boliviano. ${ }^{149}$

\footnotetext{
${ }^{145}$ Interview July $15,2011$.

${ }^{146}$ Despite the fact that the middle and urban classes constantly attempted to frame the issue this way, I experienced this first hand in some of the meetings I attended at the CEDIB organizational networking meetings, where some of the urban organizations were focused on the health or environmentally destructive aspects of transgenic seeds, which emerged as a point of contention between the more radical organizations.

${ }^{147}$ Even though both of these organizations approved the LRPCA without modification when it was rereleased by the government.

${ }^{148}$ In 2004 the FAO (with collaboration from the US) recommended that the Bolivian state approve the use of transgenic seeds arguing that their implementation could benefit small-producers who do not have market access.

${ }^{149}$ Gina Mendia and Guisela Lopez, "Campesinos en Contra de Cultivos transgenicos.” El Deber (2005).
} 
Román highlights the potential private interests and thus dangers that would come with the modification and patenting of seeds. Colonisadora organizations, the CSUTC.B, AEOPEB, and the Bartolina Sisas, on numerous accounts were cited for their threats and actions directed against the introduction and regulation of genetically modified organisms. In fact, Evo Morales in 2002, with a group of campesino producers, lead various mobilizations and blockades against the possibility of legalization by the Gonzales Sanchez de Lozado government, leading to the stalling of the project for another year. ${ }^{150}$

With this history of opposition against GMO seeds, Bolivia's popular sectors had preexisting experience and knowledge of genetically modified seeds, ${ }^{151}$ and had been leading the fight, campesino and indigenous populations alike, for nearly a decade. The debate, which endured up until the election of the MAS government, continued to maintain central relevance with Evo making several international and national addresses against the legalization of GMOs. In 2006, he claimed "yo quisiera que en poco tiempo gritemos que Bolivia es un territorio libre de semillas transgénicas." ${ }^{152}$ Despite the insistence from the president at international climate conferences and UN meetings, it appeared as though transgenic seeds would be implemented in Bolivia. Several of the MAS ministers made public statements arguing for the absolute necessity of the legalization of transgenic seeds based on the rising food crises including Carlos Romero (also a member of the tri-

\footnotetext{
150 "“Transgenicos: Un Conflicto mas para el Congreso." El Deber. July 7, 2002.

${ }^{151}$ It is also important to note that the government on several occasions claimed that people simply did not understand the possibilities that transgenic seeds possess-nor did they understand that this was the only way in which the food crisis could be solved.

${ }^{152}$ As quoted in "Morales propone que Bolivia sea pais libre de transgenicos,"El Opinion, April 29, 2010.
} 
commission) who argued that "los transgénicos son necesarios para incrementar la producción y exportar mas."1153

Regardless of the MAS' previous position on genetically modified seeds, or the history of opposition from the campesino sectors of society, the LRPCA was approved without modification- the articles surrounding transgenic seed regulation included. ${ }^{154}$ Beyond the MAS' approval, the Bartolinas, Interculturales and CSUTCB all of whom previously expressed their rejection of genetically modified organisms signed off on the law's approval. ${ }^{155}$ As a response to an open letter written by 17 civil society organizations and institutions against the LRPCA, Carlos Romero, minister of the office of the presidency claimed that civil society misinterpreted the LRPCA and its positioning on transgenic seeds. He writes:

... hay una confusión...cabe aclarar que el articulo 15 de la Ley de la Revolución Productiva Comunitaria Agropecuaria al contrario de viabilizar los transgénicos, establece mayores limitaciones a las ya existentes (my emphasis)...con el fin de proteger nuestros recursos genéticos a los cuales hay que recuperar y aprovechar para beneficio a los bolivianas y las consideraciones presentes y futuras. ${ }^{156}$

\footnotetext{
${ }^{153}$ SOMOS SUR, Ley de la Revolución Productiva.

${ }^{154}$ The contradictions that are also quite clear in the MAS government's decision to introduce the issue of transgenic seeds into legislation echo the arguments made by the neoliberal governments attempting to do the same thing in the past. For example, the argument that claimed 'these organisms are already in the country and that we need to regulate them in some way' that was used several times by the Garcia Linera and Carlos Romero, also centrally framed the discussions in the early 2000 s which included headlines like "Transgenicos: ya estan en la mesa" and "[los bolivianos] se consumen alimentos geneticamente manipulados". Taken from: CEDIB, "Dossier Tematico: Transgenicos 2000-2011." CEDIB (Cochabamba: CEDIB, 2011)

${ }^{155}$ According to a Bartolina Sisa who has requested to remain anonymous, the issue of the approval of the law is a complex one. On the one hand the Bartolinas support the MAS ideologically, again many link this support to their experiences of struggle alongside Evo himself. On the other hand she argued, the Bartolinas have access to power, and thus resources, that before they did not. She continued to insist that GMOs would eventually be removed from the law, that it was a mistake that they had been approved to begin with. ${ }^{156}$ Ministerio de la Presidencia. Carlos Romero, "Carta de Repuesta a las instituciones de Cochabamba" (La Paz: Ministry of the Presidency, 2011).
} 
The reality is that there are some varieties of genetically modified seeds that have made their way into the country- the majority within cash crop and biofuel industries; many of which were introduced proceeding 1985 . Presently organizations like FONTAGRO, ${ }^{157}$ and Technoserve have open projects operating in Bolivia. FONTAGRO currently has 15 active projects in Bolivia; the majority of which make explicit claims to genetic modification and technological improvements of seed varieties, while simultaneously working towards consolidating "market logic" in campesinos (see Table III).

Despite this fact, we have failed to see a slowing down in the continued production of cash crops and oilseed industries, despite rising food and energy costs with the Morales administration. According to the FAO, total soya production in 2009 had reached $1,499,380 \mathrm{MT}$, which compared to the total soya production in 1999 is $35 \%$ more (see table I). In Santa Cruz specifically, soya production alone has increased over $90 \%$ between the years $2005-2010 .{ }^{158}$ That is to say that during the MAS government's presidency the production of soya, with transgenic seeds has increased significantly which has contributed to a strengthening of the regional oligarchy in Santa Cruz and the consolidation of transnational and regional capitalist interests through land-grabbing, social conflicts, and extreme environmental degradation.

\footnotetext{
${ }^{157}$ FONTAGRO is a regional agricultural research institute whose "alianzas estratégicas" include the World Bank, FAO, US Department of Agriculture, the International Food Policy Research Center (IFPRI), along with Bolivian partners like ANAPO. Technoserv, provides "business solutions to poverty" for smallproducers and agro-business. Their key partners include, the Bill and Melinda Gates Foundation, CocaCola, USAID, USDA and Cargill. http//www technoserve org/work-impact/locations/bolivia.hml

${ }^{158}$ Now, this was significantly aided by Mesa's decision to legalize the use of transgenic soy, which significantly aided the expansion of cash cropping of soya, and refining of soy into oil products.
} 


\begin{tabular}{|c|c|c|}
\hline \multicolumn{3}{|c|}{ Table III: FONTAGRO PROJECTS IN BOLIVIA 2011} \\
\hline Institution & Project & \begin{tabular}{|l} 
Details \\
\end{tabular} \\
\hline FONTAGRO & Technological Development for Small Business & $\begin{array}{l}\text { Works on strengthening } \\
\text { investigation and technology for } \\
\text { agricultural producers }\end{array}$ \\
\hline FONTAGRO & Opening up new markets for banana and plantain producers & $\begin{array}{l}\text { Improving economic conditions of } \\
\text { producers through efficiency skills } \\
\text { training }\end{array}$ \\
\hline FONTAGRO & 13 competitive Maiz zones in Latin America & $\begin{array}{l}\text { Providing appropriate training and } \\
\text { technology for making countries } \\
\text { competitive in maiz production }\end{array}$ \\
\hline FONTAGRO & $\begin{array}{l}\text { Tomato Tree: A Promising product for the diversification of } \\
\text { Andean production. }\end{array}$ & $\begin{array}{l}\text { Technological collection of } \\
\text { specimen for modification to allow } \\
\text { for industrialized production }\end{array}$ \\
\hline FONTAGRO & Strengthening the frontier production of potato & $\begin{array}{l}\text { Varying production based on } \\
\text { climate change }\end{array}$ \\
\hline FONTAGRO & Reducing agricultural vulnerability in the Southern Cone & $\begin{array}{l}\text { Technological and political } \\
\text { strategies for minimizing } \\
\text { vulnerability in Southern Cone } \\
\text { agricultural production } \\
\end{array}$ \\
\hline FONTAGRO & $\begin{array}{l}\text { Development and valuing of genetic resources for stress } \\
\text { reduction due to climate change }\end{array}$ & $\begin{array}{l}\text { Genetic modification of varieties } \\
\text { of Potato }\end{array}$ \\
\hline FONTAGRO & $\begin{array}{l}\text { Improving market competitiveness for Amazonian fruit } \\
\text { production }\end{array}$ & $\begin{array}{l}\text { Improving competition, training } \\
\text { and strategies }\end{array}$ \\
\hline FONTAGRO & $\begin{array}{l}\text { Development and Application of ecological production } \\
\text { practices to increase production of potato }\end{array}$ & Plague management \\
\hline FONTAGRO & $\begin{array}{l}\text { Technological innovation and new market orientation for } \\
\text { potato production }\end{array}$ & $\begin{array}{l}\text { "Innovation" in native potato } \\
\text { varieties }\end{array}$ \\
\hline FONTAGRO & $\begin{array}{l}\text { Improving community nutrition using fortified maiz and } \\
\text { beans. }\end{array}$ & $\begin{array}{l}\text { Seed substitution using vitamin- } \\
\text { enforced seeds }\end{array}$ \\
\hline FONTAGRO & Genetic resistance in maiz & $\begin{array}{l}\text { Modification for resistance to pests } \\
\text { and disease }\end{array}$ \\
\hline FONTAGRO & $\begin{array}{l}\text { Selection and strengthening of pest-resistance varieties of } \\
\text { potatoes for industrialization }\end{array}$ & $\begin{array}{l}\text { Industrialization of Andean } \\
\text { varieties of potato }\end{array}$ \\
\hline
\end{tabular}

Coinciding with the increase in production of soy, deforestation rates have also increased exponentially. According to the 2009 Atlas de Potencialidad Productiva, the rate of deforestation from 1986-2005 has been $36 \%$ in the Integrated North of the department of 
Santa Cruz (where the majority of the forest is located), with the average deforestation rate predicted for the coming years to hover around $1-2 \%$ per year. ${ }^{159}$ The report continues to outline the ways in which deforestation can be attributed to the expansion of agricultural production:

Es importante resaltar que la tendencia anual de deforestación estaría entre $1 \%$ y 2 $\%$, y de mantenerse así, en 15 o 30 años más no habría cobertura de bosques en el área de análisis. De acuerdo a lo descrito, párrafos arriba, se puede establecer que el área seleccionada de análisis representa claramente el crecimiento del sector agrícola del departamento de Santa Cruz. ${ }^{160}$

In Bolivia, agro-industrial production has led to significant deforestation levels. This deforestation is so significant that it cannot simply be attributed to small-scale slash-andburn production, rather by large-scale agro-industrial production that simultaneously profits from the short-term gains of wood and soy industries, and then longer-term cattle ranchers. In a recent article published by Erbol, the three main causes for deforestation are listed sequentially, with subsistence farming listed as the first cause, to be followed by mechanization and agro-industrial production, and finally cattle grazing. However, the article proceeds to outline the ways in which soya production in the 1990 's and 2000 's "coincidió con políticas que favorecieron el sector privado, inversiones estratégicas en infraestructura y condiciones de mercado favorables para la soya."161

Several times during my fieldwork news coverage would focus on forest fires that would arise in Santa Cruz, attributing their causes to campesinos clearing their fields, failing to

\footnotetext{
159 Ministerio de Desarollo, Atlas Productiva.

${ }^{160}$ Ibid.

161 ERBOL. "Estudio revela 5 millones de hectáreas de bosque deforestados en 3 décadas." Periodico ERBOL, January 14, 2012.
} 
recognize the other ways in which deforestation rates are climbing as a result of the immensely expanding cash-cropping industry in the same department.

This cycle of deforestation-industrial production- ranching provides us with the central importance of land to maintaining economic and political power in the crucena region. ${ }^{162}$ It also allows for financial speculation practices, and has been achieved by the continued existence and maintenance of agro-industrial land that was untouched by the Agrarian Reform, or obtained illegally during the massive land gifting in the 1970's and 1980's. This is something that I will explore in the chapter that follows.

MAP II: Forest Coverage in 1986 and 2005, SANTA CRUZ
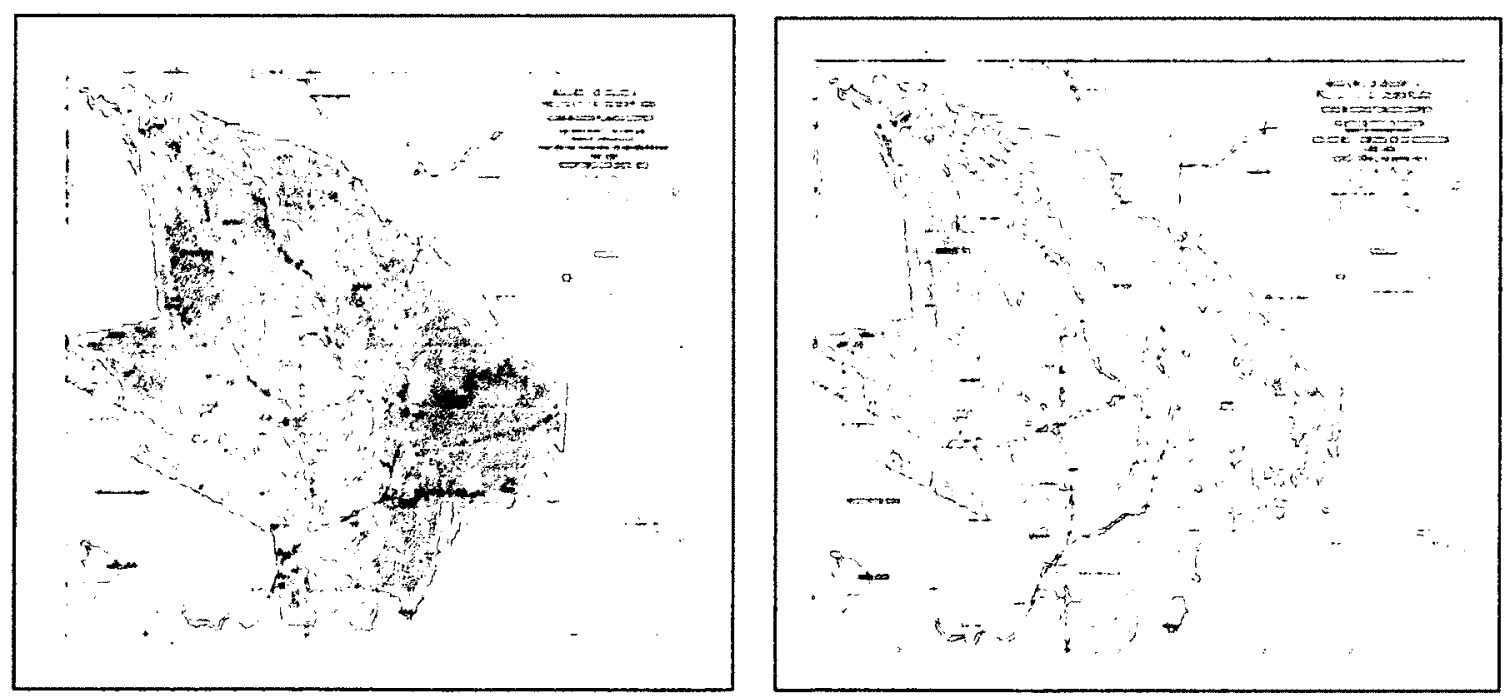

${ }^{162}$ Fabricant, "Ocupar, Resistir, Producir." 
It is clear then that genetically modified seeds represent not solely a segment in the chain of production but yet that they represent a means through which neo-imperialist capitalist extraction occurs in agricultural production in Bolivia. They also present us with a clear example of the contradictions within the NCPE and the LPRCA, which now simultaneously tout protecting the environment while continuing to enable exploitation of resources and people at the behest of the capitalist class.

Aside from the risks of eliminating the diverse variety of species and expansive deforestation that industrialized agriculture can bring, it is important to clarify the political and economic implications. Industrialized production-for-export using cash crops like soya does not solve the "hunger problem." In fact, as we saw, imports are still high for consumption products like wheat, while Bolivia continues to produce products that are not primarily consumed in Bolivia. Second, industrialized production for exportation purposes means that agricultural production is tied to the boom-bust price cycles of the market, which, in the context of an increasing energy crisis, means that the country becomes even more vulnerable with an industry that is bound to energy consumption for its production, like we saw in the 70s and 90s. Finally, with the expansion of the agro-industry and the proceeding destruction of arable land, campesinos and indigenous communities are left with what is left over, making the possibilities for small-scale, sustainable production, and thus "food sovereignty", impossible.

Now that the economic and political interests of the LRPCA have been defined, I will explore the ways in which land and land tenancy has failed to be adequately accounted 
for and dealt with by the MAS administration which will, I argue, severely restrict the possibilities for the development of sustainable, small-scale campesino production. 


\section{Chapter 3: La Via Campesina, or the Industrial Route?}

On January 22, 2012, Evo Morales and Alvaro Garcia Linera gave the Informe a la Nacion, an overall economic and political review of the past year. In this address, Morales claimed that the Social Economic Function of Land (FES) would be paralyzed for five years. ${ }^{163}$ The FES has been a mechanism put in place to prevent (or at least maintain) large-landholdings and financial speculation which inhibit the inversion of funds into the country and thus into national social and economic development. During his speech he continued on to argue that "el pequeño productor con el agroindustrial siempre estaban enfrentados, lo que nunca los dos sectores acuerdan sobre la FES...esperamos que esta pausa sea para dar utilidad a la tenencia de la tierra de los empresarios, vamos a respetar pues es importante para fomentar la producción de alimentos." ${ }^{164}$ In the Law 1715 INRA it is outlined that all medium and large properties are subject to state revision to ensure that their property fulfills a social-economic function every two years. That is to say that property must contribute to the social and economic development of Bolivians collectively, in a way that is environmentally and economically sustainable. ${ }^{165}$ This mechanism is extremely important for limiting exploitation of labour, land-grabbing and financial speculation (to name a few). ${ }^{166} \mathrm{Its}$

\footnotetext{
${ }^{163}$ At the annual cumbre nacional land was discussed in two real ways. The first was the suspension of the 5-year FES revision and the second regarded TCOs. With regards to the FES, agricultural producers proposed the demand that they wanted "flexibilized land tenancy," with the president of the CAO of Santa Cruz claiming that Santa Cruz was responsible for $72 \%$ of the agricultural production of "food". From Ivan Cordovi. "Los agropecuarios piden flexibilizar la tenencia de la tierra." La Razon, January $5^{\text {th }}, 2012$. ${ }^{164}$ Fundacion Tierra, "El Presidente anunció la paralización de la Función Económica Social (FES)." Fundacion Tierra, $22^{\text {nd }}$ of January, 2012.

165 Law 3545.

${ }^{166}$ On December 28, 2011 the newspaper El Deber announced that 98 Crucena businesses has not paid their end-of-the-year bonus as required by law, which accounted for $1 / 3$ of businesses who had failed to do so in
} 
suspension for five years will allow for medium and large landholders to continue with poor environmental and labour practices without being subjected to possible review. ${ }^{167}$

This, however, was not the first move taken by the MAS government to allow for the perseverance of large-landholdings in Bolivia. Since the election of the MAS in 2006, land distribution has increased, especially the re-distribution of land to indigenous communities as Territorios Communitarios de Origen (TCOs) through the Ley de Reconduccion Communitaria 3545. Upon stating this however, this re-distribution of land often has come out of state or fiscal land. This as opposed to working to dismantle the industrial agricultural production system in the lowland crucena region (with the majority of TCOs being of poor quality and quantity failing to adequately meet their subsistence needs) ${ }^{168}$ leaves the elite crucena economic power essentially untouched.

Inequality among those who have land and those who do not is astronomical. In Bolivia approximately 400 individuals own 70 percent of productive land while there are 2.5 million landless peasants. ${ }^{169}$ Even when the violent political eruptions occurred in 2008 with cruceña elites attempting to overthrow Evo failed, and their political power destabilized "... sin embargo, la base material de su poder conservado, la tierra bajo

the country. Although the article did not outline which businesses had failed to do so, since agriculture accounts for the majority of economic activity we can assume that some of those practices occurred within the agricultural sector.

167 This was the MAS' modification to the 19961715 Ley INRA. See Fabricant, "Ocupar, Producir, Resistir"; and Medeiros, Evolucion y Caracteristicas del Sector Soyero.

168 Ormachea, Revolucion Agraria o Consolidacion.

169 Wes Enzinna, "All We Want is the Earth: Agrarian Reform in Bolivia," in Leo Panitch and Colin Leys (eds) Socialist Register 2008: Global Flashpoints, Reactions to Imperialism and Neoliberalism, 2007. 
forma latifundiaria y destinada al negocio inmobiliario, todavia se mantiene. ${ }^{170}$ Their power has been maintained, due in part to a large constitutional loophole, permitting the holding of plots of land exceeding 5,000 hectares. Large landholdings still continue to maintain about 90 percent of Bolivia's productive land, with only 10 percent divided between mostly-indigenous peasant communities and smallholding peasants. ${ }^{171}$

Originally when the CPE was developed in conjunction with the Pacto de Unidad in 2003 , it was decided that no one, by any means, could have landholdings larger than 5,000 hectares. Again, this was the product of the collective decision-making and production of the CPE. After the CPE entered into the bureaucratic phase of its life, the phase of state revision; articles 315 and 398 were inserted which eliminated the 5,000 hectare limit. This implied that Bolivia would have no maximum land tenancy. That was before the MAS took presidential power.

With the approval of the referendum of the MAS' NCPE in 2009 the MAS, clearly pressured by the crucena elite, failed to correct this loophole. Similarly they failed to address the growth of land holdings by agroindustry, which has lead to growing discontent amoung campesino and indigenous communities. For Urioste, the concession which would primarily benefit the landholding class in Santa Cruz "fue el precio que el gobierno de presidente Morales tuvo que pagar a cambio de la aprobacion de la convocatoria parlamentaria por dos tercios, para realizar la aprobacion de la NCPE en

\footnotetext{
${ }^{170}$ Ibid, 19.

${ }^{171}$ Walter Chavez and Álvaro Garcia Linera, "Rebelión Camba: Del dieselazo a la lucha por la autonomia", El Juguete Rabioso (2005).
} 
febrero de 2009 y asi viabilizar su continualidad en el gobierno..."172 With the approval of the NC.PE the MAS enabled the expansion of agro-industry, first by making landholdings not retroactive (which meant that those who did hold large land plots simply had to prove their FES), ${ }^{173}$ and second that in Article 315 the state would guarantee that all partners of a corporation or all family members would be permitted to hold 5,000 hectares as long as it met the requirements of generating employment and commercializing goods and services. ${ }^{174}$

The MAS government then, has failed to break away from the neoliberal politics of the past "porque se considera central para el desarollo del pais la presencia del capital extranjero y la gran empresa nacional en la explotacion de los recursos naturales."175 The government is opting instead to promote the protection of individual private property and the expansion of the agro-industry, which, as we have seen, produces cheap cash crops primarily for export. Further, in February, the government announced that nearly $10 \%$ of the country's international reserves would be inverted into productive development in agriculture through the Fondo para la Revolucion Industrial Productiva (FINPRO). According to the Vice-president of the Cámara Nacional de Exportadores de Bolivia (CANEB), Guillermo Pou Mont "el Fondo debería ser el de las oportunidades para los emprendedores, para que puedan desarrollar no pequeñas empresas, sino medianas y

\footnotetext{
${ }^{172}$ Urioste, Concentración y extranjerización de la tierra, 26.

173 Articles 398 \& 399.

174 Ibid.

${ }^{175}$ Ormachea, Revolucion Agraria o Consolidacion, 108.
} 
grandes, porque el futuro está en los mercados de exportación."176 This again emphasizing the importance of industrialized production for export, which as we have seen time and time again, further subjects farmers to the precarity of international food prices, cheap food stuff imports, and increased poverty and marginalization.

\subsection{The Campesino - Indigena Question: pequeños productores, economía plural, and the dangers of romantisizing the local}

...todos esos temas que dicen de los compañeros, también comparto toda la estructura de

la comunidad que esta basado en solidaridad, en trabajo comunitario; se va a destruir, por que se esta imponiendo a la comunidad un sistema económico en base a unidades económicas, entonces no se esta valorando eso. Helga Cauthin, MST-Mujeres

Another potential danger of the LRPCA is the way it emphasizes the importance of strengthening 'community-based production.' The problem lies in the ways in which the community is envisioned as social and communal land ownership, production and redistribution for subsistence and national markets, as opposed to family-unit individual land ownership with the objectives of production for profit. There is a recent tendency, one which I would argue coincides with the neoliberal off-loading and rolling-back of states, of romantisizing the local- which has coincided with indigenismo politics. These two trends combined have contributed to the ways of imagining alternatives within

\footnotetext{
${ }^{176}$ W Chipana, "El Finpro financiará a 22 sectores para asegurar alimentos y empleo," La Razon, February $15 \mathrm{th}, 2012$.
} 
capital. Alternatives which, as we have seen can co-exist and even strengthen capitalist models of surplus extraction.

In addition, if as many studies in Bolivia have shown production is communally and socially organized amoung indigenous communities ${ }^{177}$ (particularily in the lowland region) then we can make the claim that indigenous production still maintains some forms of communist forms of production. Simultaneously these forms of production exist within (and interact with) complex systems of agricultural campesino production which has developed from state-encouraged farmer production, and large-scale agro-industrial production.

As Spedding reminds us in her studies comparing coca production in the Yungas and Chapare regions, often the lines between communal/individual, public/private are blurred depending on the precarious nature of production in Bolivia, be it through constantly fluxuating market prices, extreme weather conditions, geographic isolation, property access, etc. ${ }^{178}$ Further, those distinctions vary within "indigenous" and "campesino" communities. I do not, then, wish to make the claim that indigenous communities continue to produce for subsistence and campesino communities for markets. That is a simplification that is void of its political and economic context despite the fact that it figures heavily into the ways in which tensions have emerged, catalyzed and in some ways been manipulated in order to fracture the collective solidarity within the subaltern

\footnotetext{
${ }^{177}$ See Arajo, Etnodesarrollo, Tierra Y Vida; Margerita, El Poder de la Tierra; Schutze, llameros y Caseros; and Soliz \& Aguilar, Produccion y Economia Campesino-Indigena.

${ }^{178}$ Spedding, Kawasachun Coca.
} 
classes. In fact, with the large land gifting to lowland indigenous groups through TCOs by the MAS government over the past few years, conflicts between "indigenous" and "campesino" groups have begun to re-surface. For Urioste, "Como efecto de la titulacion de grandes territorios de pueblos indigenas, especialmente a los de tierras bajas, se han aguadizado conflictos entre los campesinos y los indigenas por el aceso a la tierra y control del teritorio." ${ }^{\prime 79}$ The fact remains that there are still large numbers of campesino and indigenous communities that do not have access to land. ${ }^{180}$ These internal popular sector stuggles allow for distraction from the ways in which the MAS politics have continued to protect the land-holding class in Bolivia. The follow two chapters will focus on this fracture, the objective at hand however, is to focus on the ways in which the MAS' communitarianism ${ }^{181}$ is being used to propagate capitalist development, further destroying possibilities for collective organization of land and resources and the socialization of the means of production.

As we saw with the popular Revolution in 1952, armed campesino militias began expropriating haciendas in the highland and valley regions. This impulse was then absorbed into the MNR state apparatus, which released the Agrarian Reform to redistribute land to individual and family campesino land holdings in the event that they were unidades productivas. Combined with the increased colonization of the lowland region, campesino communities began to grow in number but also in political power. As

\footnotetext{
179 Urioste, Concentración y extrunjerización de la tierra, 19.

${ }^{180}$ Recent "illegal" land expropriations by campesinos in Santa Cruz reveal this very fact. The government's reaction was to protect private property for the landholders and remove the campesinos from the land. See Fabricant, "Ocupar, Resistir, Producir."

${ }^{181}$ Ormachea, Revolucion Agraria o Consolidacion.
} 
we saw in chapter one, the objective of the Reforma Agraria of 1953 was not to encourage small-scale socialized production, rather to encourage farmer based capitalist production which, although uneven, resulted in increasing polarization of power and wealth within campesino-indigenous communities. It is absolutely essential that we remember the core base of the capitalist mode of production, the individual right to hold property. The central role of the MNR government and later IFIs became then to protect, facilitate and maintain private property ownership. Their encouragement of parceled production lead to some campesino and indigenous families and majorly the agroindustry accumulating wealth at the expense of continued impoverishment of the majority of Bolivians.

Bolivians often refer to a socialist or communist vision for the future, when referring to the ways in which they want to see the proceso de cambio develop so that all Bolivians are able to "vivir mejor." The MAS government on countless occasions talks about the potentialities of combining the andian cosmovision with "other" modes of production. Since the idea of the "community" has become reified through its romantisization- it provides the appearance of the possibility or expansion of indigenous socialized production through these strategic partnerships with capital. For Soruco,

...esta relación disímil, antagónica, en ultima instancia, solo sirve a los intereses de la reproducción del sistema capitalista $\mathrm{y}$, desde luego, conduce a un mayor desintegración de las comunidades indígenas, proceso que el Estado neoliberal impuesto en el país las ultimas del siglo XX acentuo notoriamente ${ }^{182}$

182 Soruco, "De la Goma a la Soya," 49. 
When the MAS government propagates the communitarianization of agricultural production then, this resonates among the popular classes in two ways. First, among those who form part of the nationalist project which seeks to unify the popular classes against neoliberal, capitalist and colonial forms of exploitation. ${ }^{183}$ Second it resonates among those indigenous communities that live in the lowland regions where autonomy resonating with a history of geopolitical isolation has lead to a rejection of the colonial state apparatus and thus a move towards self-governance. ${ }^{184}$

So, when the LRPCA emerged following the "Bolivia Digna, Soberana, Productiva $y$ Democrática Para Vivir Bien" national economic plan, the promotion of the community resonated with common-sense. It also, however, revealed key tensions between the economic-political tendencies of the government and the ideological representations of those policies. Thus being, that despite what the government was claiming to deneoliberalize and de-colonize production was not present in practice. The LRPCA provided a clear example of those emerging contradictions.

According to Victor Comacho, when the LRPCA emerged from the revisionary tricouncil completely changed, not only in form but also in spirit. For Comacho,

...[los ministros] se involucro mas, y creo que generaron una propuesta, pero a mi juicio, con otra visión digamos, que es la revolución productiva, ¿no ve?..El seguro agrario indígena originario campesino es una deuda histórica del estado, a lo que es economía indígena originaria campesina. Entonces, no puedes actuar con la misma lógica de cualquier tipo de seguro, ¿no? Dentro marco occidental, neoliberal, etc. No es posible. Un seguro agrario es como un seguro de salud, ¿no ve? donde el estado asume su responsabilidad pública con ese sector. Entonces,

\footnotetext{
${ }^{183}$ Luis Tapia, La Coyuntura de la autonomia relativa del estado (La Paz : Muela del Diablo, 2007).

${ }^{184}$ Ybarnegaray. El Espiritu del capitalismo.
} 
elaboramos una propuesta de seguro agrario, yo lo elaboré y tenía esas bases, digamos, ¿no? Bueno, entonces la Década iba por un lado y la Revolucion Productiva era otra propuesta no estaban vinculados...

Here, Comacho identifies the obligations that the Bolivian state has to encourage and strengthen community production and that support should be provided universally and without question, food production should be socialized. But he is also making a statement that reflects a much larger contradiction within the NCPE, and Bolivia's Economic Development Plan. The contradiction is the idea of a harmonic balance, not only between nature and people but also between capitalism and community production, the "economía mixta." Lic Gonzalo Vargas Rivas, ${ }^{185}$ coordinador de autonomias departamentales de Cochabamba, similarily echoed Comacho's concerns with regards to the possibilities of the LPRCA:

Con lo que mi temor como servidor público, es que esta ley vaya dando mas pábulo, vaya dando mas cuerpo justamente a una economía... a una forma de organización económica para la producción, que ha ido arrinconando la economía comunitaria y que es coherente con esto que el presidente Evo Morales permanente dice, "Defensa de los derechos de la Madre Tierra", no es cierto. O sea, la economía capitalista, el modelo de intercambio y la acumulación, es adversa a los derechos... en defensa de los derechos de la Madre Tierra. Y ahí ya vamos un poquito en ciertas contradicciones de nuestras políticas publicas, a no ser que vaya a complementarse esta ley con unas acciones que provengan de los pueblos indígenas, que revitalicen y fortalezcan sus estrategias de producción económica comunitaria. Por que el vivir bien, no es una consigna, el vivir bien justamente establece los criterios básicos de esa economía comunitaria. ¿Por que? porque las lógicas de redistribución y reciprocidad implican una adecuada relación de la sociedad humana, con el medio ambiente, con la naturaleza. Si no vamos a poder vivir bien, si estamos afectando el medio ambiente, si estamos afectando la naturaleza, entonces por eso se dice vivir bien, por que tiene una esencia comunitaria. En cambio, mejorar las condiciones de vida es parte de la lógica capitalista, uno puede mejorar sus condiciones de vida independientemente de que la mayoría de la gente se empobrezca, independientemente de que estamos afectando y esquinando el medio ambiente, ¿no es cierto? Entonces, esa es la

\footnotetext{
${ }^{185}$ He requested that I emphasize that this statement does not reflect the official position of the municipality of Cochabamba, nor of his office, but rather reflects his personal opinion based on his experiences working with indigenous communities.
} 
diferencia sustancial, por tanto, creo yo, que la ley de la Revolución Productiva Comunitaria si bien va a tender aspectos y requerimientos de los pequeños productores campesinos, pero, lo que esta haciendo en el marco, o sea... en mayor proporción en el marco de lo que son las lógicas del intercambio y la población capitalista.

In Decreto Supremo No. 29272, the legal document introducing the National

Development Plan "Bolivia Digna, Soberana, Productiva y Democrática Para Vivir Bien" the MAS outlines the importance of finding a balance, or armonia, between capitalist and non-capitalist, public and private interests:

Desarrollar la convivencia equilibrada y la complementariedad con equidad de la Economia Estatal, la Economía Comunitaria -que se asienta en procesos productivos, impulsados por organizaciones sociales, comunitarias, y micro y pequeños empresarios, artesanos, organizaciones económicas campesinas, organizaciones productivas, comunidades y asociaciones urbanas y rurales-, la Economía Mixta y la Economía Privada. ${ }^{186}$

Similarly, in the LRPCA, it is emphasized that, instead of actively working towards dismantling private production or capitalist production the law identifies the economia plural as "las distintas formas de organización económica existentes en el país, compuesta por las formas de organización económica comunitaria, estatal, privada y social cooperativa" 187 which the law continues to confirm that food sovereignty: ...se sustenta en la concurrencia de todos los esfuerzos, iniciativas, principios y políticas del Estado, las naciones y pueblos indígena originario campesinos, comunidades interculturales y afrobolivianas, otros actores de la economía plural y la población en general, quienes actuarán conjuntamente para la satisfacción de las necesidades alimentarias de las bolivianas y los bolivianos. ${ }^{188}$

The capitalist model of agricultural development does not have the primary goal of achieving food sovereignty or food security. The primary objectives of the capitalist

\footnotetext{
${ }^{186}$ Article 5.4.

${ }^{187}$ Article 7.5.

${ }^{188}$ Article 7.2 .
} 
system are to extract surplus, and maximize surplus production. The displacement of indigenous and campesino communites into the larger workforce, and the incorporation of more labour into the already bloated workforce enables the further expansion of capitalism. Further, the maximization of a capitalist industrial mode of agricultural production simultanesouly makes national production for consumption difficult and subordinates bolivia's position to regional and international food prices and production and geopolitical agendas.

When the MAS refers to the communitization of the Bolivian economy, they are actually in practice, seeking to further expand small-scale capitalist development into campesino communities. In the LRPCA, OECOMS (Organizaciones Economicas Comunitarias) are recognized as "comunidades indigena orginario campesinas, comunidades interculturales y afrobolivianas, como Organizaciones Economicas Comunitarias- constituidas en el nucleo organico, productiva, social y cultural para el vivir bien." ${ }^{189}$ Communities are recognized as economic units whose objective is in fact to produce for market. For Ormachea , "esta medida [comunitizacion] profundizara los procesos de diferenciación campesina en las comunidades."190

On February 5, 2012, CAINCO proudly announced the new registration of 251 new businesses (six month period) thanks to the campaign they launched called "CAINCO Soya." The program, which encourages a production-for-profit model of agricultural production, encourages not only the movement of farmers away from subsistence farming

\footnotetext{
${ }^{189}$ Article 8.

${ }^{190}$ Urioste, Revolucion Agraria o Consolidacion, 90.
} 
to market production, but does so through encouraging the production of the cash-crop, soy. Since soy production renders the producer entirely subject to foreign market fluctuations, raising costs of chemical inputs, and the movement away from producing food-for-consumption it is a clear indicator of the contradictions of the "strengthening" of the community, through community-business. The reference to and use of "community" merely propagates the expansion of capital and the further destruction of communal organization of land and production. Although distinct, the MAS' policies have continued to promote capitalist development in ways that echo with those capitalist and colonialist policies of the past.

\subsection{The LRPCA and the two sides of the capitalist coin}

The first half of this project centered on ways in which the MAS are encouraging farmer/campesino production without adequately redistributing land, or dealing with the latifundio system that still exists. We cannot forget however, the core foundation necessary for the capitalist mode of production, the right to hold private property. Really, the MAS has continued to protect the rights of large landholders to hold property and accumulate wealth, while simultaneously encouraging individual and now communitybusiness private property.

The political-economic relations I have revealed in previous sections demonstrate the ways in which the LRPCA is constrained and limited by the larger economic and political movements at play. The LPRC.A continues to encourage capitalist industrial production- 
through the promotion and appropriation of imagined indigenous values like "community" to propagate a small-scale capitalist farmer model of production while simultaneously encouraging (or neglecting) industrial cash cropping and permitting the expansion of land grabbing, and agro fuel production.

Between and beyond the rhetoric of the LRPCA lies the forgotten but clearly central issue of land and property which being similar, but not exact to the MNR Reforma Agraria has failed to adequately address the largest and most detrimental factor to both campesino and indigenous production and subsistence: access to and control over resources. The persistence and expansion of the agroindustry system in the lowland region, particularly in Santa Cruz is continuing to an exacerbation of human and environmental impoverishment in order to maximize short-term surplus extraction- and at the expense of near mit'a like working conditions ${ }^{191}$ in a country where even child entertainers have unions. ${ }^{192}$

The political relations are those which I will explore in the remaining sections, the ways in which the popular classes, the majority of Bolivia's poor (which according to the latest world bank statistics is the vast majority of the country) are continuing to fragment between indigenous and campesino while the larger political project or the proceso de cambio is being lost in the process. Instead of a decolonization and socialization of the

\footnotetext{
191 Fabricant, "Ocupar, Resistir, Producir."

192 When living in the vigil, twice a week until the conflict was resolved the child entertainers dressed up as clowns would come to the vigil to express solidarity with the TIPNIS. Holding their union shield they would march around cheerfully chanting "¿Que queremos? ¡Pronta Solucion!" calling for peace for the children of the TIPNIS. This is a subtle yet beautiful example of some of the accomplishments that the labour movement has succeeded to achieve in Bolivia, and also exemplifies the ways in which workingclass alliances, even child entertainers, emerged in solidarity.
} 
means of production, we are seeing a re-emergence of racialized tensions between the lowland indigenous "salvajes" 193 and the modern campesino and colonizadores populations, which surfaced and became particularly salient during the TIPNIS conflict but have continued to bubble with the Pacto de Unidad split.

These fractions, however, are also contributing to a re-mobilization of politics and emerging strategic alliances between historically distinct sectors. The dangers of the popular class divisions, and the re-colonization of politics within the 'have-nots' is that the popular bases that unified to remove the neoliberal and fascist governments of the past are splitting. This is leaving room for the political and economic elites of the country, particularly in the lowland regions, to re-mobilize and re-organize to provide and manipulate the politics of possibility for Bolivia. The political implications can thus be put much more simply: while the popular classes are negotiating and manifesting conflict from within, the right wing and regional geopolitical interests are patiently awaiting the eruption. ${ }^{194}$

The LRPCA and later the TIPNIS conflict reveal the interactions, manifestations, and contestations that emerge in particular moments to shed light on larger political processes, tendencies and motives. As such, the previous three chapters have provided the foreground necessarily for analyzing the ways in which these particular "moments" manifested a much larger and broader economic and political history- the terrain of

\footnotetext{
193 On September 72011 , Roberto Coraite the president of the C:SUTCB in a national press conference referred to the indigenous marchers as "salvajes" who were impeding on the development of the nation. ${ }^{194}$ Kirsten Francescone, "Internal Fractions and the right in Bolivia," The Bullet 548 (2011).
} 
struggle. The following two chapters will explore the development of politics and its possibilities for the proceso de cambio in Bolivia. 


\section{Chapter 4: The Complexities between "The State" and "Civil Society"}

The previous sections have been set out to lay the foundation for the analysis of the ways in which popular mobilization against the LRPCA and later the TIPNIS conflict can be seen as products of, but also contributing to a re-mobilization of social movement politics and a rupture in the political conjuncture.

The section that follows will explore the Pacto de Unidad and the ways in which it has served to simultaneously de-mobilize and re-mobilize popular political organizing. In this section I will explore the emergence of the Pacto de Unidad and explore some of the key tensions that have continued to surface with regards to its institutionalization. Here I will draw primarily from observations and conversations collected during my fieldwork regarding the questionable approval of the LRPCA by the majority of the Pacto de Unidad organizations and the TIPNIS conflict which as a moment represents a much larger rupture in the political conjuncture in Bolivia at present.

\subsection{Popular (?) political participation and the Asemblea Constituyente}

Las naciones y pueblos indigenas originarios y campesinos hoy tenemos el desafio de participar en la refundación de Bolivia, construyendo un nuevo país fundamentado en los pueblos como sujetos colectivos, hacia la construcción de un Estado Plurinacional, que trascienda el modelo de Estado liberal y monocultural cimentado en el ciudadano individual.

Pacto de Unidad, $2006^{195}$

\footnotetext{
${ }^{195}$ As cited in: Pablo Reglasky, "Political Processes and the Reconfiguration of the State in Bolivia," Latin American Perspectives 172 (2008).
} 
In order to understand the Pacto de Unidad, it is essential that we move back to the indigenous and popular mobilizations of the 1990's and the demands for a new Asamblea Constituyente as the foundation for the national-populist mobilizations that escalated to expulsion of the neoliberal governments in the 2000's. These uprisings propelled the popularized unification of popular, indigenous and urban sectors, which lead up to the election of the MAS in $2005 .{ }^{196}$ These mobilizations raised, along with the large lowland indigenous mobilizations of the nineties, ${ }^{197}$ the idea of the reconstruction of the Asamblea Constituyente continued to gain momentum. The Asamblea Constituyente viewed as the ultimate response to demands for the cultural, economic and political decolonization of the nation was based on a culmination of extreme colonial marginalization. Marginalization of indigenous people politically and economically, and compounded by the neocolonial dismantling of industry and the public sector following $1985,{ }^{198}$ indigenous and national-populist sectors looked to the reconstruction of the Asamblea Constituyente as a way of practically implementing their vision. Their vision was two fold and enabled a mergence of the national-popular and indigenous political imaginary, de-colonization of the state, and anti-neoliberalization. ${ }^{199}$

\footnotetext{
${ }^{196}$ Both Diaz and Tapia argue that these are key points in a historical development of popular-national mobilizations that emerged to propel the Asamblea Consituyente. For the purposes of this paper, it is unfeasible to enter into a historic development of the history of popular mobilization, suffice it to say for the moment that what emerged in the $90 \mathrm{~s}$ is the product of a historical process of exclusion and resistance by the popular and indigenous classes. See: Vladimir Diaz, Critica de la Teoria del Poder Constituyente: Los Limites del Proceso Constituyente Boliviano (La Paz: Instituto de Investigacion, Capacitacion y Formacion Democratica "Carlos Montenegro", 2008); and Tapia, La Coyuntura de la autonomia relativa clel estado.

197 The Indigenous march "por la Asamblea Constituyente, por la Soberania Popular, el Territorio y los Recursos Naturales" posited state-reform with the demand of a new Consituyent Assembly. See: Chavez \& Mokrani, Los Movimientos Sociales en la Asemblea Constituyente, 109.

${ }^{198} 1985$ marked the official neoliberalization of the Bolivian Economy with Estenssoro's "New Economic Plan."

199 See Oscar Olivera and Raquel Guitierrez, Nosotros Somos la Coordinadora (La Paz: Fundacion Abril, 2008); Tapia, La Coyuntura de la autonomia relativa; and Jeff Webber, From Rebellion to Reform in
} 
Several Bolivian scholars have analyzed the possibilities and limitations of the Bolivian Constitution as the site for revolutionary change. As early as 2007 , scholars were questioning the possibilities of revolutionary change within the parameters of the Constituent Assembly. According to Diaz, (in his analysis of the possibilities and limitations of the new constituent assembly) the Asamblea Consituyente "marcaba una consigna democrática, un mecanismo para reparar la histórica exclusión de las mayorías indigenas del pais." ${ }^{200}$ However as Diaz continues to argue, the possibilities for decolonization and the development of a plurinational state are in fact constrained by the economic and political structures that failed to be challenged with the MAS' reorganization of the state apparatus. ${ }^{201}$ Diaz maintains that the new constitution merely represents a re-organization of political power whilst the economic structures, liberal capitalist structures, remain intact.

For Webber, the turn to institutional politics lead to a de-radicalization of the MAS' political agenda, and eventually led to them making critical concessions with the elite lowland class and reformist middle classes when the Asamblea Constituyente entered into the formal legal production and approval process. And so, although the MAS made explicit linkages to "social movements" and indigenous organizations, these conversations were held within the liberal state institution. On the one hand, this enabled

Bolivia: Class Struggle, Indigenous Liberation and the Politics of Evo Morales (Chicago: Haymarket Books, 2011).

${ }^{200}$ Diaz, Critica de la Teoria del Poder Constituyente: Los Limites del Proceso Constituyente Boliviano.

${ }^{201}$ In this book Diaz is reviving a Marxist critique of the possibilities of cultural and political reforms within the capitalist economic system. His analysis is particularly important due to the fact that it was written in 2007 , years before the present contradictions Bolivia is facing became "visible." 
the reproduction of various structures of political neo-colonial power, and on the other, served to bring some representatives (Webber argues a more privileged intellectual and middle class) into the state apparatus. This prevented power being filtered upwards. And so, when the Asamblea Constituyente was approved by the MAS in 2006 these, and some more radical and popular demands were modified in that final state revision process. ${ }^{202}$

The Pacto de Unidad came to form during the Carlos Mesa years from the context of the mass popular mobilizations of 2000 and 2003 with the objective of collaborating on the production of the Constituent Assembly. Beyond the Constituent Assembly, this process became a space, which collided and coalesced with the working and popular sectors to articulate the demands that had emerged from struggles that were both immediate and historical. Moises Torres, an original member of the Pacto de Unidad argues that the Pacto de Unidad in its initial stages provided a space in which indigenous, campesino and popular sectors could imagine the reconstruction of the Bolivian State. ${ }^{203}$ For Isabel Rodriguez member of the Pacto de Unidad and a participant in the Foro del Sur held in CEDIB Cochabamba 2005:

El Movimiento Campesino indígena vive una realidad, nosotros no producimos en papeles, nosotros hacemos producir la tierra. Esa es nuestra realidad ...Por esto el Pacto de Unidad es de todos, es del movimiento campesino, es del movimiento indigena, es del movimiento popular, es de todos los bolivianos quienes quieren transformar una situación de miseria de explotación y marginación. ${ }^{204}$

\footnotetext{
${ }^{202}$ Here I am specifically referring to land, and the large-landholding restrictions that were removed.

${ }^{203}$ Taken from Interview with Moises Torres, Vice-President MST-Tierras Altas. CBBA: Bolivia.

${ }^{204}$ This quote was taken from the document produced at the Foro del Sur debate on the Pacto de Unidad which was organized in part by CEDIB and included over 85 participants, some of whom were members of the Pacto de Unidad, members of indigenous/campesino organizations, and political analysis and activists. CEDIB, "Foro Del Sur," CEDIB (2005).
} 
The six member organizations, ${ }^{205}$ along with other participating groups came to form the periphery, which would inform the production of the Constituent Assembly, often referred to by those who participated in the process as the re-construction of Bolivia. [La Asamblea] “...decía con todos, para todos, de todos. Incluyendo no excluyendo, refundar el país de la antigua constitución que estaba, que estaba ya caducado, destrozar la casa vieja y empezar desde el cimiento entre todos."206

Today, the Pacto de Unidad has become a central point of reference when referring to the ways in which the popular classes of Bolivia, campesino and indigenous actively participate $^{207}$ to produce the Bolivia they collectively imagined. That Bolivia that they envisioned would be anti-colonial and anti-capitalist. ${ }^{208}$ And, based on our recent historical memory, the popular political power that emerged from the uprisings following the Gran Marcha Indigena de Tierras Bajas did have enough political and economic force to put into motion historical uprisings that would lead to the overthrow of the neoliberal governments at the beginning of the $21^{\text {st }}$ century.

${ }^{205}$ CONAMAQ, CIDOB, CSUTCB, Interculturales, Bartolina Sisas, MST were the original six member organizations who participated in the production of the Asamblea Constituyente, following its development the MST withdrew from the Pacto de Unidad based on the MAS' political decisions regarding land and latifundios which were revealed post-facto (Interview with Moises Torres, Vice-President MST-Tierras Altas and participant in production of the Constituent assembly).

${ }^{206}$ Moises Torres. Vice-President of MST-Tierras Altas, Bolivia.

${ }^{207}$ Chavez and Mokrani, Los Movimientos Sociales en la Asemblea Constituyente.

${ }^{208}$ At the Foro del Sur in 2005, members of the Pacto de Unidad explicitly expressed the importance of the nationalization of Bolivia's resources- and the importance of renewed political and judicial representation and participation by indigenous peoples. 
The Pacto de Unidad was understood as more than just a body of organizations. It was conceived as an arena where, through the construction of constitutional change alongside political direct action mobilizations, change could be obtained. For Garces:

Las organizaciones lo entendian [pacto de unidad] y lo entienden como un mecanismo válido para trascender el modelo del Estado liberal y monocultural con fundamento en el ciudadano individual; ello, mediante la constatación de que el modelo liberal es el que ha impuesto la cultura occidental y ha marginado y debilitado las culturas originarias y los sistemas políticos y jurídicos de los pueblos indígenas. ${ }^{209}$

In conceiving the Pacto de Unidad as a popularized pressure mechanism that was organized and had collective organizational power and backing, its member organizations were able to pressure governments to act on their demands. If the government didn't act, as in $2003,{ }^{210}$ it was removed from office. As time progressed though the Pacto de Unidad began to take on a more consultant as opposed to confrontational role. As a result, member organizations, like the MST began to distance themselves from the organizational body.

The participation of the Pacto de Unidad in matters of state policy is one of the major institutional restructuring projects that the MAS government took on upon their election in 2005. Evo Morales has, on numerous occasions since his inauguration as president noted the central importance of social movement participation for the proceso de cambio. ${ }^{211}$ But, referring to social movements, and referring to the MAS' political

\footnotetext{
209 Garces, "The Domestication of Indigenous Autonomies, " 4.

${ }^{210}$ I do not wish to attribute the uprisings of 2000 and 2003 solely to the Pacto de Unidad. It was only one of the ways in which organizations organized themselves. Other networks and communities were equally important.

211 Regalsky, "Political Processes and the Reconfiguration of the State in Bolivia," 8-9.
} 
support bases is something distinct. On the February 22, 2006, during his first month evaluation of the presidency Morales claimed:

... los movimientos sociales sí o sí tienen que ir en la Asamblea Constituyente... Tiene que haber la mayor participación de los movimientos sociales, del pueblo boliviano, de los territorios, tiene que haber legitimidad acompañada por la legalidad... con los movimientos sociales vamos a cumplir con nuestras tarea... con ese aliento permanente del pueblo boliviano, especialmente los movimientos sociales dispuestos a apostar. ${ }^{212}$

Recent political MAS documents also reveal the centrality of popular participation through direct government-civil society interaction. For example, in the Nuevo Plan Economico de Desarollo Nacional, the Bolivian state is recognized as:

...potencia transformadora del cambio y su carácter esencial se expresa en un nuevo poder que surge de los sectores populares y de los pueblos indígenas, de las comunidades campesinas y de los trabajadores del campo y la ciudad. Este Estado representa el nuevo bloque de poder que enuncia los intereses de los que fueron marginados y excluidos durante siglos. Este nuevo Estado corresponde a una sociedad diversa, participativa y justa, basada en la solidaridad, cooperación y reciprocidad como rasgos distintivos de su propia identidad. ${ }^{213}$

The core of the power of the government is identified as lying within the process of the decolonization of power relations- the equal participation of popular sectors in matters of government. Some concrete examples of the ways in which the popular sectors of Bolivia participate in "Politics is through the annual Cumbre Nacional where various members of civil society come together to discuss which themes will be on the national economic and political agenda for the following year, ${ }^{214}$ Another channel that was opened with the Morales administration is through the creation of the vice-ministerio de los movimientos

\footnotetext{
212 Ibid, 8

213 Nuevo Plan de Desarollo del Estado, 38.

${ }^{214}$ What is interesting about this year's Cumbre Nacional is that the sectors that mobilized during the TIPNIS conflict withdrew their participation in the Cumbre that took place at the end of December. CONAMAQ, CIDOB and some sectors within the central worker's union (COB) opted not to participate.
} 
sociales. This is an institutionalized body that directly works with social movements, the idea being to propel political power upwards by bringing any concerns forward. For Tapia, there is a problem with making the conclusion that proximity with social movements within the liberal state apparatus necessarily makes the MAS the government of social movements, or the government of the people.

Durante un tiempo, al principio de su gobierno, Evo Morales mantuvo reuniones diarias- bien temprano al día- con los diferentes movimientos sociales y reuniones de evaluación del gabinete sobre todo con aquellas organizaciones de la sociedad civil aliadas. Hay un vinculo mas continuo antes, sobre todo entre Evo Morales y estas organizaciones de la sociedad civil, pero eso no equivale a un gobierno de los movimientos sociales. ${ }^{215}$

This question of the nature of the relationship between "the people" and "government" or the "people" and the "state" is one that is constantly re-emerging within the Left. A current debate between Jeff Webber and Federico Fuentes attempts to define what the MAS government is for the revolutionary Left. Webber argues that Evo Morales and the MAS are reformists, who are now incapable of revolutionary change since their assumption of political power, ${ }^{216}$ Whereas Fuentes offers up the common Garcia Linea catch phrase of revolutionary process, providing more excuses to the current risky political decisions of the MAS more than anything. ${ }^{217}$ I would argue instead that it is clear the terrain of struggle in the Gramscian sense has been historically altered, for better or worse, with the election of the MAS in 2005. There are however, significant concerns that need to be considered with the changing of the political terrain of struggle in Bolivia. To be clearer: What are the potential problems that can emerge with the

\footnotetext{
215 Tapia, La covuntura de la autonomia relativa, 143.

${ }^{216}$ Webber, "Revolution against "progress".

${ }^{217}$ Frederico Fuentes, "Government, social movements, and revolution in Bolivia today: A response to Jeffery Webber," International Socialist Review 76:March-April (2011).
} 
institutionalization, or the entrance, of civil society organizations into the fabric of the state apparatus? What are the possibilities for revolutionary transformation when preexisting state structures fail to be dismantled? Furthermore, to what extent can the state be mobilized in a counter-hegemonic project?

The Pacto de Unidad prior to the election of the MAS assessed some of these risks when organizations were debating whether or not a formal relationship should be expressed with the emerging Movimiento al Socialismo. In 2005, CEDIB held a "Foro del Sur" debate on the Pacto de Unidad and its position on the MAS' assent. In the minutes released from this event, it was confirmed that "En el Pacto de Unidad existe una plena conciencia de la necesidad de unir a todas las organizaciones indigenas y campesinas, al margen de las posiciones políticas particulares, con el único horizonte de impulsar las reivindicaciones históricas y estratégicas de sus sectores". At this particular forum participants argued that even though the MAS showed clear political possibilities as a political instrument, and that the very emergence of the Pacto de Unidad and the growing unity within the popular classes was organic and popular, plus despite the growing support for compañero Evo Morales, they would maintain their autonomy. While these concerns were voiced very early on, they continue to be of central importance when discussing the breadth of participation in Bolivia.

Following the past few years of political mobilizations and support of the MAS administration it is somewhat unclear as to who forms the MAS popular support base and who is amoung the elite that continue to support their policies. What is slightly clearer is 
who emerges in moments of what appear to be political crisis to defend the MAS and the proceso de cambio. From my fieldwork, I saw continued appearances (in large numbers) of the campesino organizations Bartolina Sisa (CNMCIOB-BS) and Confederación Sindical Única de Trabajadores (CSUTCB), huge mobilizations from the cooperative mining federations, and significant and persistent mobilizations from the Cocaleros Campesino federations from the Cochabamba Valley, sectors who were central in the uprisingings of the 90 s and 2000s. During the production and approval of the law, and later with the TIPNIS conflict, those sectors were criticized for the clientalist relationship they hold with the government. The following section attempts to complicate and break down these claims, to better understand the relationship between these sectors and the government.

Since Bolivia presents us with an incredible case of persistent popular resistance against the state that dates back hundreds of years it gives an interesting case for analysis of what happens when the popular sectors, or at least some of them, are invited and encouraged to participate in politics. Beyond that, and more specific for this particular case, what happens in the event that when presented with an instance where controversy emerges, what are the possibilities for contestation and negotiation in the battle for counterhegemonic alternatives between the state and "civil society." 


\subsection{The LRPCA: Controversy and "Consent"}

Yo creo que el principal es recuperar el protagonismo de la sociedad civil, se ha convertido un proceso terriblemente... Participación de la sociedad civil, cada vez con mas responsabilidad, y eso esta en la constitución, 34 veces hablo la constitución de participación y de control... 14 veces de control social. ;No se cumple! no se cumple... Las decisiones cada vez son mas estatales, mas estatistas. mas de arriba. ${ }^{2 / 8}$

- Raphael Puente

As alluded to in the previous chapter, due to capitalist tendencies of the LRPCA and some concessions surrounding land made to the crucena elite, the rolling out of the MAS' new agricultural development plan has been met with increasing dissent. What emerged upon the release of the LRPCA, however, was not solely a critique of the MAS' decision to approve the law, or particular ministers in its development, but rather what emerged was fractioned resistance against particular elements of the law, plus also broader questions of the proceso de cambio. Within the questions that emerged, a resonating critique towards the Pacto de Unidad and the perceived co-optation of the campesino movement by the Morales administration surfaced. The critique caused increased fragmentations both within and between the subaltern and popular classes.

When the LRCPA was approved by the camara de senadores in June the popularized criticism was twofold. First, it was against the capitalist-nature of the law (as we saw in chapter II). Second, the blame was placed upon the member organizations of the Pacto de Unidad (cocaleros and campesinos) who had approved the law without generalized consent from their bases.

\footnotetext{
${ }^{218}$ From Interview with Rafael Puente.
} 
Later, the LRPCA was re-introduced to the member organizations of the Pacto de Unidad for signing approval post-revisions four out of the five member organizations at that time approved the law without revisions. Only CONAMAQ voiced their disapproval of the law, refusing to sign their approval. It appeared to Rafael Quispe, the then president of CONAMAQ that the law had been changed without their participation- leaving him to refuse to sign it;

...entonces regreso y ya estaban[articulos sobre transgenicos]; Era difícil sacarles, ¿no? Entonces el CONAMAQ, no soy solo, somos varias autoridades donde hemos reclamado, no hemos firmado ¿no? Pero, sin embargo las otras cuatro organizaciones han estado de acuerdo y lo que hicieron, es mas aprobar ¿no? Aprobar, aprobar... ${ }^{219}$

Whereas the Bartolinas, CSUTCB and Interculturales took to proceeding with "business as usual," other organizations like the CONAMAQ, MST and AOPEB took to informing their bases to come to a consensual decision process regarding how to deal with the law. CONAMAQ and the MST held their own information sessions where the authorities of their communities were invited. They came to participate and learn about the law, and the issue of transgenic seeds. At both of these meetings, it became apparent that the hostility was also directly targeted at their brothers of the Pacto de Unidad who had approved a law permitting transgenic seeds. Similarly when discussing transgenic seeds with members of both the Bartolinas and the CSUTCB it appeared as though their knowledge of GMO's was limited. Dona Martinez Colque, a Bartolina and aged participant in popular struggles argued "no nos vamos a permitir esto" 220 when questioned

\footnotetext{
${ }^{219}$ From an interview with Rafael Quispe.

${ }^{220}$ From interview with Dona Martinez Colque.
} 
about the legalization of transgenic seeds in the LRPCA, despite the fact that the Bartolinas had approved the law. Licarion Soto, a member of CSUTC.B argued that transgenic seeds are already in the country and so, "a partir de esta ley ya no entramos no se podrían introducir pero si introducen algún producto transgénico tiene que llevar el sello que diga como el cigarro el cigarro mata entonces este es un producto transgénico entonces el consumidor dirá pues consume o no consumo,"”21 leaving the onus up to the consumer. Further, based on the historical anti-transgenic mobilizations that were propelled by the CSUTCB and Bartolinas, why is it that these organizations suddenly had a turn-of-face?

It is a commonly expressed criticism of the new institutionalization of civil society, that leaders of these organizations have been "co-opted" or purchased with items and prestige by the MAS. Lic. Gonzalo Vargas Rivas:

Lo que ha pasado, es que en la ley, esta en la ley, hace poco promulgada, el movimiento campesino tiene harto peso político ¿no?, y sobre todo su dirigencias. Una cosa es cuando hablas con el dirigente, y otra cosa es cuando hablas (K: con sus bases) con la base, ¿no cierto? El dirigente ya esta mas arraigado justamente por su intermediación entre su comunidad y el mundo político institucional, esta digamos, sus elementos de interés personal han aflorado mas hacia una tendencia mas individual, ¿no? Que la gente de la comunidad, por tanto, no creo yo que refleje. Por eso cuando me dicen "han dicho los dirigentes", ah... es una cosa los dirigentes, pero habría que escuchar a sus bases. Entonces, yo me imagino que la ley, esto una opinión personal...creo que la ley de la revolución productiva comunitaria, tiene una fuerte carga de la opinión y los intereses de esta capa dirigencia, que en este momento, mas esta en una estrategia de copamiento de la institucionalidad estatal del mundo republicano liberal, antes que de su estrategia comunitario. ${ }^{222}$

\footnotetext{
22. From an interview with Licarion Soto of CSUTCB.

222 Interview with Lic. Gonzalo Vargas Rivas.
} 
Raphael Puente (ex-advisor to Evo Morales and current political commentator) argued that what has increasingly happened is counter to the MAS' rhetoric of participation; a concentration of power and decision-making upwards.

RP: Y ahí hay es un elemento muy agravante, y es que los dirigentes de las organizaciones sociales

KF: ¿Del Pacto? ¿los grandes?

RP: Claro, todos se dijeron, vamos a apoyar, vamos a estar de acuerdo, el pueblo apoya presidente; Sin consultar para nada la opinión de sus bases, en los hechos las bases estuvieron en desacuerdo... Evo tuvo que dar marcha atrás, y es que los dirigentes han dejado de ser representantes de sus bases, les han convertido en autoridades... por si mismas, con lo cual pierden todo vigencia pues. Ahora eso también tiene un origen preocupante ¿no? De verticalismo. Entonces la cosa el verticalismo llega al extremo. El verticalismo llega al extremo de que muchas veces a los dirigentes se los elige por recomendación de Evo...

Based on my conversations with the member organizations that still maintain alliances with the MAS (primarily the CSUTCB and Bartolinas) I noted this tension however wish to complicate it a bit further. Leaders have been co-opted with their exposure to the political and economic opportunities that come with having a solid working relationship with the MAS. In order to maintain good relations with the government they continue to support their projects, regardless of their substance and regardless if in practice they are what they fought to eliminate. There is another element; the importance of ideology, the ways in which the counter-hegemonic project that the MAS represents resonates with collective social memory of struggle, but also of the still persistent economic inequalities rampant across the country. Since there is this suspicion of leadership co-optation, as well as a concentration of power from above, this has resulted in a simultaneous demobilization and remobilization of the political conjuncture in Bolivia. When I refer to 
demobilization, I am referring specifically to the role the Pacto de Unidad has held institutionally, in terms of successively approving legislation at the behest of the bases which they represent. In the case of the LRCPA, they approved legislation that will further marginalize the very bases they represent; and did so in contrary to their past experiences of struggle and resistance.

With the verticalization of power, the bureaucratization of political participation and the co-oportatization of popular participation, other organizations as well as civil society are beginning to talk of "recuperation." It seems only natural that there would eventually be a re-mobilization of political participation among and within the subaltern and popular classes given the persistance of popular struggle historically. Despite this fact, the ways in which politics are being re-vitalized can provide us with the complexities and difficulties that emerge when constructing counter-hegemonic projects from below.

\section{3 ¡Esto es el pueblo, el pueblo no es pagado! $!^{223}$}

The LRPCA revealed a clear example of the emerging critiques against the campesino organizations of the Pacto de Unidad and their decision to support the MAS' decision to approve the law. Thus, when another controversial MAS project emerged, the highway San-Ignacio de Moxos- Villa Tunari, the Pacto de Unidad became the central focus where popular unification should emerge and contest the government's actions. When it

\footnotetext{
${ }^{223}$ This was taken from a chant that surfaced in a pro-TIPNIS mobilization following the contra-marcha by the MAS.
} 
did not, and became divided on the issue, the political event revealed a larger fractioning occurring within the popular classes.

In June 2011 , the MAS government announced that in collaboration with the Brasilian government and IIRSA, they would be constructing the highway San Ignacio de MoxosVilla Tunari (see Map III). This highway (yellow-black dashed line) was set to pass directly through the Territorio Indigena Parque Nacional Isiboro Sécure (TIPNIS) territory. The TIPNIS communities fall under the overarching representation of the CIDOB, and so, upon news of proposed construction, Adolfo Chavez of the CIDOB immediately announced the rejection of the project by TIPNIS. This rejection was made on the basis that it was an imperialist project of the Brasilian government, ${ }^{224}$ and that their communities had not been privvy to the "consulta previa" as outlined in the NCPE. ${ }^{225}$ This is significant because we can, after outlining the centrality of land and power in the previous chapters, see the ways in which the LRPCA and TIPNIS highway are not two separate events, rather the ways in which they are connected and grounded in the political and economic power of land.

\footnotetext{
${ }^{224}$ In an interview between Fundacion Tierra and Adolfo Chavez which I observed on July $24^{\text {th }}$, Adolfo Chavez was very clearly identifying the project as a tool of the expansion of the Brazilian empire. Later on in the conflict, however, his discourse shifted. See Francescone, "Internal Fractions and the Right." ${ }^{225}$ See: Kirsten Francescone. "Marching for Land, Dignity and the Proceso de Cambio." The Bullet, 540 (2011).
} 


\section{Map III: TIPNIS Territory and projected highway project}

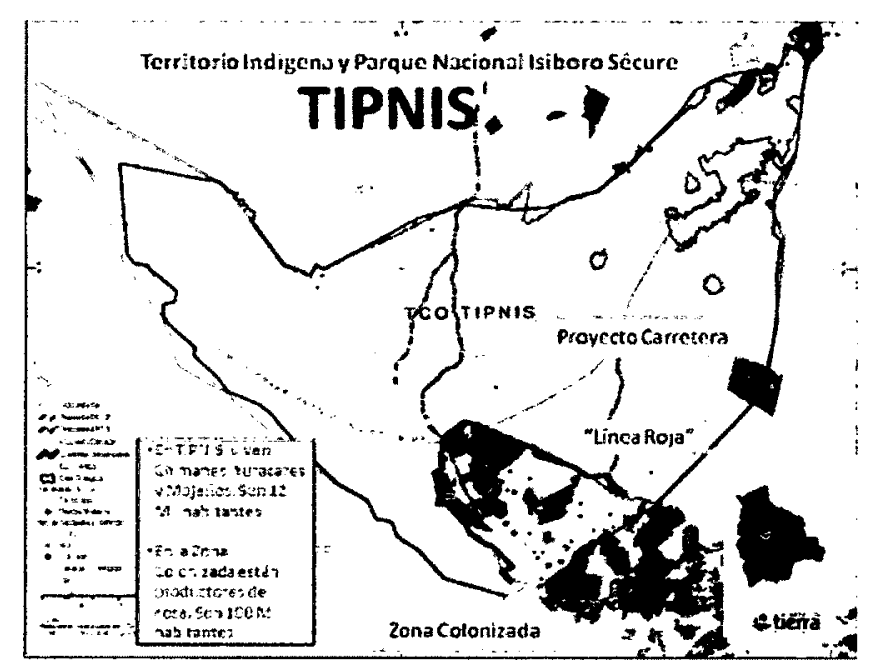

Source: Fundacion Tierra

CONAMAQ also saw the linkages between their fight against genetically modified organisms and their lack of consultation during the LRPCA, and what was going to be happening to their "hermanos de tierras bajas." On the 29th of July CONAMAQ signed and presented a letter of support to their lowland indigenous brothers of the TIPNIS and CIDOB. CONAMAQ expressed their decision to march on August 15th against the construction of the highway San-Ignacio de Moxos- Villa Tunari with the TIPNIS and CIDOB against the project, and against genetically modified seeds.

The last week of July, I attended a 3-day general assembly for CONAMAQ authorities, organized around the Consulta Previa. The opening remarks of Day I presented the 
concerns of CONAMAQ as those concerns that were beginning to emerge popularly,

particularly within indigenous communities:

...hemos visto que para esas dos sociedades el enemigo son las transnacionales y todas estas polémicas leyes que se van implementando es favorable que anteceden a las transnacionales ahora... no hay permitir que maten a nuestra madre tierra y a lo que es la vida misma no podemos permitir. entonces lo que yo he empezado a proponer en principio es sacar un a resolución fuerte y contundente siguiente conclusión que van es conformar una condición un tanto un consejo no se donde lo pondría a la cabeza del CONAMAQ. El objetivo para mi es luchar contra el sistema que ha generado el capitalista que supuestamente cambiando al presidente ya habíamos vencido, no. El sistema del capitalismo boliviano esta sigue vigente en Bolivia con dominio de las transnacionales lo que no pudo ser Goni, Tuto, etcéteras. Un presidente que salía de las bases lo esta logrando, continua la lucha creemos que queremos tomar esa estrategia de incidencia... ${ }^{226}$

Day One's seminar was an information conference surrounding the LRPC.A. This included participation from various indigenous communities. There was participation from other NGO research institutions and civil society organizations including the MST, urban movement "La Ultima Trinchera", and representatives from the network of institutions against the LRPCA in Cochabamba. This full-day seminar provided presentations from various people and organizations, as well as the collaborative production of a collective statement against the new LRPCA, which specifically but not exclusively focused on transgenic seeds. It is important to note that during this seminar discussions began regarding the rapidly emerging TIPNIS conflict- with La Ultima Trinchera $^{227}$ explicitly requesting for support from CONAMAQ for their lowland TIPNIS

\footnotetext{
${ }^{226}$ Leader of CONAMAQ and Vigil participant, July 24, 2011.

227 La ultima trinchera was an urban, primarily university student led, network that had developed out of the emergence of the MAS' latest political decisions. According to Violeta Tamayo one of the selfproclaimed leaders, the group (previously MAS supporters and most fighters in the Gas Wars) was concerned about the recent political decisions of the MAS surrounding transgenic seeds, and the SanIgnacio de Moxos highway project. They had formed the coalition amoung various urban movements in order to hold public forums and develop a counter discourse surrounding the possibilities for transnational control that the LRPCA and the TIPNIS conflict were revealing.
} 
brothers, thoughts which were echoed by President Raphael Quispe when making

concluding remarks of Day I of the seminar:

...por que esta relación de la consulta y transgénicos no, ya este se esta saliendo del camino. Ya no sabe de transgénicos, madre tierra, y consultas. No cobrando un la consulta es un mecanismo, una puerta para otro derecho de los pueblos indigenas verdad la libre determinación de autonomía del gobierno y con esto ya nos han... la consulta debería ser para esto decimos nosotros. Vamos a hacer estas cosas y lo otro hacemos la consulta es para el TIPNIS un tema relacionado; madre tierra, TIPNIS, productos transgénicos. ${ }^{228}$

The following two days were designed to develop and present a law to the cámara de los diputados called the Anteproyecto de la ley de la Consulta Previa and the means for indigenous communities to recover their constitutional rights to be consulted prior to any mega-projects in their communities. ${ }^{229}$ Towards the end of this two-day assembly, it became clear that the TIPNIS conflict was gaining momentum in the context of the "consulta previa". On the final day the floor was open to the authorities debating whether or not CONAMAQ as an organization should support the CIDOB and TIPNIS and march with them in August. ${ }^{230}$ Later that week the authorities decided to support the march, and officially released their statement to the press and to the CIDOB on July $29^{\text {th }}$.

\footnotetext{
${ }^{228}$ From recordings of the Cumbre contra los transgenicos, CONAMAQ, $24^{\text {th }}$ of July, La Paz.

${ }^{229}$ From the Anti-proyecto de la ley de la Consulta Previa. Presented to Camara de los Diputados, July 29.

${ }^{230}$ Although at these meetings no official position was made to support or not support the highway, it was clear that the room was divided on the issue.
} 


\subsection{The XIII March for Territory and Dignity}

There undoubtedly exists a tendency to unification in the historical activity of these [subaltern social] groups, but this tendency is continually interrupted by the activity of the ruling groups... ${ }^{231}$ Antonio Gramsci

On August 15th, the CIDOB, CONAMAQ and TIPNIS departed from Trinidad, Beni on the XIII Marcha Indigena de Tierra y Dignidad. ${ }^{232}$ While the two "indigenous" organizations openly expressed their support for the TIPNIS and their rejection of the MAS' political tendencies of the present, the "campesino" organizations, the CSUTCB, Bartolinas and the Interculturales refused to express their solidarity with their brother organizations against the MAS. The TIPNIS conflict began to take form as yet another example of the political maneuverings of the MAS, and the support or rejection of the highway became one's support for or against the MAS government. This was facilitated and maintained by the statements that emerged daily from MAS deputies and ministers, and also through the discourses of the leaders of the other campesino organizations. Instead of focusing on the problematic of the political move by the MAS, the Bartolinas and CSUTCB leaders took this as an attack on the MAS, and an attack on the proceso de cambio that they were trying to collectively construct.

\footnotetext{
${ }^{231}$ Gramsci, Selections from the Prison notebooks, 55.

${ }^{232}$ For the purposes of this section I will not be going into details on the conflict, I am writing on the conflict elsewhere, what is significant for this section is the ways in which the Pacto de Unidad and what was happening within and beyond it can be seen as a window to the larger emerging tensions within the popular classes who are negotiating and contesting the proceso de cambio and the MAS.
} 
The march persevered throughout August and September while the government launched an anti-TIPNIS, anti-NGO campaign claiming that those who were marching had been manipulated and were being used to further American interests in the country. This not only served to obfuscate the political and economic interests at stake for regional and transnational capital, but also resonated within Bolivia's neocolonial history with the DEA and NGO presence following the New Economic Plan of 1985. This period in particular, as seen previously, contributed to the aligning of popular-national and decolonial agendas of the subaltern and popular class mobilizations. The MAS government was able to manage and manipulate, first by arguing that the indigenous communities had been influenced by NGOs with foreign interests, and later by arguing that the Right wing had penetrated into the communities and was using this as a political opportunity to advance their own agenda. ${ }^{233}$

On September $6^{\text {th }}$ it was announced that colonizadores had set up a counter-blockade in Yucumo and were demanding the construction of the highway- arguing their brothers needed to dialogue with the government. Later that afternoon, while conversing with an authority from CSUTCB, it became clear that beyond ideological support, the CSUTCB was sending resources to this blockade: "ellos están diciendo que no quieren la carretera, que no quieren desarrollarse pero están marchando y sacando la madera en el mismo

\footnotetext{
${ }^{233}$ The right-wing did penetrate into the leadership of the CIDOB which ultimately manifested itself in the alternative cumbre held in December between $\mathrm{CIDOB}$ and the right-wing opposition and the formation of the bancada indigena. This is something we are working on elsewhere, for the purposes of this paper, however, it is important to note that those in opposition were not a homogenous group of right-wing opposition, rather the majority of people who began and stuck with the TIPNIS were from urban, popular, working, indigenous and campesino sectors- all taking on the capitalist political tendencies of the MAS through the TIPNIS conflict.
} 
tiempo, no se puede hacer esto." As he was telling me this, his phone rang, and after talking a few minutes with someone who appeared to be heading towards the counterblockade, he shrugged to me and said "nosotros, no nos vamos a permitir esto." A few days later, the president of the CSUTCB Robert Coraite, in a press conference denouncing the march referred to those marching as "salvajes." The assembly of the blockade in Yucumo revealed the clear tensions that were emerging within the popular classes. Tensions founded in pre-existing racial and regional tensions, which despite historical indigenous alliances between tierras altas and tierras bajas, were driving a wedge between indigenous and campesino populations. ${ }^{234}$

The Yucumo blockade, along with police checkpoints sent by the MAS, resulted in preventing the passage of food and water coming from the surrounding cities to the march, thus inflicting a form of violence- the colonizadores through the blocking of the passage and the police through their inaction. ${ }^{235}$ The colonizadores were also armed when the counter-blockade left to meet the march and provoke confrontation on September $20^{\text {th }}$. The inaction by police to intervene in that march and prevent the possibility of conflict spoke clearly of the alliances between the state and the campesino popular classes. It also spoke to the ways in which this conflict had served to polarize and militarize campesinos against indigenous communities as protectors of the proceso de cambio.

\footnotetext{
${ }^{234}$ Francescone, "Internal Fractions and the Right."

${ }^{235}$ Ibid.
} 
With the militarization of the counter-blockade in Yucumo, and the increased tension between the CIDOB-CONAMAQ and CSUTCB-Bartolina-Interculturales alliances, we began to experience tensions emerging and erupting in the support-vigil San Francisco. ${ }^{236}$ As one indigenous leader who was living in the vigil told me, "estamos luchando contra nuestros hermanos, ellos no son nuestros enemigos, son gente con quien hemos luchado." When the "contra marcha" arrived into La Paz on October 12th, one week before the arrival of the TIPNIS march, the atmosphere of the vigil was extremely tense. Rumours had been circulating that there would be confrontation, that the march would attack the vigil, and they were going to have their "meeting" in Plaza San Francisco. When it arrived however, the countermarch, consisting of Cocaleros and Campesinos, Bartolinas, Kataris, cooperativistas and public officials was anything but violent:

Fui en camino hasta la cola de la marcha cooperachos ${ }^{237}$....cooperachos ...cooperachos...Estábamos contando, hemos llegado hasta 9000 cooperativistas al final. Luego las Bartolinas, pero eran pocos....Cocaleros de Cochabamba... sindicatos campesinos.... mas cocaleros, oficiales publicas....no hemos podido llegar hasta la cola. Han marchado casi todo el día, un mar de gente al frente de la vigilia desde las 1030 hasta las 1430 pero no hubo enfrentamientos, sino adentro de la gente de la clase media que estaban por el lado de la avenida gritando a los marchistas... ${ }^{238}$

In fact, the demands of the countermarch were extremely similar to those of the vigil; get rid of the right-wing opportunists, get rid of the corrupt ministers, and recuperate the proceso de cambio. Therefore, even though the highway became the point of contention, on a much larger scale, the vigil and the members of the Pacto de Unidad were revealing

\footnotetext{
${ }^{236}$ I moved into the Vigilia San Francisco on September $24^{\text {th }}$, which formed in solidarity with the XIII Marcha by the women leaders of CONAMAQ in la Paz on September $19^{\text {th }} 2011$.

${ }^{237}$ Common way of referring to cooperativistas, miners who work in cooperative mines.

${ }^{238}$ From fieldnotes: October 12, 2011
} 
their very nature as those same organizations that fought to expel Sanchez de Lozado from the country in 2003 and eventually lead to the MAS' election in 2005. The popular classes- some indigenous, some campesinos, some workers all claiming the importance of "la recuperación del proceso de cambio", centered around and grounded in land.

Throughout the conflict the Pacto de Unidad served two main purposes. The first was that it served as a body whose campesino membership undoubtedly supported the MAS government and Evo as president, at least at the authority level. ${ }^{239}$ In this sense, it demobilized its own bases to follow line and support the MAS government no matter the policy, the action or the tendencies. At one point before the large TIPNIS arrival in La Paz, a leader of a campesino community from northern La Paz talking to me expressed his discomfort with the position of the CSUTCB saying how his community was planning on marching with the TIPNIS in order to recuperate the proceso de cambio. He expressed his concern for marching and being considered a traitor but claimed that the government had gone too far. ${ }^{240}$ This was also reflected in the ways in which presidents of both the Bartolinas and the CSUTCB echoed Evo's arguments of the marchers being 'opportunists' being managed by the Right-wing interests of the country. The ways in which popular organizing and mobilizing has been slowed or severely debilitated by its institutionalization is also reflected in a interview I had with Oscar Olivera, a key leader in the Coordinadora of the Guerra de Agua in 2000,

\footnotetext{
239 There are several instances when specific campesino locals announced publically that they were not supporting the official position of their unions. And on September 27, a campesino union authority from a CSUTCB local in the department of $\mathrm{La}$ Paz approached the vigil requesting permission to march with CONAMAQ and CIDOB. He explained to me later that he was nervous about their local's participation in the mobilizations because of potential backlash from the CSUTCB but also from the indigenous communities with whom they would be marching. From fieldnotes, September 27, 2011.

${ }^{240}$ From fieldnotes, October $10^{\mathrm{d}}, 2011$, La Paz.
} 
OO:...el Pacto de Unidad tenía muy claro muchos aspectos de la política en el tema indígena, en el tema territorial y eso definitivamente no esta ipues! coincidiendo con las políticas gubernamentales, a las cuales han subordinado muchos dirigentes del Pacto de Unidad. $Y$ creo que ha ido mantenido, yo digo algunos sectores como el CONAMAQ por ejemplo, ¿no? y la CIDOB por ahí. Pero, yo creo que mas que un análisis del Pacto como tal yo creo que ha habido un proceso de desfragmentación, de descomposición, de desconfianza, división, producto yo diría... des absoluta subordinación en base a prebendas, de los dirigentes al gobierno y una política gubernamental también de cortar a estos dirigentes para..

$\mathrm{KF}: ¿$ desmovilizarlos?

OO: Desmovilizar los movimientos sociales, ¿no $?^{241}$

When the march descended on the vigil, and people began to see the sheer volume of marchers, primarily women of pollera and cooperative miners, it was a devastating moment. Immediately people began saying that they had all been paid to march, that Evo had sent buses to bring entire communities into La Paz to show the highway and the MAS still had support. In part, this is true. Later that afternoon the national news channels were claiming that the public officials who had previously received their 1000Bs bonus were told that one of the conditions of this bonus was to fund their expenses to march. Further, the cooperativistas, who were marching in full force, had just negotiated deals ${ }^{242}$ with the MAS government regarding their work and contracts the day before. The contra marcha provided a window into which we could begin to see the sheer complexity of the political conjuncture at hand; the power of the hegemonic consensus among the subaltern and popular classes which equated the proceso de cambio, not as

\footnotetext{
${ }^{241}$ From interview. Oscar Olivera.

242 The deals I am referring to are the two decrees that were passed by the government in favour of cooperative production, the central bank would buy gold from cooperatives in La Paz, and cooperativistas would be exempted from paying an internal tax on their production.
} 
situated from within, but something that was contingent on the survival of the MAS government.

\subsection{Political consciousness and the constraints of hegemony}

The war of position demands enormous sacrifices by infinite masses of people. So, an unprecedented concentration of hegemony is necessary and hence a more interventionist government which will take the offensive more openly against the oppositionists and organize permanently the "impossibility" of internal disintegration... ${ }^{2+3}$ -Antonio Gramsci

La revolución no se derrumbo de un solo golpe: cavo poco a poco, pedazo a pedazo. La contrarrevolución no paso sobre el país como una planeadora y sus efectos fueron demoledores, necesito varios anos para echar abajo lo que encontraba a su paso ${ }^{244}$

-Sergio Almaraz

It appears that MAS popular support is slowly disintegrating. The series of controversial law developments throughout my fieldwork, culminating with the TIPNIS conflict have resulted in increased criticism from within, not only among "indigenous" organizations but also within the popular and working classes. This culminated on December $21^{\text {st }}$ when CONAMAQ announced that they would be de-ratifying from the Pacto de Unidad in order to distance themselves with the MAS government, arguing that the MAS is not heading the proceso de cambio. This is significant in that it represents a fracture or rupture in the political conjuncture in Bolivia at this time. For the country's "first indigenous government", it is difficult to see the ways in which hegemony has been

\footnotetext{
${ }^{243}$ Gramsci, Selections from the Prison Notebooks, 239.

244 Almaraz, Obras Completas, 455.
} 
maintained among such organizations that identify as indigenous when CONAMAQ and the CIDOB have made public moves to remove themselves from the MAS and Pacto de Unidad.

It is extremely important to remember the sheer volume of political weight and power that propelled the Morales administration into power in 2005 , and its roots in the subaltern and popular classes of Bolivia. It is common Evo-centrism to attribute the advances that have developed in Bolivia to the MAS administration, but we cannot forget that it was the sheer and undivided resistance of his support bases that elected the MAS. Evo has become a symbol of hope, continuing to maintain that hegemonic presence as president in maintaining a discourse that is anti-neoliberal and anti-colonial, at home and to the international arena. Further, as Webber reminds us, he emerged from a popularized resistance, a cocalero from the Chapare, indigenous and militant. He climbed his way up the ranks, which meant that he held a central antagonistic and early on radical presence in the past political upheavals.

Politics is expansive and deeply seeded in the history of collective social memory of Bolivians, and since, as we have already seen, the construction of a new 'better way of living' has continued to garner speed and support in the recent years. The unrelenting resistance to the sheer political, economic and cultural violence that Bolivians, especially poor indigenous Bolivians faced during the last years of neoliberal governments is clearly marked in the memory of all of those with whom I worked and collaborated with. That is what complicates the strength of hegemony and unrelenting support for the MAS. People 
constantly informed me that they fought, and lost some companeros to the political repression in the 1990's and 2000's- this was a constant reminder of how things were, and how things could be again, very quickly. This complicates the simplicity of saying that all masistas are co-opted, have been purchased, or are ignorant. It does not mean that those are not also realities, rather that the issue cannot be removed from its historical context. And just like the popular uprisings which brought Evo into power in 2005 arose from the culmination of years of historical political repression and resistance, so too will continue the construction of a counter-hegemonic project.

Today, the MAS government clearly is struggling to maintain hegemony that unifies the national-popular and de-colonialists, resulting in the ebbing and flowing of popular eruptions but also evident in the intra-class struggles that have continued to emerge and take on a racialized presence. This stems from the increasingly visible "cracks" in the political conjuncture which at times have revealed the discontent between the "cultural" and the "economic and political" changes that have been occurring, Gramsci asks "can there be cultural reform and can the position of the depressed strata of society be improved culturally without a previous economic reform and change in their position to social and economic fields?"245 To which he responds no, there cannot, hegemony can only maintain the illusion for so long, before consent is ruptured. In the event that hegemony is ruptured, and the dominant social group has exhausted its consent-garnering function, "the ideological bloc tends to crumble away; then 'spontaneity' may be

\footnotetext{
${ }^{245}$ Gramsci, Selections from the Prison Notebooks, 133.
} 
replaced by 'constraint' in ever less disguised and indirect forms, ${ }^{276}$ aka: coercion. Since the strength of the survival of the dominant class is measured by its ability to maintain hegemony, we have seen the MAS begin to exercise "constraint in ever less disguised and indirect forms" through the repression of the TIPNIS march in September 2012. The movement towards coercion in and of itself implies the weakening of its hegemonic hold over its bases. One has to question how much longer the ideological stronghold of the MAS can be maintained within its popular masses.

Such mobilizations, as well as the continued revival of conflict reveal some key tensions that are emerging in terms of where Bolivia will go from here. Despite some significant changes in the cultural terrains, the centrality for both conflict and change lies in the relationship that campesinos, indigenous communities, and the popular classes have to the land and resources. This relationship regardless of the rhetoric coming from the MAS has yet to be revolutionized. In spite of advancements made in the NCPE surrounding the rights of indigenous people to be consulted over territorial resource claims, time and time again, when fronted with the interests of capital, these "constitutional rights" go unnoticed. ${ }^{247}$ The final chapter will explore the ways in which, the national-popular and indigenous alliances are continuing to emerge and strengthen to re-ignite popular mobilizations that have been slowly erased from the political landscape. Whereas we have observed a turn to a demobilization of institutional politics, we are presently witnessing the re-emergence of popular dissent, protest and construction.

\footnotetext{
${ }^{246}$ Ibid.

${ }^{247}$ Villegas, "Puede haber Consulta Previa?"
} 


\section{Chapter 5: Strategic Alliances and a Politics of Possibility}

Ya está decidió vamos a marchar con los hermanos del TIPNIS por el respeto a nuestros derechos, por la consulta, por nuestras tierras y territorios ${ }^{248}$

Various attempts were made at bridging and expanding alliances for the re-mobilization of the popularized politics as the two conflicts unfolded. The following chapter will identify the successes and failures of these alliances, and the ways in which they have contributed to an opening of the possibilities for a more sustained mobilization in the years to come. In the following chapter I will primarily focus on the TIPNIS mobilization and the LRPCA will fall into the backdrop. Although the law became lost in the political upheaval that emerged with the TIPNIS conflict, the foregrounding of the alliances that emerged between highland and lowland indigenous organizations came from the catalyzation of the LRPCA in July.

The TIPNIS conflict erupted over indigenous communities opting to protect their land, with Justa Cabrera, indigenous leader for the TIPNIS, aptly summing "hay dos cosas que nunca he tenido, plata ni miedo. Si tengo que marchar hasta la muerta para proteger mi territorio, lo haría con gusto."249 With the government's continued inability or unwillingness to protect and preserve land and environment in the face of capital investment and extraction, the mounting tensions led to the political conjuncture, the TIPNIS conflict, whose conclusion has yet to be resolved.

\footnotetext{
${ }^{248}$ El Opinion, "Conamaq inicia preparativos para la marcha en defensa del TIPNIS", El Opinion, August 1st, 2011. This quote is from Tata Walberto Baraona Garnica, Mallku del Medio Ambiente, CONAMAQ. ${ }^{249}$ From a television press interview she gave in September, prior to the police repression.
} 
Upon deciding that CONAMAQ, the indigenous highland organization would march in solidarity with the CIDOB at the anti-GMOs general leadership meetings in July, there rose an important alliance between highland and lowland indigenous groups against the TIPNIS project and GMO seeds. On July $29^{\text {th }}$ CONAMAQ announced their participation in La Gran Movilisacion en Defensa de la Consulta Previa Vinculante de la Madre Tierra with their official press release stating "las naciones originarias de tierras altas y bajas...nos llama a la UNIDAD para defender el derecho a la consulta previa libre vinculante, la madre tierra, y en contra de los trangenícos." ${ }^{250}$ With CONAMAQ, CIDOB and other smaller regional indigenous organizations, and individuals marching in solidarity with the TIPNIS, the government began to take action to stall, quell, and demobilize the growing civil society support that was rapidly increasing.

The MAS government launched a propaganda campaign in favour of the San-Ignacio de Moxos- Villa Tunari highway and simultaneously launched an anti-indigenous campaign in the process. These two campaigns became increasingly colonial and racist as time went on, with a final television commercial claiming "asi vive los TIPNIS" a sepia commercial showing naked children with bloated bellies, suffering in poverty which was aired on both public and private stations for over two weeks. The government was arguing towards the end of the campaign that the TIPNIS did not know what was best for them, that these communities were living in poverty, and as such the government was going to make the decision for them, with this being in their best interest. The commercial was

\footnotetext{
${ }^{250}$ Declaracion de UNIDAD del CONAMAQ, the 29th of July, 2011.
} 
reminiscent of something you would see for Western viewers from an organization such as World Vision and not something that would emerge under the "first indigenous government" of the Plurinational State of Bolivia. It became common that when talking about the highway and the government's unwillingness to even dialogue that, si o si, la carretera pasará por los TIPNIS.

Aside from propaganda campaigns, the government also took to practical ways of stalling the march, including sending out two or three ministers at a time into the march to give the indigenous marchers their "consulta previa." When leaders like Adolfo Chavez and Raphael Quispe expressed that the pre-consultation process could not take place during the march since the contract had already been signed, they claimed they would negotiate only with the president (nuestro hermano Evo Morales) and only upon their arrival in La Paz. The government, however, argued that the marchers were being unreasonable. On several accounts Vice President Garcia Linera appeared in national press conferences claiming that the government was doing everything in their power to meet with the indigenous communities. And so this process of ministers arriving to the march, artificial meetings, and then ensuing slander campaigns continued to stall the march, slowing it down and making its anticipated arrival date the longest in the history of this march.

To further solidify CONAMAQ's and highland indigenous support of the march, and to support their "hermanos de tierras bajas," the women leaders of CONAMAQ made the decision to set-up a vigil in La Paz. When it was revealed that the government had gone so far as to stop and stall the entry of food and support to the march, the women took 
matters into their own hands. On the September 16th, over a month after the march set off from Trinidad the women authorities set up camp, consisting of a tarp-tent approximately $20 \times 10$ feet in size and moved in with the CIDOB in protest of the highway. ${ }^{251}$

The C.IDOB-CONAMAQ-TIPNIS alliance did not falter despite attempts to create divisions to delegitimize their cause. In fact, it appeared as time went on, the MAS' inability to truly engage in a free and informed pre-consultation process was revealing their intentions behind the highway, ${ }^{252}$ which weakened their ability to maintain consent within the popular, urban and intellectual classes. The vigil became the most important physical and symbolic space throughout the escalation of the political mobilizations that took place nationally in the weeks following the police repression for and against the TIPNIS conflict, and its impact on mobilization of the paceno population cannot be understated.

For Toribia Lero, technical support of CONAMAQ ayllus de Cochabamba, "Nuestra vigilia en San Francisco sigue siendo el punto de información al pueblo, el punto de recibir el apoyo del pueblo, sigue siendo el punto de unión de los indígenas con el resto del pueblo boliviano."253 The vigil, served as a uniting point within the popular and

\footnotetext{
${ }^{251}$ I received word from one of my contacts in CONAMAQ that they would be moving into the plaza in front of San Francisco. Since at the time I was in La Paz attending the LRPCA commissions and running some formal interviews, I decided to head over to the plaza to spend a few nights with the some of the women whom I had previously worked with. I went to visit the vigil on Friday September $23^{\text {rd }}$ and requested that I camp out for the weekend with the women authorities, and after some hesitation from a few of the women I did not know, it was agreed that I could stay.

${ }^{252}$ Various ministers and the president and vice-president were quoted saying yes or yes the highway will be constructed, with or without the consent of the communities within the park.

${ }^{253}$ CEDIB, "Entrevista: Las vigilias por el TIPNIS. "Las mujeres no podiamos permitir eso"," Petropress $27(2011)$.
} 
indigenous classes, one that became central to creating possibilities and strategically positioning the TIPNIS conflict as one of national concern.

\subsection{Organic intellectuals and the production of practical knowledge}

For Gramsci, the maintenance, contestation and reproduction of the capitalist mode of production is driven by two forces, coercion and consent. The function of hegemony serves to reinforce the domination of the elites over civil society, whereas directdomination is mediated through the "state" or juridical government. ${ }^{254}$

The cohesion and strength of the domination of the historic bloc is effective when hegemony is used along with coercion, and is strongest when coercion is barely revealed at all. ${ }^{255}$ Consent, therefore, is integral to the endured existence of domination, given that knowledge is produced by the dominant classes and consumed, contested and reproduced by the subaltern and working classes as 'common sense.' To construct a counterhegemonic project, the working and subaltern classes must collectively organize through active engagement with their material conditions but also through the production of a counter hegemonic set of ideas, or "good sense." Some of the key facilitators of this revolutionary process are organic intellectuals. Organic intellectuals emerge from an "active participation in practical life as a constructor, organizer, 'a permanent

\footnotetext{
${ }^{254}$ Gramsci, Selections from the Prison Notebooks, 12.

${ }^{255}$ When the MAS attacked the TIPNIS march this revealed a crack in the hegemonic fabric and resulted in a catalyzation of popular mobilization.
} 
persuader." ${ }^{256}$ Organic intellectuals become 'specialized' and political through active participation in the creation of ideas.

Whereas for Gramsci, intellectuals work within their class to reproduce the status quo, which does not disrupt common sense, organic intellectuals can actively level their class position through the production of common sense. This works towards uniting the subaltern and working classes. Organic intellectuals must constantly work and engage practically in order to unify and facilitate both the production of ideas as well as the subaltern and working classes for the "assimilation and conquest" hegemony. Seeing that the MAS has managed to maintain a hegemonic bloc for some time which has major grounding in various popular sectors through its management of hegemony-practical engagement which expands beyond the production of discourses and ideas can is essential in revealing the disaccord between economic, political and cultural change.

Since organic intellectuals contribute to the production of practical knowledge to build and strengthen alliances between the working and subaltern classes- this also makes room towards decolonization of power relations possible, and the diminution of interclass divisions grounded in racial/ethnic/colonial tension, a means towards producing commonalities of struggle. Practical knowledge, then, in terms of political mobilizing, could be viewed as the ways in which key producers of knowledge are able to politically mobilize various sectors in the production of hegemony/counter-hegemony.

\footnotetext{
${ }^{256}$ Ibid, 10.

${ }^{257}$ Ibid.
} 
While in the Vigilia San Francisco, the intellectual/organic intellectual presence was quite visible. Equally as visible was the way in which organic intellectuals were effectively contributing to a broadening of alliances and a decolonization of expertise and intellect. CONAMAQ and CIDOB, the two organizations living in the vigil, had their own internal "insider" political advisors. These advisors, internally elected, would sleep and live in the vigil, and often simply arranged meetings and facilitated discussions. These advisors were often central to the continued political engagement by these organizations. One advisor in particular, Toribia Lero, ${ }^{258}$ a woman from the ayllus of Cochabamba, was extremely important for working with various other sectors, arranging meetings, and resolving internal and external conflict as it emerged. She also maintained a presence in marches and press conferences and helped in meal preparation.

There were also the "outsider" advisors, the "intellectuals," members from the urban middle class who would come into the vigil, give their expert opinion on strategy or tactics, and then leave. These people often belonged to various NGOs or research institutions; some white, ${ }^{259}$ all educated, and all young. They often entered the vigil and appeared rushed to leave. They would give long-winded speeches and then would make themselves available for questions, and collaborate on the production of written statements. There were other "outsider" actors, however, who took on a different role that

\footnotetext{
${ }^{258}$ Official position of CONAMAQ, Support of Organic Incidents: Ayllus de Cochabamba.

${ }^{259}$ When I say white here, I literally refer to American or European. Rafael Quispe in particular often had one or two white male advisors that would come and sit in on meetings, taking notes. They were not researchers, and their positions were kept quiet- no one was sure of who they were or what they were doing, but they often only entered during large vigil meetings and discussions.
} 
could clearly be interpreted as the permanent persuaders and political organizers Gramsci was referring to.

In particular I am referring to an NGO that had a persistent ( 24 hour) presence in the vigil. ${ }^{260}$ This organization contributed not only to the active production of political practical knowledge, it also contributed to a de-colonization of the dynamics of power between the urban middle classes and the rural indigenous and campesino communities with whom they were working. Instead of going into to vigil to "educate" or "tell" the indigenous organizations what their next move should be, instead of writing their documents, responses, and analyses for them, they opted to provide support. They offered their help to being a liaison with the media, and they contributed to the day-today labour that was required to ensure the survival of the vigil. Politically this organization provided the indigenous organizations with a breadth of knowledge and information. They gave presentations on the TIPNIS highway, of the economic and political motivations behind the project, they invited other academics and indigenous people to come and speak of their experiences with the project. Further, they maintained a large database of press and media coverage that was up-to-date. Daily they would present any issues to the attention of leaders and the mamas within the vigil. Finally, using the contacts that they had, and continued to collect over the six-week period, they kept in touch with other popular sectors (COB, FSTMB, Maestros) expressing their support, helping to arrange meetings so that indigenous leaders of CONAMAQ and CEPLAP could meet and strategize with these sectors.

\footnotetext{
${ }^{260}$ In order to protect the organization from governmental scrutiny and possible funding/donor problems the name of the organization as well as its members will be kept anonymous.
} 
What is essential about their presence in the vigil is two-fold. Firstly, they maintained a daily presence, which meant that, despite their middle class status they slept and ate in the vigil with the organizations in order to maintain a level of trust and camaraderie. Second, their sense of what their role was not to "inform" or to "tell" the indigenous organizations what to do. They were completely aware of these organizations`abilities to produce and act politically as organizations. Instead, they felt their role was to provide as much information as possible to permit for the rolling out of politics through debates, discussions and presentations. This methodology proved to be extremely effective. In fact, due to some on-the-spot diligence members from CONAMAQ and CEPLAP were able to meet with and discuss with the COB and Maestros unions respectively two players who became central and maintained a physical presence throughout the conflict.

\subsection{Criticism, debate and the Intellectual and Urban Class}

With the release of the LRPCA and the increasing popular skepticism by the MAS the urban intellectual class began mobilizing to create spaces for intellectual debate, conversation and criticism holding public meetings in the cities of Cochabamba and La Paz. As such a group of intellectuals including Alejandro Almaraz, Raul Prada and Gustavo Soto along with activists and militant campesinos formed and collaborated to produce the Manifiesto de la Coordinadora Plurinacional de la Reconducción Por la Recuperación del Proceso de Cambio para el Pueblo y con el Pueblo. Their first official meeting was held in Cochabamba on July $1^{\text {st }}$. 
This group, a collection of activists, intellectuals and leaders of campesino organizations met and collaborated to produce a document to steer the proceso de cambio away from transnational and colonial dangers of the past. They identified key areas of economic and political shortcomings of the government; including the failure to truly nationalize hydrocarbons, the MAS failure to invest into the public sector with their reserves, and the continued persistent movement towards being a capitalist extraction economy. They clearly criticize the MAS for claiming on one hand to be the protector of mother earth, while introducing transgenic seeds and engaging in extraction processes that are continued to destruct the environment. ${ }^{261}$

According to one of the signing members of this loosely organized group, the value of what they were trying to accomplish lay in the production of knowledge and politics.

Creo que el valor de ese manifiesto, y de ese grupo esta en abrir un espacio plural de discusión y de critica al proceso de cambio, pero que no se enuncia desde la oposición neoliberal, que no se enuncia desde la tradición conservadora de la política boliviana, si no que se enuncia también desde un espacio de izquierda crítico, ¿no? Entonces, creo que la intención no es situarse contra el proceso de cambio, sino señalar y de hacer evidente sus limitaciones y tratar de profundizar este proceso, ¿no? ${ }^{262}$

Contrary to criticisms denouncing the Manifiesto, this group was not trying to get rid of

Evo Morales, or completely reject the MAS or the MAS' project, but rather they recognized the dangers in the directionality of the present tendencies. Instead they were attempting to re-situate what they felt was the core of the proceso de cambio, a political project to live better, which constantly required maintenance and struggle from Bolivians.

\footnotetext{
${ }^{261}$ See report fully published in Bolpress June 25, 2011. Available online: http:/www.bolpress.com/art.php?Cod $=2011062207$

${ }^{262}$ From interview with Jorge Komandina.
} 
...en Bolivia hay un espacio enorme de discusión, de reflexión, deliberación en todo los ámbitos; es decir siempre se esta reflexionando en todos partes, en Bolivia es lo bueno digamos de este proceso, que la gente siempre esta pendiente de todo que pasa y cualquier cosa que percibe, considera de que no es lo correcto, entonces sale como con el gasolinazo del 2010, ¿no? La idea del manifiesto es justamente establecer, pero de manera mucho mas ordenada, mucho mas... hum, como diríamos... mucho mas rica en cuanto a todo lo que se ha podido avanzar hasta ahora, y las dificultades que se han tenido, es poner sobre la mesa todo esto, escuchar mucho a la gente, y otra vez establecer la construcción de una base social fuerte y vigorosa, clara, y con propuestas que pueden ir empujando este proceso, no empujar al gobierno pero si al proceso $¿$ no? ${ }^{263}$

Although these meetings were important for stimulating not only critical discussions within and between the middle and urban classes, they also attracted the attention of the MAS. In response to the Manifiesto, Vice-President Garcia Linera wrote a formal response in the form of a book ${ }^{264}$ criticizing the group of indignados of being right-wing opportunists, producing lies to the general public about what was happening economically and politically in Bolivia. Further, members of the MAS executive constantly made public efforts to de-legitimize their work, calling Almaraz and Olivera power-hungry opportunists, denouncing the work they had done in the past for the country, and running slander campaigns against them. ${ }^{265}$

The work of the Manifiesto was successful in that it ignited an antagonistic critical dialogue, if somewhat hostile, between the government and civil society. That being said,

\footnotetext{
${ }^{263}$ From interview with Oscar Olivera.

${ }^{264}$ Alvaro Garcia Linera, El "OENEGISMO" enfermedad infantil del derechismo: O como la "reconduccion" del Proceso de Cambio es la restauracion neoliberal (La Paz: Vicepresidencia del Estado Plurinacional, 2011).

${ }^{265}$ As the group began their criticisms the government began their counter campaign. Cesar Navarro, vice minister of the State was quoted calling the group "derechistas" Later, following the violent repression of the march Wilfred Chavez was quoted attributing the blame of the repression to political instigators Almaraz and Olivera. From "Los indígenas del Tipnis rompieron ayer con violencia un cerco de seguridad, en el noveno intento del Gobierno de dialogar, "El Cambio, 25th of September, 2011.
} 
the Manifiesto did not, in this case, provide practical knowledge that would result in catalyzing popular mobilizations around the issues that they were raising in the Manifiesto. For Almaraz, the middle classes in Bolivia have always been important swing players in massive mobilizations, ${ }^{266}$ and in fact, the middle class played a key role in October of 2003. Even if these intellectuals were not in that moment capable of mobilizing the popular classes, these conversations continue to stimulate academic debate, which is centrally important to the continued construction, popular or not, of the Bolivian proceso de cambio. Perhaps what the manifiesto lacked was a more popularized use of tactics. One movement leader voiced her concerns of the tactics of the Manifiesto at one of their meetings:

...también he conocido a los nombres, hermano Alejandro Almaraz, hermano Oscar Olivera. Pero hermanos, hermanas, yo... dos preguntas tengo ¿no? lo ultimo es reflexionar a todos ¿no?, ya estoy volviendo muy triste, preocupada. Ya bastante hemos hablado; Hermanas, hermanos, es muy triste aquí estamos mayoría profesionales, también ¿no? No me gusta, llegar a perjudicar al tiempo, hablar igual discursos, discursos y después para nada hermanos, hermanas... ${ }^{267}$

Instead of producing knowledge that was disseminated among the subaltern classes, the work that the intellectuals engaged in served to re-ignite debates that had been bubbling since the election of the MAS. Asunta recognized the importance of these discussions but was concerned of how they would be implemented practically; how would this be dispelled to her community outside of the city? She went on to say that rural communities answer to their member unions: that was where politics occurred in rural areas. But, no one had been invited to come out, and less, no one was making an effort to travel out to work on informing those bases. There appeared to be a disconnection between how to

\footnotetext{
266 Almaraz, Obras Completas.

${ }^{267}$ Asunta Salvatierra, President of MST-CBBA. Speech given at Manifiesto Meeting, July $1^{\text {st }}, 2011$.
} 
tactically mobilize the middle and urban classes, and how to expel those linkages to the rural and subaltern populations- work that required much more attention.

Although the manifiesto had begun to tackle transgenic seeds as yet another indication of the wavering of the proceso de cambio, or capitalist tendencies of the MAS, this group of intellectuals did not use their expertise to generalize or popularize that knowledge. Perhaps more effective tactics to that end involved the active popularization of knowledge which some member of the Manifiesto engaged in to their own initiative. Some individual members continued to work for their respective institutions and organizations, some in ways that were more organizationally important than others. Moises Torres, the vice-president of the MST with the MST-Mujeres of Cochabamba, proceeded to organize a weekend information session for all of the leaders of MSTTierras Altas to inform their campesino producers of the potential dangers of genetically modified seeds. These meetings were important for engaging leaders who could take information back to their respective communities and discuss actions.

I am not attempting to suggest that "intellectual" work is unimportant or does not serve a purpose in Bolivia. In fact, the intellectual production of information is extremely important for battling out these ideas that ultimately will define the ways in which this proceso de cambio continues to contest and re-create the political sphere. Intellectuals can be very important for moving beyond the "moment-ness" of a conflict, capable of linking the tendency/longevity of politics to its temporal specificity. However, in the Gramscian sense of "organic intellectual", some institutions were more effective in using 
their "intellectual" capacities for disseminating knowledge that mobilized solidarity

within distinct sectors. From these actors we can see the ways in which the production of "academic knowledge" can be generalized to contest the dominant hegemony and spread to dirigentes, bases, and communities who mobilized against the TIPNIS highway.

\section{3 “Ahora es la époqua de los mineros"268}

As support for the march grew we began to see the re-emergence of popular sector solidarity. One of the most important expressions of solidarity came out of the XXXI Congreso de la Federacion Sindical de los Trabajadores Mineros de Bolivia (FSTMB) on September 11, 2011 when the miners union of Huauni announced;

Apoyo y solidaridad activa y militante a los companeros del Teritorio Indigena del Parque Nacional Isiboro Secure, por ser atentatorio contra los bolivianos, que no favorecera en nada a nuestro Pais, mas al contrario a las transnacionales por lo tanto exigimos que el Presidente del Estado Dn. Juan Evo Morales Ayma atender las demandas e persona a nuestro companeros a la brevdad possible y dar solucion definitive a este conflicito. ${ }^{269}$

Support from the national mining union was significant and yet revealed the complexities of inter-popular sector alliances and the difficulty of forging alliances within communities that have internal tensions and complex histories of struggle.

\footnotetext{
268 Tata Miguel, leader of CONAMAQ from Chichas province, Potosi.

269 FSTMB: Resolucion Expresa No.3: Apoyo y solidaridad con los companeros del TIPNIS. September 10,2011 .
} 
The relationship between mining communities and indigenous communities is a difficult and tense one. Often it is the case that when mining companies enter into communities they engage in a destruction of the surrounding environment, which ultimately translates into a degradation of the community. ${ }^{270}$ Agricultural producers suffer, as do the community members at large as they experience the degradation of their livelihoods, and the environment. ${ }^{271}$ For miners, especially in a country like Bolivia, where work is scarce and essential to survival, work is work. Despite the rhetoric of the MAS, transnational mining companies still have little accountability to environmental preservation and extraction practices, and have continuously failed to enter into true environmental repair contracts with communities who have experienced environmental destruction. ${ }^{272}$ So, workers become pitted against communities, which is favorable for the company who has set up shop in that area, with the weakening of alliances and resistance to that company. Ultimately the TIPNIS conflict provided an arena for the discussion of these issues, and the emergence of potential alliances between workers and indigenous communities.

After its initial support for the TIPNIS march, the FSTMB began to distance itself from the conflict. The reasons for this are complicated but lie in some of the demands that the CIDOB/TIPNIS/CONAMAQ march produced surrounding the stoppage of extraction

\footnotetext{
270 Vladimir Diaz. "La mineria bajo el dominio de las transnacionales," Petropress 25 (2011).

271 Presentations by various South American researchers, 9-11 November. Jornadas sobre la megamineria boliviana. (Cochabamba: CEDIB, 9-11 of November 2011). Slides available online at: http:/ www cedib org/presentaciones/.

272 Jorge Campanini, "Environmental Impacts of Megamining, " Jornadas sobre la Megamineria. (Cochabamba: CEDIB, 11 th of November, 2011).
} 
projects in mining communities ${ }^{273}$, the infiltration of some Right-Wing opportunist groups and some internal/organizational conflicts that they too were facing at the time. And so, as a union, despite their participation in the $\mathrm{COB}$ general manifestation following the repression, and a few select meetings, their active engagement and support was limited. However, the topic of miners and the political economy of mining in Bolivia was a reoccurring discussion point within the vigil, especially within the members of CONAMAQ. On several occasions, the mama and Tata autoridades would enter into talks as to whether or not they should accept the support of the miners based on some previous history and experiences of conflicts between miners and indigenous communities, some of which had turned violent in the past. Instead of writing off the FSTMB, however, various communities of CONAMAQ engaged in very rich and important discussions regarding the importance of political alliances. Mama Catalina argued that miners are their indigenous brothers too, and that their support only made them stronger. She also claimed that inter-sectoral support, not only from the miners but also from the $\mathrm{COB}$ and maestros was crucial for building alliances, something the government was attempting to dismantle:

...hemos aprendido que es reunidos que tenemos fuerza. Entonces nosotras también estamos interesadas en sus propuestas y en sus demandas y nos hemos dado cuenta que este gobierno se está acostumbrando a no responder a los intereses del pueblo y que siempre quiere dividir. ${ }^{274}$

Other tatas in the vigil argued that this time was "la epoca de los mineros" in Bolivia, and that if the miners could think like indigenous people, as indigenous people, then alliances

\footnotetext{
273 of the 10 points which the CIDOB released prior to the police repression as their demands revolved around the cancelation of existing or pending extraction projects. which essentially meant for the FSTMB's members the potential for losing work.

${ }^{274}$ CEDIB, "Entrevista: Las vigilias por el TIPNIS."
} 
could emerge which could prove beneficial not only for indigenous communities but for miners who live in those communities as well. The national-popular discourse even emerged within these discussions with an authority of CONAMAQ arguing for nationalization and expropriation of existing transnational mining interests. According to him, “...porque frente a los transnacionales, ni los trabajadores, ni los indigenas tienen cuenta. Aunque hay la posibilidad con el gobierno de tener un voz, de controlar la manera de explotar, para proteger nuestros territorios." This sentiment was echoed and continued to surface during the popular-sector support for the march, which escalated after the violent repression, (or massacre as it is now referred to) by those who lived in the vigil, on September 25.

\subsection{Popular sector alliances and the re-ignition of the national popular and indigenous sectors}

Not only were the indigenous highland and lowland organizations uniting against the MAS government and the TIPNIS highway, but the conflict also catalyzed a popular based support movement against the capitalist tendencies of the MAS.

After the oppression of the march on September 25, the political tension around the issue moved from tense to volatile. The move from consent to coercion around the project by the MAS government caused many MAS supporters to question the acts of the government. It also served to catalyze the popular-working class sectors of society who 
immediately began calling general assemblies to discuss the TIPNIS. Following the repression, the COB called for a national general strike to support the TIPNIS, and on September 28 the two-day national general strike began with nation-wide marches and manifestations in 6 major cities. In La Paz, various sectors marched in solidarity with the TIPNIS and against the MAS' immediate decision of violence against a peaceful indigenous march. ${ }^{275}$

The COB and the national teachers union emerged at the forefront of popular-sector solidarity. These sectors, especially the maestros had an unrelenting support and presence following the repression of the march in La Paz. They held forums, organized manifestations, and participated in the COB general strike, which was launched, somewhat unsuccessfully, following the police repression across the country. The TIPNIS conflict provided opportunity for the working class and urban sectors to gather and discuss as well as collaborate with the indigenous leaders of CIDOB/CONAMAQ/CEPLAP. The vigil became the space where leaders of the maestros, for example, would show up to strategize, in addition to show their support.

Following the general $\mathrm{COB}$ mobilization and strike, the "mitin" (a public speech giving forum) was held directly in front of the vigil, and members of CONAMAQ and CEPLAP were invited to speak in conjunction with miners, teachers, and other public sector workers. Although there was not complete agreement within or between these sectors, a broader ideological and political support bandage was maintained against the MAS'

${ }^{275}$ ERBOL, "Masivas movilizaciones en 9 regiones repudian violencia policial contra indigenas," Erbol, $28^{\text {th }}$ of September, 2011. 
capitalist politics. These were seen as dangerous and threatening to the popularly imagined proceso de cambio and the demands, although particular to each sector, converged around - the de-neoliberalization of the MAS' political tendencies, - the expulsion of ministers who were viewed as corrupt or dangerous, - as well as the cancellation of TRAMO II of the San-Ignacio de Moxos- Villa Tunari highway, the section which would pass through the TIPNIS territory. None of these groups, including the TIPNIS-CIDOB-CONAMAQ were against the highway per se, rather against the way in which the highway was to be implemented, the process of its conception, and the particular section that would pass through the TIPNIS territory.

For the mamas of CONAMAQ, the presence and persistent support of the COB and the popular working class sectors was a key motivator. For Mama Katalina:

Nosotras hemos luchado con toda la conciencia, con toda la verdad y hemos luchado con razón; y luchando así, buscando la verdad, buscando la justicia, hemos ido a visitar allá a su oficina tanto a la COB, como al Magisterio y con otros sectores que nos demostraban apoyo y solidaridad. $Y$ hemos ido con ellos a discutir por qué y para qué la marcha y también hemos coordinado marchas y acciones y hemos también recibido información de ellos y de sus demandas, nos hemos dado cuenta que ellos como nosotros los indígenas también tienen demandas justas, y ellos como nosotros también necesitamos apoyos, apoyarnos.

The COB's support was critical for giving political and economic weight to the demands of the TIPNIS/CIDOB. Despite the fact that the XIII Marcha had continued to persevere against all odds, and despite the fact that the vigil had remained a central organizing space, the fact remained that really the TIPNIS had little political or economic power against the Brazilian government, against the MAS, or against the corporation IIRSA. With the COB's ability to call general strikes, to blockade major transport highways and 
shut down cities across the country at a call, this provided significant clout to the matter, forcing the government to seriously think about the project.

The TIPNIS march arrived in La Paz, 65 days after its initial departure. The CIDOB/CONAMAQ further forced their move by taking over the Plaza Murillo with a group of about 250 indigenous marchers. With this additional pressure, public outcry from urban pacenos, increasing mobilization from the FEJUVE of el Alto, the recent judicial election upset ${ }^{276}$, and the $\mathrm{COB}$ threatening to escalate actions the government agreed to meet with the marchers. On October 21 Evo Morales determined the TIPNIS territory "intocable" and produced the Ley Corta TIPNIS preventing the highway from passing through the park. At this point the vigil and Plaza Murillo occupation were dismantled. Despite the government claiming the territory untouchable, it is important to note, that the contract with Brazil and the IIRSA was not cancelled. As such, in January following the national cumbre, the government announced that the Ley Corta TIPNIS would be revised, that the TIPNIS communities would be consulted again, and that the highway San Ignacio de Moxos- Villa Tunari was back in the works.

Even though the conflict partially fragmented and disseminated, popular mobilizations have again resurfaced and have done so in a more complex and potentially dangerous way. Some of those dangers I have discussed elsewhere, and for the purposes of this particular study I highlight this case as exemplary of the ways politics unfold and manifest in times of political and economic turmoil, as well as to define the sheer

\footnotetext{
${ }^{276}$ Largest nullified vote results in Bolivia's history, a campaign that was lead by the MSM right-wing opposition party.
} 
importance of broad-base alliances for constructing alternatives. In the end, the emerging Brazilian capital interests in Bolivia have preserved in the short run, outweighing the ability of these mobilizations to truly modify the MAS' politic of the present. However, what emerged from this conflict is the re-catalyzation of popular mobilization, a recatalyzation that is bubbling and conscious of the MAS' present political and economic alliances and tendencies.

What makes the TIPNIS conflict important for our analysis is two-fold. First, it represents a moment in political conjuncture that opened up possibilities for political mobilization not only by the Left, but also for the Right wing to capitalize on the struggle for hegemony over the conflict. Second, it demonstrates a larger politic of division that is becoming more and more common in Bolivia's recent political history, a story of interclass tension and conflict over the property of natural resources, whilst the larger political-economic context suggests the continued sale to foreign interests of the major portion of them. That being said, the TIPNIS conflict, as a moment in political conjuncture, enabled not only the fragmentation but also the formation of other alliances that could prove to be important in the years to come. 


\section{$5.5 \mathrm{El}$ "como" y la recuperacion del proceso de Cambio." Herein lies the politics of possibility.}

As we have seen through out this examination the MAS government has entered into a new realm of political conjuncture and is struggling to maintain hegemony in light of increased political and civil dissent by the very popular and indigenous classes that propelled the party into power. As demonstrated in the early sections of this study, there are clear contradictions between the discourse being used to propagate the MAS' hegemonic stronghold and the practical actions and political tendencies of the MAS government as of late. The MAS' failure to adequately reform land and territory and develop a land policy that counters transnational and elite interests has lead to a remobilization of the national-popular and indigenous sectors that are taking up the calls of the early 2000s. The gasolinazo conflict that erupted in 2010 from an increase in the price of petroleum incited mass widespread popular mobilizations, and widespread public scrutiny regarding its political orientation. Since that time, the government has failed to fully recuperate its image.

Specifically, this investigation sought to analyse the MAS' political positioning on agricultural production, which, as I have shown, has yet to be re-organized in a way that truly confronts the elite and transnational agro-industrialist classes. Instead, the MAS holds the position that, beyond their discourses of the environment, indigenous rights, 
and new socialism, presently benefits the expansion of capital. The unfortunate movement of this recognition is that it serves not only to continue to exacerbate the experiences of poverty and marginalization for indigenous, campesino, and working-class Bolivians, but that it violates the demands that coalesced and emerged following the massive popular uprisings of 2000 and again in 2003 . With the continued concentration of land in the hands of capitalist agro-industrialists, campesino and indigenous communities alike are forced to fight for what remains, which is insufficient even to begin thinking about national agricultural sovereignty. Instead, as these examples reveal, mounting tensions within the subaltern classes serves to obfuscate the real political and economic powers at play. As a result it is extremely important to think about the ways in which the Right Wing can capitalize on these divisions in the first place, and beyond government political parties, the ways in which capital can expand and exacerbate these mounting divisions.

I suggest that before the MAS government can begin talking about food sovereignty and indigenous rights, it needs to engage in a true revolutionary process. A process to ensure that more concrete political policies can be put into place to guarantee developments. In order to maintain the image that brought about its existence, there is an essential necessity to work towards re-directing the target of political conflict away from the subaltern classes and towards those who continue to benefit from mounting divisions and tensions. As such, the complete expropriation of agro-industrial capitalists is elemental to any further advancement. In addition, the government needs to make true efforts to strengthen agricultural production, which will enable food sovereignty for all Bolivians. 
Promoting agricultural production for export, the promotion of agro fuels, and legalizing genetically modified seeds will only act as barriers (and even destroy) revolutionizing agricultural production. That being said, however, the issue is clearly complex.

Simply expropriating agro-industrialists without also taking into consideration the liberal ideology that is continuously imposed onto indigenous and campesino communities will not result in the socialization or communization of agricultural production. The role of organic intellectuals, that is to say, research institutions that those that participated in the vigilia, but also campesinos and indigenous communities who have experience with agricultural production need to take the lead in socializing, and engaging in the conquest of the hegemony of capitalist-liberal organization of land and production. This process must occur with the expropriation of large-scale industrial landholdings, and it must be clarified that, given the political and economic stronghold of this particular elite, this expropriation would not occur without violence.

The current tendency of the MAS administration in agriculture reveals an age-old politic that has continued to haunt the Bolivian political-economic trajectory, that of a primaryresource extraction industries. If Bolivia continues to allow for the expansion of the agroindustrialists in the media luna region, their position will continue to remain subordinate and susceptible to highly volatile markets and price regimes, to foreign capital, and climate change. 
Much like the Centro de Documentacion e Informacion Bolivia (CEDIB) has revealed in their investigations in hydrocarbons and mining, Bolivia was and has continued to be, since colonial times, a primary-resource producing nation. Maintaining a politic that continues to pursue this trajectory will continue to permit that capital takes all and leaves nothing. That nothing becomes what, as we saw in the final section of this investigation, the popular classes are left to fight over: scraps.

That being said, the future is anything but written for Bolivia. What makes Bolivia central for investigations founded in the politics of possibility is the active nature of the politics, and the central dynamism that challenges strict "state" - "civil society" binaries. The unrelenting push of the popular sectors and the constant re-imagining of political possibilities, continues to produce moments of conflict absolutely necessary for the construction of a politics that enables Bolivians to "vivir mejor." Bolivians continue to "battle-out" politics in moments of political conjuncture, moments which not only serve to challenge the immediate, but also are critical for political formation and building solidarity for the future.

As the final two sections revealed, the indigenous and national-popular sectors are again mobilizing to recuperate their vision for the future of their country. Demands centered and grounded in ownership and distribution of natural resources seek to mobilize and unify Bolivians, and are resulting in the production of widespread and interesting strategic political alliances between indigenous communities and working popular sectors. Such alliances are extremely important to combat the continuous penetration of 
transnational capitalist interests. The only way these alliances can be fully realized, however, is by unification within and between the popular and subaltern classes.

What is clear is that this re-mobilization has resulted not only in a questioning of the MAS' politics yet again, but it has also provided unclear opportunities for Right-Wing political mobilization, and fragmenting between and within the indigenous and campesino sectors and popular classes. As we have seen, Bolivians have a clear and unrelenting history of struggle against colonial and capitalist oppressors, old and new. These more contemporary events, or moments in its political history will surely affect the ways in which mobilizations continue to build and alliances to grow. And with elections rapidly approaching in 2013 the ways in which these popular sectors mobilize and unify are especially critical to confront the "push-back" of the capitalist elite.

Bolivia provides us with a case for further examination into the means in which political alternatives are constructed, maintained, and reclaimed. It is clear that Bolivians within the national-popular and indigenous sectors know what they envision for the future of Bolivia, the difficulty comes from the long and difficult road they must travel to get there. Political systems do not exist in vacuous spaces, and transnational capital is anything but unrelenting. Hope, as well as the possibilities for future contestation and struggle exists in the equally unrelenting ways in which Bolivians unite and resist; under even the most ideologically or physically oppressive circumstances. The MAS government emerged from the blood of massacred Bolivians fighting united to live better, with the unprecedented support and trust of the subaltern and popular classes. The ways 
in which politics unfold from here cannot be removed from that past, but the steps that are taken to get there will reveal moments central in the formation of what is envisioned for the future, and how that vision becomes implemented practically.

Que los transnacionales no enfrente al pueblo boliviano!!Jallalla Bolivia! 


\section{Appendices}

\section{Appendix A: Abbreviations}

ANAPO: Asociación de Productores de Oleaginosas y Trigo

AOPEB: Asociación de Organizaciones de Productores Ecológicos de Bolivia

CAINCO: Cámara de Industria, Comercio, Servicios y Turismo de Santa Cruz

CANEB: Cámara Nacional de Exportadores de Bolivia

CEDIB: Centro de Documentación e Investigación Bolivia

CIDA: Canadian International Development Agency

CIDOB: Confederación de Pueblos Indígenas de Bolivia

COB: Central Obrero Boliviano

CONAMAQ: Consejo Nacional de Ayllus Markas Qullasuyu

CNMCIOB-BS: Confederación Nacional de Mujeres Campesinas Indígenas Originarias de Bolivia- Bartolina Sisa

CSUTCB: Confederación Sindical Única de Trabajadores de Bolivia

FAO: Food and Agriculture Association

FES: Función económico-social

FINPRO: Fondo para la Revolución Industrial Productiva

FONTAGRO: Fondo Regional de Tecnología Agropecuaria

FSTMB: Federación Sindical de Trabajadores Mineros Bolivianos

GMO: Genetically Modified Seeds

INIAF: Instituto Nacional de Innovación Agropecuaria y Forestal

IFI: International Foreign Investment Institutions

LRPCA: Ley de la Revolución Productiva Comunitaria Agropecuaria 
MAS: Movimiento al Socialismo

MNR: Movimiento Nacional Revolucionario

MST: Movimiento Sin Tierra

NCPE: Nuevo Constitución Político del Estado Plurinacional de Bolivia

OECOM: Organizaciones Económicas Comunitarias

TCO: Territorios Comunitarios de Origen

TIPNIS: Territorio Indígena Parque Nacional Isiboro Sécure 


\section{Appendix B: Methodology}

This project is the result of nearly seven months of fieldwork participating and working with indigenous organizations, primarily in Cochabamba and La Paz, Bolivia. In the first five months of fieldwork I lived in Cochabamba, travelling to and from La Paz. The indigenous organizations with whom I worked primarily during this time were the Consejo Nacional de Ayllus y Markas del Qullasuyu (CONAMAQ) and the Movimiento Sin Tierra de Tierras Altas (MST-A). At the time of the investigation, CONAMAQ was a critical member organization of the Pacto de Unidad, and the MST previously pertained to the Pacto de Unidad. Since this investigation concluded, CONAMAQ officially withdrew from the Pacto de Unidad. During this period of time (May-August) I attended conferences, workshops, protests, assemblies, meetings, and presentations related to the two struggles that these organizations were simultaneously involved in. The first being the introduction of the new Ley de la Revolucion Productiva Communitaria Agropecuaria, and the second being the conflict surrounding the controversial construction of the highway Villa Tunari-San Ignacio de Moxos in the parque Isiboro Secure.

In the second half of my fieldwork, I lived in, participated and supported the "Vigilia de San Francisco" that was initiated by CONAMAQ in La Paz for nearly 6 weeks, until it was officially dismantled. During this period of time I worked with CONAMAQ, CIDOB and CEPLAP doing whatever tasks they required me to do in order to support the XIII March de Tierra $y$ Dignidad and maintain the solidarity vigil. During this time, I slept in the vigil with the indigenous authorities; attended their meetings, participated in the 
marches they organized, contributed to and helped in organized daily press readings and provided technical support when requested. It was during my second phase of fieldwork that the political climate in Bolivia became particularly tense- evolving from the violent repression of the march by the MAS government on September 25, 2011.

My fieldwork methodology in Bolivia developed into what Philipe Bourgeois refers to as engaged anthropology. I became an active political participant, attempting to participate or observe all that I possibly could. After the police repressed the TIPNIS march on the 25 of September, things turned from tense to hostile, with massive mobilizations erupting from five major cities across the country, to be followed with general strikes, massive marches and protests.

In the collection on the role of engaged political research for studies Schatz argues that, "person-to-person contact that is attuned to the worldviews of the people we study is invaluable for a science of politics." ${ }^{277}$ Once the government oppressed the TIPNIS march, I interpreted this as an important and critical conjuncture moment, and opted to stay in La Paz living in the Vigilia San Francisco. At that point I did not have my laptop or my voice recorder. I decided that since the mama leaders of CONAMAQ were opting to take political positioning against the government's actions this would be the best place for me to be. I ended up staying in the vigil for five weeks, when it was then dismantled. This decision proved absolutely essential for me to understand, observe and participate in

\footnotetext{
${ }^{277}$ Edward Schatz. "Introduction: Ethnographic Emersion and the Study of Politics", in Political Ethnography: What Immersion Contributes to the Study of Power. Ed. Edward Schatz. (Chicago: The University of Chicago Press, 2003), 4.
} 
the unfolding of the TIPNIS conflict as it mounted to its most tense moments in September and October of 2011.

This work is critical with the hope of stimulating debate and generating alternatives. Along this line of reasoning, it is important to identify this project as one that is critical but in solidarity with the revolutionary process- in order to differentiate it from criticisms of the Right. If we understand the construction of revolutionary alternatives as a process in the Gramscian sense of the concept, then debate and critical engagement are central to this process.

As such this project is embarking on a political journey with the objective of recognizing and moving forward with what Said aptly described as central to the development of political projects, an acknowledgement of critical consciousness. This project, then, seeks to stimulate debate with the hopes of drawing up alternatives ${ }^{278}$ to influence the proceso de cambio, not only as it exists in Bolivia, but also as it exists in the spirits of those oppressed by capital. It requires a discussion that recognizes pre-existing racial and gendered structures of oppression, but instead focuses on the ways in which older discussions of what we share make us stronger - this project hopes to present a politic of humanity and a politics of possibility.

\footnotetext{
${ }^{278}$ Kaye Warren cautions about working with communities with whom we are politically aligned, but argues that this work is necessary if done critically. She claims that there is a need for activists and leftist scholars to engage in critical explorations of governments or social movements with whom they align politically and that there is a presently a methodological reluctance to do so, i.e through engaged anthropology. See Kaye Warren. "Perils and Promises of Engaged Anthropology: Historical Transitions and Ethnographic Dilemmas," in: The Engaged Observer: Anthropology, Advocacy, and Activism, eds: Victoria Sanford and Asale Angel-Ajani (US: Rutgers University Press, 2010)
} 


\section{References}

Sergio Almaraz, Obras Completas (La Paz: Plural, 1968).

Heber Araujo, Ley de Revolución Productiva Agropecuaria para el Agronegocio y la Banca.(Cochabamba : CENDA, 2011).

Heber Araujo. Etnodesarrollo, Tierra Y Vida: Una alternative a la crisis alimentaria y energetica. (Cochabamba : CENDA, 2010).

Fausto Beltran \& Jose Fernandez. Por Donde va la Reforma Agraria Boliviana? (La Paz: Talleres Graficos Bolivianos, 1960).

Merwin Bohan. Informe de La Mission Economica de los Estados Unidos A Bolivia (Plan Bohan).(Commissioned by US Department of the State, 1942).

Norman Borlaug. The Green Revolution Revisited and the Road Ahead. Online Lecture PDF format. Accessed Online, October 12, 2010.

http://nobelprize.org/nobel_prizes/peace/laureates/1970/borlaug-arlicle html?print .

Jorge Campanini. "Environmental Impacts of Megamining. " Jornadas sobre la Megamineria. (Cochabamba: CEDIB, 11th of November, 2011).

Amado Canelas. Mito y Realidad de la Reforma Agraria (La Paz: Los Amigos del Libro, 1966).

Centro Boliviano de Economia (CEBEC). Estudios Economicos "El aporte de Santa Cruz a Bolivia: Aspectos Socioeconomicos" (CAINCO: Santa Cruz, 2008).

CEDIB. "Entrevista: Las vigilias por el TIPNIS. "Las mujeres no podíamos permitir eso"." Petropress, 27 (2011).

CEDIB. Presentations by various South American researchers, 9-11 November. Jornadas sobre la megamineria boliviana. (Cochabamba: CEDIB, 9-11 of November 2011). Slides available online at: http://www cedib.org/presentaciones/

Walter Chávez, and Álvaro García Linera, 2005, "Rebelión Camba: Del dieselazo a la lucha por la autonomía", El Juguete Rabioso.

Chavez and Mokrani. "Los Movimientos Sociales en la Asemblea Constituyente: Hacía la reconfiguracion de la política. En OSAL." (Buenos Aires: CLASCO, 2007 (22))

Ciro F.S Cardoso. \& Hector Perez Brignoli. Historia Economica de America Latina: Sistemas agrarios e historia colonial (Barcelona: Editorial Critica, 1979). 
Josue de Castro. Geopolitica del Hambre: Ensayo sobre los problemas alimentarios y demograficos del mundo. (Buenos Aires: Solar Hachette, 1963).

Annette Desmarais. La Via Campesina: Globalization and the power of peasants. (Winnipeg: Fernwood Publishing, 2007).

Vladimir Diaz. "La minería bajo el dominio de las transnacionales." Petropress, 25 (2011).

Crítica de la Teoría del Poder Constituyente: Los Límites del Proceso Constituyente Boliviano. (La Paz: Instituto de Investigacion, Capacitacion y Formacion Democratica "Carlos Montenegro", 2008).

Heinz Dieterich. "The Advance of 21st Century Socialism in Latin America and Europe." The 4th Forum of the World Association for Political Economy (2010): 143-147.

Ruth Duran. Acaso la Tierra Esta Enferma? La experiencia de saneamiento de las tierras comunitarias de origen con CONAMAQ. (La Paz: Stratos Editorial, 2010).

Wes Enzinna. "All We Want is the Earth: Agrarian Reform in Bolivia", in Leo Panitch and Colin Leys (eds), Socialist Register 2008: Global Flashpoints, Reactions to Imperialism and Neoliberalism. (2007).

Nicole Fabricant. "Ocupar, Resistir, Producir: Reterritorializing Soyscapes in Santa Cruz." In, Remapping Bolivia: Resources, Territory and Indigeneity in a Plurinational State. Eds: Nicole Fabricant \& Bret Gustafson. (Santa Fe: SAR Press, 2011).

Elizabeth Fitting. The Struggle for Maize: Campesinos, Workers, and Transgenic Corn in the Mexican Countryside. (United States: Duke University Press, 2011).

Fundacion Tierra. . "El Presidente anunció la paralización de la Función Económica Social (FES)." Website: Fundacion Tierra, $22^{\text {nd }}$ of January (2012).

Kirsten Francescone. "Marching for Land, Dignity and the Proceso de Cambio." The Bullet, 540 (2011).

"Internal Fractions and the right in Bolivia". The Bullet, 548 (2011).

Frederico Fuentes. "Government, social movements, and revolution in Bolivia today: A response to Jeffery Webber." International Socialist Review, 76, March-A pril (2011).

Alvaro Garcia Linera. El "OENEGISMO" enfermedad infantil del derechismo: O como la "reconduccion" del Proceso de Cambio es la restauracion neoliberal. (La Paz: Vicepresidencia del Estado Plurinacional, 2011). 
Lesley Gill. Teetering on the Rim: Global Restructuring, Daily Life, and the Armed Retreat of the Bolivian State (New York: Colombia University Press, 2000).

-.----Peasants, Entrepreneurs and social Change: Frontier Development in Lowland Bolivia: Westview Special Studies on Latin America and the Caribbean. (London: Westview Press, 1987).

Mark Goodale. "Reclaiming Modernity: Indigenous cosmopolitanism and the coming of the second revolution of Bolivia." American Ethnologist. 33(2006): 634-649.

Antonio Gramsci. Selections from the Prison Notebooks. Ed. Smith and Hoare (New York: International Publishers, 1971), 210.

Walter Guevara. Plan Inmediata de Politica Economica del Gobierno de la Revolucion Nacional. (La Paz : Departamento de Prensa Internacional y Publicaciones,1955),45.

Susan Healey. "Ethno-Ecological Identity and the Restructuring of Political Power in Bolivia." Latin American Perspectives 36(2009): 83-100.

Herbert Klein. Historia de Bolivia (La Paz: Libreria Editorial G.U.M, 2000)

Maria Lagos. Autonomy ad Power: The Dynamics of Class and Power in Rural Bolivia (Philadelphia : University of Pennsylvania Press, 1990).

Isabella Margerita. El Poder de la Tierra. (La Paz: Plural, 2008)

Jose Carlos Mariátegui. 7 Ensayos de la Realidad Peruano. (Lima:Biblioteca "Amarta" 1928), 35 .

Karl Marx. Introduction: The Grundrisse Notebooks. (New York: Penguin Classics).

Gustavo Medeiros. "Evolucion y Caracteristicas del Sector Soyero en Bolivia." In: Los Barones del Oriente: El Poder en Santa Cruz Ayer y Hoy (Santa Cruz : Fundacion Tierra, 2008).

Gina Mendia y Guisela Lopez. "Campesinos en Contra de cultivos transgenicos." $E l$ Deber (2005).

Ministerio de Desarollo Productivo. Atlas de Potencialidad Productiva : Santa Cruz. (La Paz: Ministerio de Desarollo Productivo, 2009).

Paul Nicholson and Nicole Delforge. "Via Campesina: Responding to global systemic food crisis." Development, 51(2008). 
Enrique Ormachea S. Revolucion Agraria o Consolidacion de la via terrateniente? El Gobierno del MAS y las politicas de tierras. (La Paz: CEDLA, 2008).

Raj Patel. Stuffed and Starved: Markets, Power and the Hidden Battle for the Global Food System. (New York: Portobello Books, 2007).

Danilo Paz. Estructura Agraria Boliviana. (Plural: La Paz, 2009), 37.

Victor E Paz. La Revolucion Boliviana: discurso del Jefe Nacional del M.N.R a los delegados de la IX Convencion del Partido el 17 de Enero. 1964 (La Paz: Direccion Nacional de Informaciones, 1964), 12-13.

Nancy Postero. Now we are Citizens: Indigenous Politics in Postmulticultural Bolivia. (California: Stanford University, 2008)

Pablo Ramos. Siete Anos de economia Boliviana (La Paz: Puerta del Sol,1980), 123-128.

Pablo Regalsky. "Las paradojas del proceso constituyente boliviano."

(www.constituyentesoberanat.org: 2009)

Carlos Revilla. "Understanding the Mobilizations of Octubre 2003: Dynamic Pressures and Shifting Leadership Practices in El Alto." In, Remapping Bolivia: Resources, Territory and Indigeneity in a Plurinational State. Eds: Nicole Fabricant \& Bret Gustafson.(Santa Fe: SAR Press: 2011).

Silvia Rivera Cusicanqui. "Liberal Democarcy and Ayllu Democracy in Bolivia: The case of Northern Potosi." (1990).

-.-......... "Luchas Campesinas contemporaneas en Bolivia: El Movimiento "Katarista": 1970-1980. Bolivia Hoy. Ed: Rene Zavaleta Mercado. (Mexico: Siglo Veintiuno, 1983).

Edward Schatz. "Introduction: Ethnographic Emersion and the Study of Politics", in Political Ethnography: What Immersion Contributes to the Study of Power. Ed. Edward Schatz. (Chicago: The University of Chicago Press, 2003).

Michael Schulte. Llameros y Caseros: La economia regional kallawaya. (La Paz: PIEB Investigacion, 1999)

Vandana Shiva. "Un ataque contra los recursos y el patrimonio de los países". Rebellion, 2007.

Jim Shultz and Melissa Draper. Dignity and Defiance: Stories from Bolivia's Challenge to Globalization. (Los Angeles: University of California Press, 2008) 
Lorenzo Soliz and Silvia Aguilar. Produccion y Economia Campesino-Indigena:

Experiencias en seis ecoregiones de Bolivia 2001-2003. (La Paz: CIPCA cuadernos de investigacion, 2005)

SOMOS SUR. Ley de la Revolución Productiva Agropecuaria y Comunitaria: Quien GANA y quien PIERDE (Cochabamba : SOMOS SUR, 2011).

Ximena Soruco. "De la Goma a la soya: El Proyecto Historica de la elite crucena." In, Los Barones del Oriente: El Poder en Santa Cruz y Hoy. Eds: Ximena Soruco, Wifredo Plata \& Gustavo Medeiros. (Santa Cruz: Fundacion Tierra, 2008).

Alison Spedding. Kawasachun Coca: Economia campesina cocalera en los Yungas y el Chapare. (La Paz : PIEB investigaciones, 2005).

Esteban Ticona Alejo. "Organización, liderazgo y representación Aymara en la Confederación Sindical Unica de Trabajadores Campesinos de Bolivia - (CSUTCB)." Convocatoria FLASCO 93-95. (Quito: FLASCO, 1995)

Miguel Urioste. Segunda Reforma Agraria: Campesinos, Tierra y Educacion Popular (La Paz: Talleres CEDLA, 1987).

Arturo Urquidi. El Feudalismo en America y la Reforma Agraria Boliviana. (La Paz: Libreria y Editorial "Juventud", 1990).

Gabriela Valdivia. "Agrarian Capitalism and Struggles over Hegemony in the Bolivian Lowlands." Latin American Perspectives, 37(4)(2010): 67-87.

Miguel Vargas. "Participación y consentimiento libre, previo e informado." Petropress, I6 (2011): pp.18-21.

Pablo Villegas. “Analysis de la Ley de la Revolucion Productiva.” Presentaciones CEDIB (Cochabamba: CEDIB, 2011).

Pablo Villegas. “¿Puede haber Consulta Previa entre la escopeta y las palomas?” Petropress, 22 (2011).

Jeff Webber. "Revolution against "progress": the TIPNIS struggle and class contradictions in Bolivia." International Socialism, 133 (2012).

Tony Weis. The Global Food Economy: The Battle for the future of farming (London: Zed Books, 2007): 89-120. 
Roxana Ybarnegaray de Paz. El Espiritu del Capitalismo y la Agricultura Crucena, (Editorial Atenea: La Paz, 1992).

\section{Newspaper Articles:}

W. Chipana. "El Finpro financiará a 22 sectores para asegurar alimentos y empleo." La Razon, Available online: http://www.la-razon com/economia/Finpro-financiara-sectoresasegurar-alimentos_0_1560443999.hunl (February 15, 2012).

CEDIB. "Transgenicos: ya estan en la mesa" and "[los bolivianos] se consumen alimentos geneticamente manipulados". CEDIB. "Dossier Tematico: Transgenicos 20002011." CEDIB. (Cochabamba: CEDIB, 2011)

El Cambio. "Los indígenas del Tipnis rompieron ayer con violencia un cerco de seguridad, en el noveno intento del Gobierno de dialogar " El Cambio, 25th of September (2011). Available Online : http://vww cambio.bo/noticia php?fecha=2011-09$25 \&$ idn $=55197$

El Deber. "Transgenicos: Un Conflicto mas para el Congreso." El Deber, 7 de Julio (2002).

El Opinion. "Morales propone que Bolivia sea pais libre de transgenicos,".El Opinion, 29 de Abril, (2010).

ERBOL. "Masivas movilizaciones en 9 regiones repudian violencia policial contra indígenas." Erbol, $28^{\text {th }}$ of September (2011). Available Online at:

http://www erbol com.bo/noticia.php?identificador $=2147483950162$

Gina Mendia y Guisela Lopez. "Campesinos en Contra de cultivos transgenicos.” El Deber (2005).

La Razon. Baldwin Montero. "Evo fija 3 metas para el 2025." La Razon. (La Paz, 7 de Agosto, 2012). 
